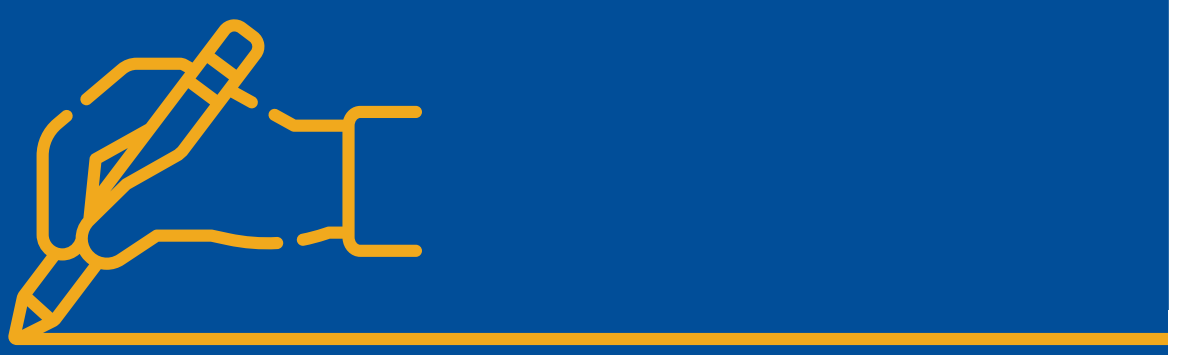

\title{
The MRC Writing, Publication and Style Guide
}

\section{Second Edition}

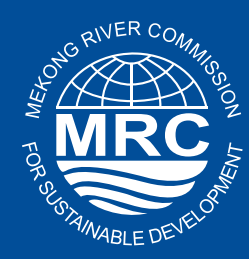

Mekong River Commission November 2021 
The MRC is funded by contributions from its Member Countries and Development Partners, including Australia, the European Union, Finland, Flanders/Belgium, France, Germany, Japan, Luxembourg, the Netherlands, New Zealand, Sweden, Switzerland, the United States of America and the World Bank. 


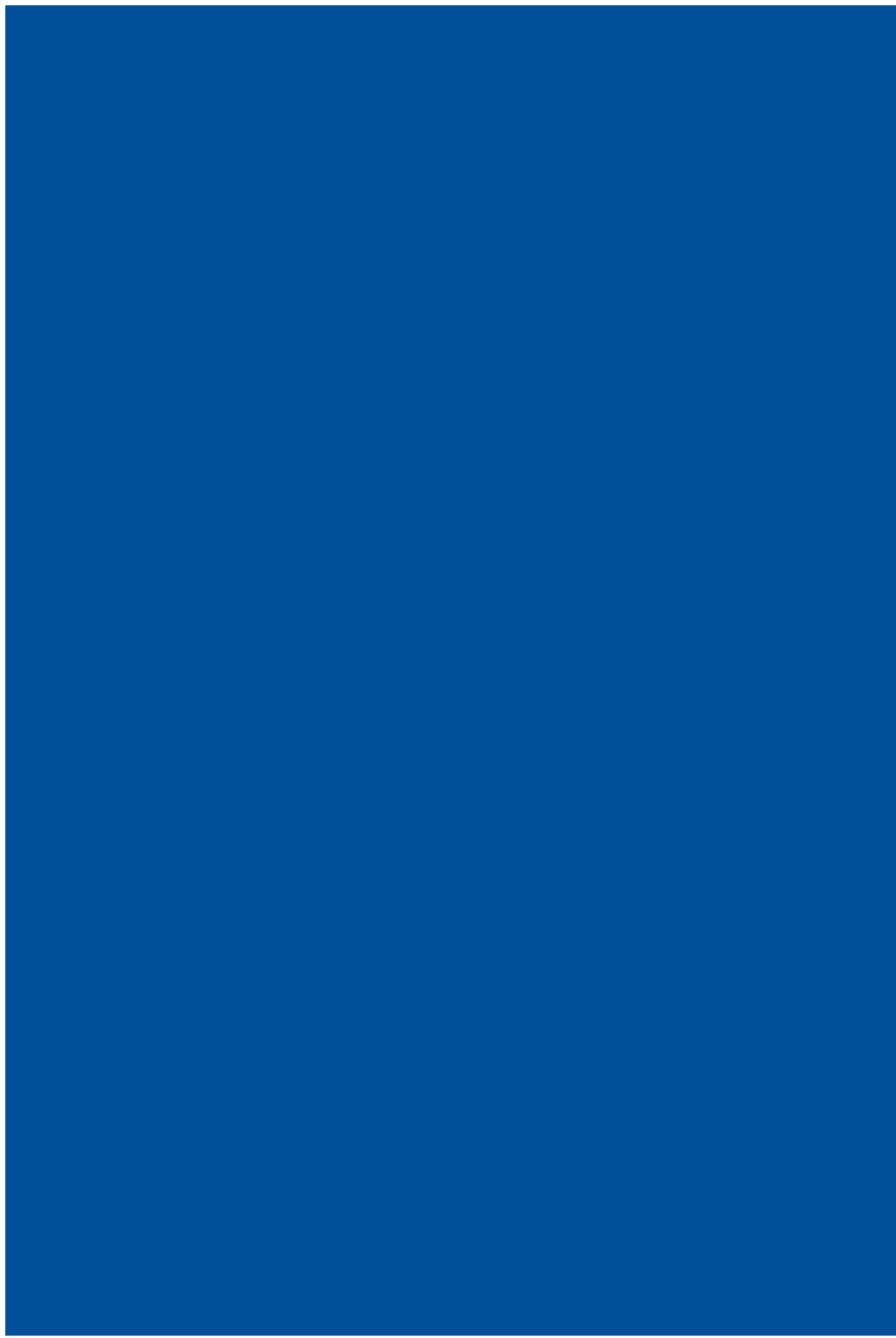


Copyright @ Mekong River Commission, 2021

First published (2007)

\section{Some rights reserved.}

This work is a product of the Mekong River Commission (MRC) Secretariat. While all efforts have been made to present accurate information, the MRC does not guarantee the accuracy of the data included in this work. The boundaries, colours, denomination and other information shown on any map in this work do not imply any judgement on the part of the MRC concerning the legal status of any territory or the endorsement or acceptance of such boundaries.

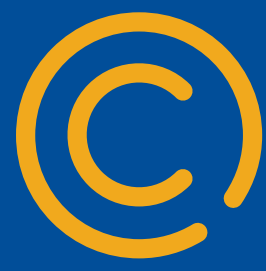

Nothing herein shall constitute or be considered to be a limitation upon or waiver of the privileges and immunities of the MRC, all of which are specifically reserved.

This publication may be reproduced, in whole or in part and in any form, for educational or non-profit purposes without special permission from the copyright holder provided that the MRC is acknowledged as the source and that notification is sent to the MRC. The MRC Secretariat would appreciate receiving a copy of any publication that uses this publication as a source. This publication cannot be used for sale or for any other commercial purpose whatsoever without permission in writing from the MRC Secretariat.

Title: The MRC writing, publication and style guide

ISSN: 2789-7664 (online), 2789-7656 (print)

DOI: $10.52107 / \mathrm{mrc} . q \times 5 y 04$

Keywords: editorial guide/style guide/writing/publication/Mekong River Commission

For bibliographic purposes, this volume may be cited as:

Mekong River Commission. (2021). The MRC writing, publication and style guide (2nd ed.). Vientiane: MRC Secretariat. https://doi.org/10.52107/mrc. qx5yo4

\section{Information on MRC publications and digital products can be found at:}

http://www.mrcmekong.org/publications/

Graphic designer: Fani Llauradó

\section{All queries on rights and licenses should be addressed to:}

Mekong River Commission

Documentation and Learning Centre

184 Fa Ngoum Road, Unit 18, Ban Sithane Neua,

Sikhottabong District, Vientiane 01000, Lao PDR

Telephone: +856-21 263263

E-mail: mrcs@mrcmekong.org | www.mrcmekong.org 


\section{Citation}

Mekong River Commission. (2021). The MRC writing, publication and style guide (2nd ed.). Vientiane: MRC Secretariat. https://doi.org/10.52107/mrc.qx5yo4

\section{Author}

\section{Management}

Dr Anoulak Kittikhoun, Chief Strategy and Partnership Officer

Technical expert

Sopheak Meas, Communications Officer for the Press 


\section{FOREWORD}

We all communicate in our own ways, using different words and phrases through different channels. But our identity as an organization remains the basis of all we write and the style we use. To be clear in our communications, our language and style must be consistent.

Having a style guide at hand as writers, editors and reviewers means that we need not face unnecessary disagreements over writing style based on our subjective opinions and preferences.

The MRC Writing, Publication and Style Guide is designed to provide a convenient source of reference. It is meant to be used by the MRC Secretariat's employees - including consultants - who are involved in disseminating information on behalf of the MRC. The Style Guide aims to improve consistency by clarifying the MRC's preferred style and highlighting good practice. It also serves as our editorial standard, aiming to resolve many of the style issues presented when producing various publications. This Style Guide, therefore, applies to all the written communications we publish and disseminate to the public.

The Guide covers a wide range of areas, including information on spelling, hyphenation, and capitalization through to gender-neutral language and referencing. It can also be used as a reference source for the preparation of other types of official, written material. 
The 2021 edition builds on our 2007 version, with modifications aimed at providing a more comprehensive Guide that is easier to use and aligned with the changing face of the MRC. Since the MRC strives to ensure uniformity and cohesion in every report we publish, the Style Guide includes an overview of the structural elements and format for MRC reports. It also includes a much fuller picture of essential elements of style. The reference section has likewise been updated to include extensive examples of in-text citations and bibliography organization. The annexes provide rich information on names of places and geographic features in the four Member Countries as well as short and official names of countries around the world.

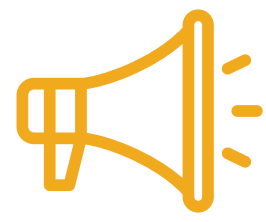

However, this Style Guide is not intended as an authoritative source for style issues. While rules and procedures are important to ensure consistency and clarity, they should not interfere with the readability of a document nor create unnecessary work for writers and editors. For this reason, some rules that were hard to enforce and did not add to quality have been eliminated. Similarly, there can be a degree of flexibility in applying the rules; nothing is carved in stone.

The Style Guide will be reviewed and updated regularly to ensure that current, relevant, and useful rules are incorporated in a timely fashion.

I hope that this MRC Writing, Publication and Style Guide will be a useful tool for all those involved in producing MRC's documentation and a valuable resource for all those communicating the MRC's story to the world at large.

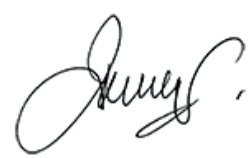

\section{An Pich Hatda}

Chief Executive Officer MRC Secretariat 


\section{CONTENTS}

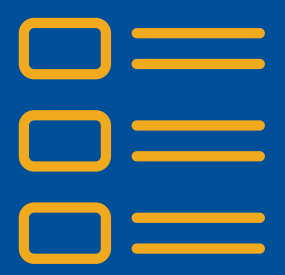




\section{Foreword}

12

Part 1: Introducction

13

1.1. Why do we need a style guide?

14 1.2. When to use this style guide?

14

1.3. The structure of the guide and how to use it

Part 2: Some writing tips

16

2.1. What is writing?

2.1.1. Before writing

2.1.2. During writing

2.1.3. After writing

2.2. Writing for a global audience

2.2.1. Using international English

2.3. MRC spelling preferences

\section{Part 3: Publication}

3.1. The structural elements of a report

3.1.1. Front page or main title page

3.1.2. Funding sources page

3.1.3. Inside title page

3.1.4. Copyright information and disclaimer

3.1.5. Citation page

3.1.6. Foreword and/or preface

3.1.7. Contents page

3.1.8. Figures page

3.1.9. Tables page

3.1.10. Boxes page

3.1.11. Abbreviations and acronyms page

3.1.12. Executive summary, or summary page

3.1.13. The main body of manuscript from the introduction to the conclusion

3.1.14. Glossary

3.1.15. Reference page or bibliography

3.1.16. Annexes section 
4.1. Abbreviations and acronyms

4.1.1. Abbreviations

4.1.2. Acronyms

\subsection{Capitalization}

4.2.1. Basic rules

4.2.2. Geographical designations and regions

\subsection{Copyright information and disclaimer}

\subsection{Countries}

4.4.1. Member Countries

4.4.2. Dialogue Partners

4.4.3. Other countries

4.4.4. Names of places and geographic features

4.5. Figures, tables and boxes
4.5.1. Figures
4.5.2. Tables
4.5.3. Boxes

4.6. Footnotes and endnotes

4.7. Formatting and layout
4.7.1. Bold
4.7.2. Italics
4.7.3. Headings and subheadings
4.7.4. Paragraphs, subparagraphs and lists
4.7.5. Spacing

4.8. Gender-neutral or inclusive language

4.8.1. Neutral or gendered nouns

4.8.2. Titles and names

4.8.3. Personal pronouns

4.9. Numbers
4.9.1. Arabic numerals
4.9.2. Cardinal numbers
4.9.3. Dates
4.9.4. Millions, billions and trillions
4.9.5. Numbers occurring together or in a series 4.9.6. Ordinal numbers
4.9.7. Ranges of numbers
4.9.8. Telephone and fax numbers
4.9.9. Time of day
4.9.10. Units of measurement 


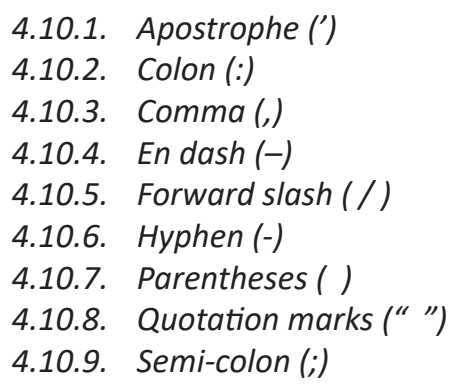

70 Part 5: References

71 5.1. Citing references within the text

73 5.2. Formatting and layout of references and bibliography entries

74 5.3. References and bibliography examples

5.3.1. Textual works

5.3.2. Data sets

5.3.3. Audio-visual media

5.3.4. Online media

90 Bibliography

91 Annexe 1: Structural elements of a report

96 Annexe 2: Other countries

103 Annexe 3: Names of places and geographic features 


\section{PART 1: INTRODUCTION}

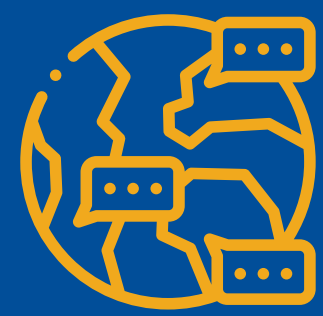

"Human languages are extremely flexible or, as some would argue, highly complex." 


\section{PART 1: INTRODUCTION}

\subsection{Why do we need a style guide?}

Human languages are extremely flexible or, as some would argue, highly complex. The Mekong River Commission (MRC) operates in a context where English is used as the international language. In the four Member Countries, at least four official languages - Khmer, Laotian, Thai, and Vietnamese - are used for daily communication.

In such a context, the MRC has adopted English as an official language for communication across its operations, products, and services. But there are variations within the English language. Styles vary. There are many ways in which a particular message can be communicated.

As an intergovernmental river basin organization, the MRC has a clear mission and a well-defined strategy. Its activities span across the four Member Countries - Cambodia, Lao PDR, Thailand and Viet Nam and involve staff of many different nationalities and backgrounds. Furthermore, although the work of the MRC covers a diverse set of sectors and activities, it has a clear identity based on the type of work that it undertakes and the governmental and administrative levels at which it operates. Therefore, it is important that all products produced by the MRC also reflect this uniform approach. It is necessary that they follow a standard style guide.

By following a style guide, the MRC can limit the variation that exists in the language that it uses, creating a uniform and consistent communication. A style guide also helps to define the organization's image that it seeks to develop and portray. It is rather like the branding of a multinational business that brings together a diverse set of activities under a unified and readily recognizable corporate identity.

This MRC Writing, Publication and Style Guide aims to provide information on style and writing conventions particular to the MRC. It contains detailed specifications of the MRC's standards for spelling, grammar, word use, punctuation, capitalization, referencing, and other aspects of document production. It also helps to ensure that all MRC publications have a consistent writing style. 


\section{4 | THE MRC WRITING, PUBLICATION \& STYLE GUIDE}

However, it should be noted that there are special cases, particularly in promotional materials, when editors may need some flexibility with regards to following these rules.

\subsection{When to use this Style Guide?}

This Guide should be consulted and used to prepare the following documents. When in doubt, authors and relevant Divisions/Offices may consult the Communications Team at the Office of the Chief Executive Officer (OCEO) for advice and clarification.

- Technical reports, papers and studies

- Management and development series

- Technical and administrative manuals and toolkits

- Conference and workshop proceedings

- Annual reports

- Strategies and work programmes/projects

\subsection{The structure of the Guide and how to use it}

The Guide contains five independent sections that can be revised, updated, and supplemented to meet user's requirements in the future. Following a short introductory section in Part 1, useful writing tips and spelling rules that the MRC has adopted are highlighted in Part 2.

Part 3 lays out the structural elements of a report that authors and editors need to follow - from the front matter to the body of the text and the reference page.

Part 4 provides greater detail on the essential elements of style. These include rules about capitalization, punctuation, figures, and the arrangement of tables and boxes. Finally, citation and reference guidance, including various examples, is provided in Part 5. 


\section{PART 2: SOME WRITING TIPS}

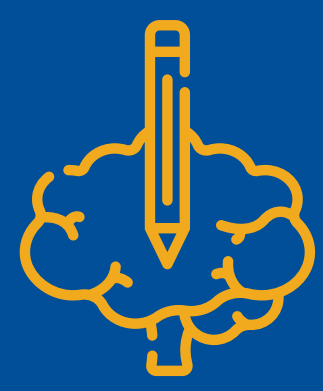

"The truth is that writing is a process of discovery that involves a series of steps, which are very often elements of a zigzag journey." 


\section{PART 2: SOME WRITING TIPS}

\subsection{What is writing?}

Many people believe, mistakenly, that writing should flow in a simple, straight line from the writer's head onto the page. But writing is seldom an easy, one-step journey in which a finished paper comes out in a first draft. The truth is that writing is a process of discovery that involves a series of steps, which are very often elements of a zigzag journey.

Writing clearly is even more important. It is also very demanding. It requires a great deal of work - from planning, organizing, and formatting to revising. Even professional writers do not sit down and write a paper automatically in one draft; rather, they have to work on it a step at a time.

This part of the Guide is intended to help authors draft and organize text so that the information presented is structured and can be easily understood and navigated by readers. The needs of the readers of MRC's documents are an important concern: simplicity, clarity and consistency are essential for effective communication in a multilingual and multicultural environment. However, this does not mean that authors have to dumb down all the technical terms for the sake of clarity. The authors can still write clearly in technical language. This is why this Guide is a very useful tool to be consulted and followed.

\subsubsection{Before writing}

Before you start writing, it is helpful to ask yourself the following questions:

- Who is going to read my paper?

- What is the purpose and what are the key messages to be conveyed?

- What content is to be included? Do I have access to all the required content?

- Have I considered the structure of the paper and prepared an outline with appropriate headings and subheadings?

- Have I followed a style guide? 


\subsubsection{During writing}

As you are writing:

- Write clearly and unambiguously, avoiding jargon.

- Use the active voice whenever possible.

- Keep sentences simple, short and relevant, ensuring that they flow smoothly one after the other.

- Present the main point of each paragraph at its beginning, then fill in the details in the rest of the paragraph.

- Use words economically, avoiding a few words when one is sufficient.

- Write one paragraph per topic, unless the topic is very long.

- Use lists/sub-paragraphs to break up the text and present information at a glance.

- Include figures, tables and boxes for illustration purposes.

\subsubsection{After writing}

Your job as a writer is not done when you have finished the writing. You will need to:

- revise critically, from a multilingual reader's point of view.

- eliminate all unnecessary and superfluous words, and ensure that sentences make sense.

- ask colleagues to read and comment.

- run any editorial tools as appropriate.

- run a spell check, remembering that MRC's spelling preferences should be used.

- ensure that you give proper citations to sources or material you refer to and list them in the reference list. Be sure you follow the APA citation style for both in-text citations and references.

\subsection{Writing for a global audience}

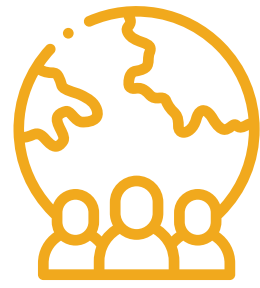

Publications from the MRC reach a diverse range of readers. Our audience is not limited to those in the Lower Mekong River Basin. There are native speakers of English and native speakers of other languages who read these materials. As authors, your job is to ensure that you communicate clearly with a host of readers from different cultural backgrounds. It is also important that you use the standard English spelling that the MRC has adopted. 
This part of the guide provides some brief directions on how to write for international readers while maintaining consistency throughout your report manuscript.

\subsubsection{Using international English}

Regardless of where you are from, as an author, your task is to write for international readers. To write for international readers, you need to adapt your writing to respect their language needs and cultural protocols. To communicate with non-native speakers, use 'international English' - a way of writing that is easily understood, culturally appropriate, and diplomatic. International English is userfriendly in terms of words, sentences, formats, and visuals.

Writing international English requires re-examine your own writing. The words, idioms, phrases, and sentences you select instinctively for American or Australian readers may not be appropriate for an audience for whom English is a second or even a third language. If you find a set of instructions accompanying your computer software package confusing, imagine how much more intimidating such a document would be for non-native speakers of English. You can eliminate such confusion by making your messages clear, straightforward, and appropriately polite for non-native readers.

Here are some basic guidelines to help you write international English:

- Use clear, easy-to-understand sentences, not rambling, complex ones. This does not mean that you should write short and simple sentences, but that you should take into account that readers will find your message easier to understand if your sentences do not exceed 15-20 words. Moreover, do not try to pack too much information in a single sentence; consider using two or more sentences instead.

- Avoid jargon, idioms (for example, "to line one's pockets"), and abbreviations (for example, "PDG") that international readers may not know. If you use an abbreviation, you need to define it at its first appearance (For more on this, see Abbreviations and acronyms.).

- Choose clear, commonly used words that unambiguously translate into the non-native speaker's language. Where possible, try to avoid flowery or pretentious ("amend" for "change") language. 
- Select visuals and icons that are free from cultural bias or that are taboo in the non-native speaker's country. (For more on this, see Figures, tables and boxes.)

- When in doubt, consult someone from the native speaker's country - a co-worker, or a member of the Communications team.

\subsection{MRC spelling preferences}

English with British spelling and usage was adopted as the umbrella language of the MRC in the early days. In particular, use: colour, not color, programme, not program (except when referring to computer software); centre, not center; metre, not meter (except when referring to a measuring device or measuring action).

The -ize and -ise endings on words (authorise and authorize) are now equally acceptable in British spelling. ${ }^{1}$ While authors are free to use any of the two versions, it is important to always be consistent.

However, do not use British spelling if the organization uses American spelling (WorldFish Center) or the spelling of citations and references.

Set the spell checker in MS Word to English (UK), but always read through your text carefully since the spell checker will only highlight misspelt words, not wrong usage. 


\section{PART 3: PUBLICATION}

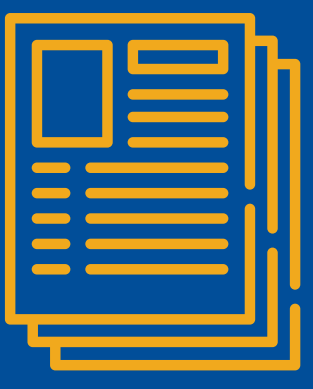

"Authors are responsible for including the correct structural elements in the draft report." 


\section{PART 3: PUBLICATION}

Reports published by the MRC must follow one standard structure, from the title page to the annexe. This is part of the corporate image the Commission has sought to build. The MRC requires that any report made available to the public strictly follow this structure.

This section of the guide will help authors outline their manuscripts correctly at the beginning of the process.

\subsection{The structural elements of a report}

When preparing a manuscript, authors are responsible for including the correct structural elements where appropriate. When included, these elements appear in the following order:

- Frontpage or main title page

- Funding sources page

- Inside title page

- Copyright information and disclaimer (imprint page)

- Citation page (information on authorship and contribution)

- Foreword and/or Preface (if any)

- Contents page (table of contents)

- Figures page (list of figures)

- Tables page (list of tables)

- Boxes page (list of boxes)

- Abbreviations and acronyms page

- Executive summary or summary page

- Main body of text from the introduction to conclusion

- Glossary (add as an annexe or a stand-alone chapter if there are no annexes)

- References page or bibliography

- Annexes

For detailed text layout settings, such as font, size, and pagination, see Formatting and layout.

${ }^{2}$ Go to this link to download the complete layout guide: https://bit.ly/3Gpkbkg
A sample of the complete layout is available for download separately here $^{2}$ and is annexed to this Style Guide (see Annexe 1). 


\section{2 | THE MRC WRITING, PUBLICATION \& STYLE GUIDE}

\subsubsection{Frontpage or main title page}

The title of your report must be clearly identified on the very first page of your report - the front page or main title page. This should be written in the middle of the page, bold, and aligned left, with $\mathbf{2 5}$ pt. font size. The subtitle, if there is one, should be written below the main title, in italics and with $\mathbf{2 0}$ pt. font size.

Each word should be capitalized, except for prepositions (such as 'of', 'on', 'for', and so forth). Avoid effects such as shading, WordArt, etc.

Near the very bottom of the page, there will be the month and year (for example, May 2017) to indicate the publication date of the report. See an example in Annexe 1 for the front page.

Please be mindful when you select a title for your report to ensure that it represents the contents and is attractive to readers. Therefore, you should:

- be sure to pick a title that reflects and/or provides a meaningful description of the report's content.

- be sure to select a title that, overall, covers all the specific objectives aimed for in the report.

- be sure to select a title that is short, concise and enticing so that it attracts readers. This requires time in order to abbreviate long titles (more than 20 words).

\subsubsection{Funding sources page}

The $M R C$ receives funding contributions from the Member Countries and multiple Development Partners, and their support should be fully acknowledged. While authors are not to worry about who the donors are, they should leave a blank funding sources page right after the title page. See an example in Annexe 1.

\subsubsection{Inside title page}

Authors should also include the title of their manuscript on an inside title page in much the same way as on the front page. However, the authors will need to include the MRC logo on the top in the centre of the paper above the title. See an example in Annexe 1.

The MRC logo in different formats is available at: https://bit. ly/3GmY3qF 


\subsubsection{Copyright information and disclaimer (imprint page)}

In the published version of your manuscript, there will be an MRC standard copyright information and disclaimer page or an imprint page - the page that appears on the back of the front page that contains everything readers need to know about who wrote the document, who the publisher is, how they can contact the MRC, what the ISBN or ISSN is, and who owns the copyright, etc.

While you do not need to worry about arranging this page in your manuscript, you should know that the citation of your report will be under a corporate name - the MRC.

\subsubsection{Citation page (information on authorship and contribution)}

The MRC Secretariat publishes materials under one name - the MRC. However, substantive management and technical input should be mentioned and acknowledged using the standard method but not in a generally descriptive way as in a book.

Follow the following order when preparing authorship information and contribution:

\section{CITATION}

Mekong River Commission. (Year). Title of the report. Vientiane: MRC Secretariat.

\section{AUTHORS}

Project management (if any):

$\mathrm{Mr} / \mathrm{Ms} / \mathrm{Dr}$ First name Family name, Title; Mr/Ms/Dr First name Family name

Technical experts (if any):

MRC Secretariat's technical experts (if any)

$\mathrm{Mr} / \mathrm{Ms} / \mathrm{Dr}$ First name Family name, Title; Mr/Ms/Dr First name Family name

National technical experts (if any)

$\mathrm{Mr} / \mathrm{Ms} / \mathrm{Dr}$ First name Family name, Title, Workplace, Country; Mr/ Ms/Dr First name family name, Title, Workplace, Country

International technical experts (if any)

$\mathrm{Mr} / \mathrm{Ms} / \mathrm{Dr}$ First name Family name, Title, Workplace, Country; Mr/ Ms/Dr First name Family name, Title, Workplace, Country 


\section{4 | THE MRC WRITING, PUBLICATION \& STYLE GUIDE}

See Annexe 1 for an example.

\subsubsection{Foreword and/or preface (if any)}

A foreword is usually a short piece of writing, no longer than a couple of pages, at times placed at the beginning of a book or other literature. The foreword is not necessary for most technical reports produced by the MRC; however, it is generally found in manuals or guidelines that the Commission produces.

As a general guideline, any strategy, manual, or document that the MRC Council or Joint Committee approves should include a foreword by the Chairperson of the Council or the Joint Committee. Anything major, such as technical reports, studies or manuals that the MRC Secretariat produces but that are not approved by the Council or the Joint Committee, should include a foreword by the CEO. Consult the Communications Team at the OCEO if you are not sure whether you need one for your manuscript.

It is worth noting that forewords are written by someone other than the author. In most cases, they are, depending on the type of work, written either by the CEO of the MRC Secretariat, the Chairperson of the MRC Joint Committee, or the Chairperson of the MRC Council.

If you need a foreword, consider the following principles:

- The content should introduce the author or work to readers, tell readers why they should read the report or book, and give credibility to the author and/or book.

- It often tells of some interaction between the writer of the foreword and the book's primary author or about the book's or report's content.

- Information essential to the main text is generally placed in a set of explanatory notes, or perhaps in an introduction, rather than in the foreword or in a preface.

- It is important to strike the same tone as the rest of the book or report. Avoid writing a witty, humorous foreword if the book is more serious, and vice versa.

Unlike a preface, a foreword is always signed. If the report includes both a foreword and a preface, the foreword comes first. 
the report or book, you should choose a preface.

A preface is an introduction to a report written by the work's author. Consult the Communications team should you need a preface or a foreword.

If you need the former, you should try to achieve the following:

- Spark curiosity about your content and draw readers in. Your job here is to make that the potential reader will want to read more.

- Speak directly about the purpose, creation, and/or importance of your work: How did your work come about? What was the main point you were seeking to address? Why is that important to your readers?

- Also, explain the who, when, and where.

- Provide a framework for what's to follow - the hooks on which to hang the pegs of story details.

- Acknowledge all those who have contributed to realizing the work.

\subsubsection{Contents page (table of contents)}

Your report must include a contents page containing all headings and sub-headings of all the chapters or sections.

It usually includes the titles or descriptions of first-level headings (chapters in longer works) and often includes second-level headings (sections or A-heads) within the chapters, and occasionally even includes third-level headings (subsections or B-heads). The depth of detail in tables of content strongly depends on the length of the work, with longer works including less information.

The pages starting from the foreword and/or preface to acknowledgements, contents, figures, tables, boxes, and abbreviations and acronyms need to be paginated in lower-case, roman numerals (for example, i, ii, iii and so on).

The sequencing numerals (such as 1, 2, 3 and so on) should start from the executive summary until the annexe section.

A sample of the whole layout is available for download separately here and is annexed to this style guide (see Annexe 1). 


\section{6 | THE MRC WRITING, PUBLICATION \& STYLE GUIDE}

\subsubsection{Figures page (list of figures)}

All figures and their captions, together with their page numbers, must be presented on this page. Readers often review them independently of other sections. Figures, like other visuals, must be simple and easy to understand at a glance and should give useful information that supplements (but does not repeat) the text.

Authors are responsible for providing good quality, high-resolution editable files of the illustrations used in their manuscript (preferably in .eps or .ai format).

\subsubsection{Tables page (list of tables)}

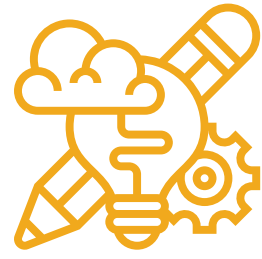

A list of tables is a reference tool that allows readers to quickly and easily navigate to data in a report. Readers often review them independently of other sections of a report. Like figures and other visuals, tables must be simple and easy to understand at a glance and should give useful information that supplements (but does not repeat) the text.

\subsubsection{Boxes page (list of boxes)}

Boxes generally contain information that supports the points given in the main text. They are inserted like figures or tables and are treated in the same way. Unlike other visuals, boxes can be used for case studies or to provide additional information.

If boxes are provided in an image file, authors are responsible for providing good quality, high-resolution editable files of the illustrations used in their manuscript (preferably in .eps or .ai format).

For figures, tables and boxes taken from other sources covered by copyright, permission for reproduction must be obtained from the copyright holder prior to inclusion in the manuscript. In addition, all sources must be acknowledged.

See Figures, tables and boxes for more information.

\subsubsection{Abbreviations and acronyms page}

Many abbreviations and acronyms have become common to the MRC over the past 25 years. They could even be used to form a whole sentence that is only understandable to the MRC community! But this is not the purpose of communication. 
Many acronyms and abbreviations used to simplify communication among experts in a specific field are puzzling to non-specialist readers. Thus, they should be used sparingly and avoided wherever possible. They should not be used when they occur only once or twice in a manuscript.

When unavoidable, insert the abbreviation or acronym in parentheses after the first mention of the (full) term and then use the abbreviation or acronym consistently thereafter.

Abbreviations and acronyms should be spelt out in full titles and headings and should not be followed by the abbreviation in parentheses. As a general rule, they should be spelt out at the beginning of sentences and redefined at first mention in each annexe.

Authors are to reserve a space to include all the abbreviations and acronyms used throughout manuscripts.

See Abbreviations and acronyms for more detail.

\subsubsection{Executive summary, or summary page}

Authors should provide an overview of the main points of their report in the form of an executive summary.

The executive summary is a concise version of the larger manuscript, written for individuals (for example, busy reporters, non-specialist readers, and so on) who may not have time to review the entire report. The reader should have sufficient and critical information to make a decision based only on reading the executive summary.

A typical executive summary should have the following features:

- It summarizes the key points of the larger report.

- It restates the purpose of the report by highlighting its major points and describing any results, conclusions, or recommendations from the report.

- It includes enough information so the reader can understand what is discussed in the full report without having to read it in its entirety.

- It is usually 1-4 pages long (although executive summary lengths vary according to the length of the larger document). As a rule of 
thumb, executive summaries are $\mathbf{1 0 \%}$ of the entire document or less.

Remember that readers often do not have much time, so their attention must be captured quickly to convince them to keep reading. Also, recall that an executive summary is not:

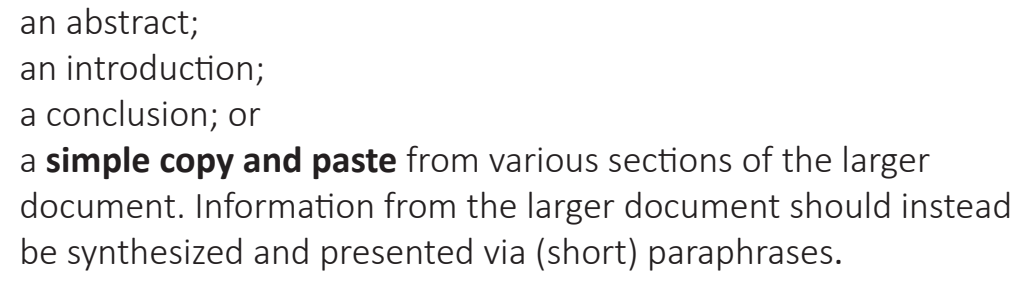

\subsubsection{The main body of a manuscript, from the introduction to the conclusion}

The main body of your manuscript is where you discuss your material. The facts and evidence you have gathered should be analysed and discussed with specific reference to the problem or issue.

The body can be subdivided into parts, sections and/or subsections. If your discussion section is lengthy, you need to divide it into section headings. Your points should be grouped and arranged in an order that is logical and easy to follow. You should use headings and subheadings to create a clear structure for your material. You should also use bullet points to present a series of points in an easy-to-follow list.

As with the whole manuscript, all sources used should be acknowledged and correctly referenced. Hence, authors are advised to be alert to plagiarism. If material from other publications is to be used, seek permission from the copyright holder before inserting it and acknowledge the source. Nevertheless, permission is not needed for publications of the MRC and national line agencies, except for commissioned photographs.

\subsubsection{Glossary (if any, add as an annexe or a stand-alone chapter if there is no annexe)}

Authors may wish to provide an alphabetical list of technical terms with a brief, clear description of each term. A glossary - also referred to as a vocabulary - includes technical, uncommon, or specialized terms that are not widely known to the public. 
If provided, authors should be mindful to include only those terms that could add some useful knowledge to readers or clarify terms.

\subsubsection{Reference page or bibliography}

The MRC follows the American Psychological Association (APA) Style Guide for citations and references, with a few slight modifications. Authors are responsible for ensuring that all references and bibliographical items are accurate, complete, and correct. Likewise, editors ensure that references follow the APA Style Guide but do not check their accuracy.

All references cited in the text must be given in the references section under the heading 'References', which should contain only those mentioned in the text.

If required, a 'Bibliography' may contain references relevant to the subject matter and recommended for further reading but not mentioned in the text.

The references and/or bibliography are normally placed at the end of a publication, after the glossary (if any) and before the annexe section.

Personal communications (such as emails, personal interviews, telephone conversations, and so on) should not be referred to in either the references or the bibliography chapters.

All entries should follow the style and format given in the references and bibliography section (see References).

Authors are strongly recommended to use a bibliography software package, such as EndNote, Mendeley Reference Manager, or Zotero, when preparing references to assist with in-text citation and reference management.

More information about the APA can be found here:

https://apastyle.apa.org

\subsubsection{Annexes section}

If additional information cannot be discussed in greater detail in the main report, the authors should provide it as an annexe. The annexe should follow the same formatting, pagination, margin and illustration requirements. 


\section{PART 4: ESSENTIAL ELEMENTS OF STYLE}

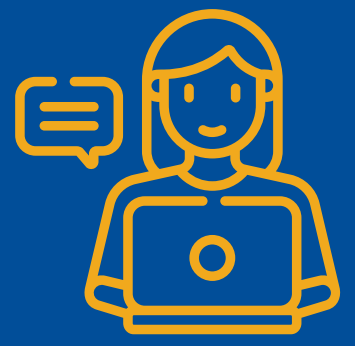

"While authors have great flexibility in choosing how they express a concept, they should recall that the point of good writing is simple, clear, concise, and engaging." 


\section{PART 4: ESSENTIAL ELEMENTS OF STYLE}

Authors' writing styles can differ from each other. A writing style is how we express thought in a language that characterizes an individual or institution. Beyond the essential elements of spelling, grammar, and punctuation, the writing style is the choice of words, sentence structure, and paragraph structure, all of which are used to convey meaning effectively.

While authors have great flexibility in choosing how they express a concept, they should recall that the point of good writing style is simple, clear, concise, and engaging. It is much easier for readers to concentrate on content when a clear and consistent style is used.

Thus, this part of the guide provides authors and editors with MRC editorial practices, arranged alphabetically, to be followed in preparing manuscripts

\subsection{Abbreviations and acronyms}

Many acronyms and abbreviations used to simplify communication among experts in a specific field are puzzling to readers who are nonspecialists. Thus, abbreviations and acronyms should be used sparingly and avoided wherever possible; they should not be used when they occur only once or twice in a manuscript.

When unavoidable, insert the abbreviation or acronym in parentheses after the first mention of the (full) term and then use the abbreviation or acronym consistently after that. When the entity referred to is better known by the abbreviation or acronym, it may be preferable to include it in parentheses after the full name, even if it occurs only once.

Abbreviations and acronyms should be spelt out in full titles and headings and should not be followed by the abbreviation in parentheses. As a general rule, they should be spelt out at the beginning of sentences and redefined at first mention in each annexe. 
However, some abbreviations and/or acronyms for technical terms - such as GDP, GPS, HIV, AIDS and DNA - and acronyms related to communication technology - such as CD, DVD, HTML, SMS, URL and $\mathrm{XML}$ - are now so widely used that spelling them out in full is unnecessary.

MRC should always be spelt out in full at its first mention and abbreviated after that. But in headings, this is not necessary.

Always use an article before an abbreviation/acronym: "The MRC is the only treaty-based, inter-governmental, river basin organization ..." not "MRC is the ...".

A list of abbreviations and/or acronyms is required in all MRC publications.

Chemical formulae (for example, $\mathrm{CO}_{2}, \mathrm{CH}_{4}, \mathrm{H}_{2} \mathrm{O}, \mathrm{O}_{2}, \mathrm{~N}_{2}$ ) should be treated as abbreviations/acronyms and spelt out at first mention in the text and the beginning of sentences.

\subsubsection{Abbreviations}

Abbreviations may be used in figures, tables or boxes where space is limited, and a key should be provided for all abbreviations not previously defined in the text.

Avoid the use of, e.g., i.e. and etc. whenever possible, except in lists and tables. They can be replaced as follows:

e.g.: for example, for instance, such as

i.e.: that is

etc.: and the like, and so forth, except in lists. Where used, 'etc.' is preceded and followed by a comma when it is the final item of a series: hydrology and hydraulics, sediments, water quality, fish, etc., are monitoring disciplines.

'Etc.' should not be used with 'for example' (incorrect: for example, A, B, C, etc.). Never use 'and etc.' Do not use a comma after 'e.g.' and 'i.e.'

'Mr', 'Ms' and 'Dr' do not take a period or full stop.

\section{CURRENCIES}

The currency abbreviation or symbol precedes the amount of money (not in a closed space): EUR 50,000, USD 40,000. The currency name 
written in full follows the figure:

- USD 50,000

- EUR 20,000

- KHR 100,000 or 100,000 Riel (Khmer Riel)

- $\operatorname{LAK} 100,000$ or 100,000 Kip (Lao Kip)

- THB 100,000 or 100,000 Baht (Thai Baht)

- VND 100,000 or 100,000 Dong (Vietnamese Dong)

Always use USD, not US\$, to refer to American dollars.

\subsubsection{Acronyms}

Like abbreviations, acronyms may be used in figures, tables or boxes where space is limited, and a list of acronyms should be provided (below the Table, Figure, and Box) for all acronyms not previously defined in the text.

Do not use periods or full stops with acronyms.

\subsection{Capitalization}

\subsubsection{Basic rules}

Do not overuse initial capitals. They should be used sparingly and for:

- the first word of a sentence;

- the first word (and words normally capitalized) in titles, headings and subheadings, tables and figures;

- the first word of a sub-paragraph or item on a list;

- proper nouns, adjectives and recognized geographical names;

- all words in the titles of books, periodicals, and publications, except articles, conjunctions and prepositions:

The MRC Hydropower Development Guidelines: Guidelines for Hydropower Environmental Impact Mitigation and Risk Management in the Lower Mekong Mainstream and Tributaries

- The first element of hyphenated words in titles:

Integrated Water Resources Management-based Basin Development Strategy 2016-2020 for the Lower Mekong Basin 


\section{4 | THE MRC WRITING, PUBLICATION \& STYLE GUIDE}

- Capitalize the second element only if it is a proper noun or adjective or a word normally capitalized:

Simultaneous interpretation will be provided for non-English speaking delegations

Non-MRC Member Countries

- Official titles of persons, Councils, Committees, Secretariat Divisions, organizations, and institutions.

- Titles of MRC bodies, specific positions, officials and their offices:

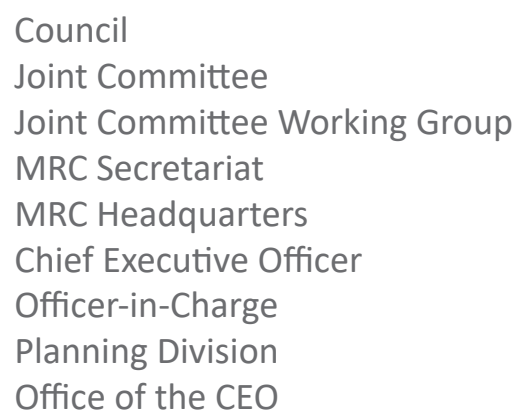

- When referring to $\mathbf{M R C}$ regulations in general, use initial capitals but do not use italics.

\section{MRC Education Grant \\ Travel Authorization}

- Programme or Project, when referring to an MRC Programme or Project, respectively.

- Chairperson or Chair (not chairman or chairwoman); Co-Chairperson or Co-Chair; Vice-Chairperson or Vice-Chair.

- Member Country, when referring to a country or member of the MRC (for example, Cambodia is a Member Country of the $\mathrm{MRC})$.

- Tropical storms, hurricanes, cyclones, typhoons and their names (italicized).

Typhoon Haiyan

Cyclone Nargis

\section{Do not use capital letters for the following:}

- Continent: the African continent 
- Hemisphere: northern, southern, eastern and western hemisphere

\subsubsection{Geographical designations and regions}

North, South, East and West are capitalized only when they are used as proper nouns or when they are part of the name of an area, a political division or concept:

the Middle East, South-South cooperation

Southeast Asia (not South-East)

the North Pole, the South Pole (but poles in general)

Adjectives and nouns derived from the cardinal points are not capitalized unless they are part of a proper name:

northern Thailand

southern Lao PDR

but South Australia

Do not capitalize a generic term such as city, country, state, or province when it precedes the proper noun or stands alone unless it is used in a corporate/collective sense:

No flash flood events were detected in Hoa Binh province of Viet Nam.

but

The report, commissioned by the Authority of Vientiane Capital, offers what appears to be a 'promising future of clean city'.

Do not capitalize a generic term unless it is part of a geographical name:

The Xe Bang Fai and Nam Song rivers, but Lake Victoria, the Blue Nile

\section{DIRECTION}

Do not use capital letters for points of the compass if they indicate direction:

a north wind, south-westerly winds

to fly south, eastward

true north 


\section{6 | THE MRC WRITING, PUBLICATION \& STYLE GUIDE}

\subsection{Copyright information and disclaimer}

Page iv of the front matter of each publication made available to the public should include the following information and disclaimers (more information is available at the MRC Publication Guidelines).

FOR APPROVED STRATEGY, PLAN, PROCEDURES AND GUIDELINES

(C) Mekong River Commission, 20xx

First published (20xx)

Some rights reserved.

This work is an approved product of the Mekong River Commission (MRC) and reflects the collective views of the Commission and its Member Countries. While all efforts are made to present accurate information, the MRC does not guarantee the accuracy of the data included in this work. The boundaries, colours, denomination, and other information shown on any map in this work do not imply any judgment on the part of the MRC concerning the legal status of any territory or the endorsement or acceptance of such boundaries.

Nothing herein shall constitute or be considered to be a limitation upon or waiver of the privileges and immunities of the MRC, all of which are specifically reserved.

This publication may be reproduced, in whole or in part and in any form, for educational or non-profit purposes without special permission from the copyright holder, provided that acknowledgement of the source is made and that notification is sent to the MRC. The MRC Secretariat would appreciate receiving a copy of any publication that uses this publication as a source. This publication cannot be used for sale or for any other commercial purpose whatsoever without permission in writing from the MRC Secretariat.

Title: Full title, written in a straight line without italics, bold or underline: Capitalize only the first word and proper nouns.

ISSN or ISBN:

Mekong River Commission

Keywords: (up to 5 words/each word separated with a forward slash/ not a comma) 
For bibliographic purposes, this volume may be cited as:

Mekong River Commission. (year written in brackets like this). Title in italics: Capitalize only the first word and proper nouns. Vientiane as the published location: MRC Secretariat as the publisher.

Information on the MRC publications and digital products can be found at http://www.mrcmekong.org/publications.

Cover photo: Full name of the photographer/MRC (if any)

Editor: Full name of the editor (if any)

Graphic designer: Full name of the designer (if any)

All queries on rights and licenses should be addressed to:

Mekong River Commission Secretariat

Documentation and Learning Centre

184 Fa Ngoum Road, Unit 18, Ban Sithane Neua, Sikhottabong District, Vientiane 01000, Lao PDR

Tel: +856-21263263 | E-mail: mrcs@mrcmekong.org

\section{FOR OTHER DOCUMENTS (ASSESSMENT, CATCH AND CULTURE, MEKONGDEVELOPMENTSERIES, PROCEEDINGS, REPORT,STUDY,AND TECHNICAL REPORT AND PAPER)}

(C) Mekong River Commission, 20xx

First published (20xx)

Some rights reserved.

This work is a product of the Mekong River Commission (MRC) Secretariat. While all efforts have been made to present accurate information, the MRC does not guarantee the accuracy of the data included in this work. The boundaries, colours, denomination, and other information shown on any map in this work do not imply any judgment on the part of the MRC concerning the legal status of any territory or the endorsement or acceptance of such boundaries.

Nothing herein shall constitute or be considered to be a limitation upon or waiver of the privileges and immunities of the MRC, all of which are specifically reserved.

This publication may be reproduced, in whole or in part and in any form, for educational or non-profit purposes without special permission from the copyright holder provided that the MRC is acknowledged as the source and that notification is sent to the MRC. The MRC Secretariat would appreciate receiving a copy of any 
publication that uses this publication as a source. This publication cannot be used for sale or for any other commercial purpose whatsoever without permission in writing from the MRC Secretariat.

Title: Full title, written in a straight line without italics, bold or underline: Capitalize only the first word and proper nouns.

ISSN or ISBN:

Mekong River Commission

Keywords: (up to 5 words/each word separated with a forward slash/ not a comma)

For bibliographic purposes, this volume may be cited as:

Mekong River Commission. (year written in brackets like this). Title in italics: Capitalize only the first word and proper nouns. Vientiane as the published location: MRC Secretariat as the publisher.

Information on the MRC publications and digital products can be found at http://www.mrcmekong.org/publications.

Cover photo: Full name of the photographer/MRC (if any)

Editor: Full name of the editor (if any)

Graphic designer: Full name of the designer (if any)

All queries on rights and licenses should be addressed to:

Mekong River Commission Secretariat

Documentation and Learning Centre

184 Fa Ngoum Road, Unit 18, Ban Sithane Neua, Sikhottabong District, Vientiane 01000, Lao PDR

Tel: +856-21263263 | E-mail: mrcs@mrcmekong.org

Page $v$ of the front matter of this 'other document type' also includes full authorship information, albeit not for citation, as the following (listed separately on a single page):

\section{CITATION}

Mekong River Commission. (year written in brackets like this). Title in italics: Capitalize only the first word and proper nouns. Vientiane as the place of publication: MRC Secretariat as the publisher.

\section{AUTHORS}

Project management (if any):

$\mathrm{Mr} / \mathrm{Ms} / \mathrm{Dr}$ first name family name, Title; Mr/Ms/Dr first name family name 
Technical experts (if any):

MRC Secretariat's technical experts (if any)

$\mathrm{Mr} / \mathrm{Ms} / \mathrm{Dr}$ First name Family name, Title; Mr/Ms/Dr First name Family name

National technical experts (if any)

$\mathrm{Mr} / \mathrm{Ms} / \mathrm{Dr}$ First name Family name, Title, Workplace, Country; Mr/Ms/ Dr First name Family name, Title, Workplace, Country

International technical experts (if any)

$\mathrm{Mr} / \mathrm{Ms} / \mathrm{Dr}$ First name Family name, Title, Workplace, Country; Mr/Ms/ Dr First name Family name, Title, Workplace, Country

\subsection{Countries}

The MRC uses the short form of country names in its publications and news, while the formal name is generally used in legal texts, including Declarations and MOU.

\subsubsection{Member Countries}

Although it is common to use 'States' in place of 'Countries', the MRC adopts the use of 'Member Countries' in capitals when referring to the four Members.

The four Member Countries of the MRC are spelt as follows:

\section{Cambodia, or the Kingdom of Cambodia}

Lao PDR, or Lao People's Democratic Republic

Thailand, or the Kingdom of Thailand

Viet Nam, or the Socialist Republic of Viet Nam

In general communications, including in press statements and social media posts, it is acceptable to use Laos and Vietnam instead of Lao PDR and Viet Nam, respectively.

List the countries alphabetically unless there is a good reason to do otherwise, for example, when referring to the course of the Mekong or ranking the countries for a specific reason, such as in the order of population density:

The MRC Member Countries - Cambodia, Lao PDR, Thailand, and Viet Nam - adopted the Drought Management Strategy last week in order to address the widespread drought currently hitting the four countries. 
The Mekong flows through Lao PDR, Thailand, Cambodia, and Viet Nam in the Lower Mekong River Basin.

\subsubsection{Dialogue Partners}

The MRC Dialogue Partners are:

China, or the People's Republic of China

Myanmar (not Burma), or the Union of Myanmar

Dialogue Partners are capitalized, as are Member Countries.

\subsubsection{Other countries}

The MRC has partners across the globe, and it is important that authors correctly spell out these partners and their countries in the manuscript. Annexe 2 lists these countries in alphabetical order, including their short and official names.

\subsubsection{Names of places and geographic features}

Authors are advised to check and spell out correctly the names of cities, provinces, rivers and catchments in the four Member Countries if used in their manuscript.

The spelling of some of these names varies, for example, Xayabouri, Xayabuli, or Xayaburi. Consult Annexe 3 of this Guide for a full list of names of these places and geographic features.

\subsection{Figures, tables and boxes}

Authors are responsible for providing good quality, high-resolution, editable files of the illustrations used in their manuscripts.

Figures and tables must be simple and easy to understand at a glance. They should give useful information that supplements (but does not repeat) the text. Consideration should be given to their presentation (for example, several short tables may be easier to understand than one complicated table), and they should use terminology consistent with the text. Figures can convey a message, tables can be used to convey data, and boxes can be used for case studies or to provide additional information.

For all figures, tables, and boxes taken from other sources covered by copyright, permission for reproduction must be obtained from the 
copyright holder prior to inclusion in the manuscript. In addition, all sources must be acknowledged.

In all publications, except for public information material, figures, tables, and boxes must be mentioned in the text before they appear (for example, see Figure 1, Table 1 shows, Box 1 illustrates).

If there is only one figure, table or box, it should not be numbered but referred to in the text as 'see the figure/table/box'. If the figure, table or box is split into parts, then these should be labelled (a), (b), (c), etc., and referred to as, for example, 'see Figure 1(a)'. Figures, tables and boxes should be placed as close as possible to where they are first mentioned and must be numbered separately and consecutively.

ABBREVIATIONS: Do not use abbreviations unless they are unavoidable; when necessary, explain those that have not previously been defined in the text in a key.

CAPITALIZATION: Capitalize only the first word and proper nouns of information included in figures, tables or boxes.

CAPTIONS: Keep titles/captions of figures, tables and boxes as short and clear as possible; however, they should accurately convey the information therein. A period/full stop should be placed after the number preceding the title: Figure 1., Table 1., Box 1. There should be no separation between the figure and its number (they all must stay in the same line.).

All captions are not bold, but they are centred on the page. However, Figure/Table/Box and its number are bold.

FONT SIZE AND TYPE: The font size should be 1 pt. smaller than that used in the main text. The font type should be the same as in the main text.

FOOTNOTES: Use 1, 2, 3 (not a, b, c or asterisks) and number footnotes separately in each figure or table, starting from 1.

PUNCTUATION: Whether the titles/captions of the figures, tables or boxes are complete or incomplete sentences, a period/full stop must NOT be used.

SPACING: Insert two lines between the text and the bottom or top of the figureor table; this should be applied consistently throughout.

Specific guidance on the stand-alone elements is provided in the following sections. 


\subsubsection{Figures}

CAPTION: Figure's captions must be written below the figure and aligned in the centre. No period or full stop should be used, regardless of whether the caption is a complete or incomplete sentence. The figure and its number are bold, while the description or caption is not.

SOURCE: If the figure has to be credited, the source should be placed below the caption in a smaller font or within parentheses at the end of the caption. Whichever option you use, use one and use it consistently.

When the source is placed below the caption, the word Source should be italicized (not bold) and left-aligned.

Examples are provided below:

\section{Basin Monitoring}

Status \& Trend

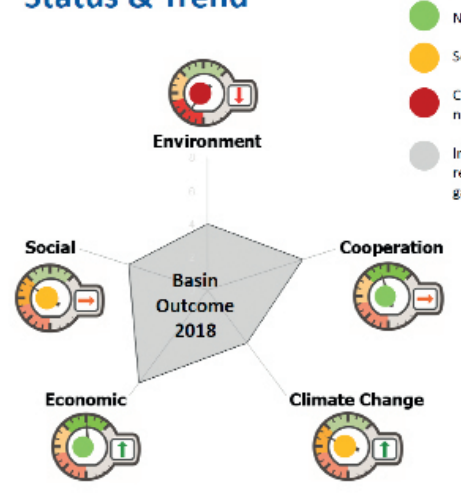

Status aps

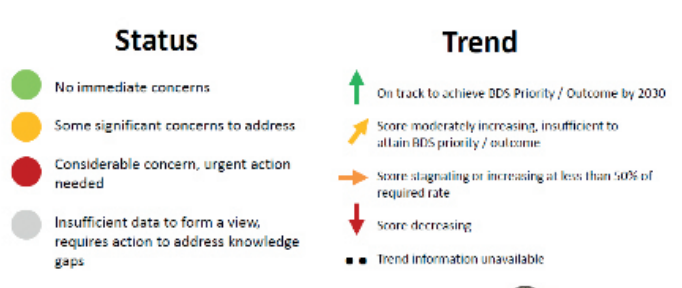

Figure 1. Sample representation of the MRC's dashboard for monitoring the status and trends in conditions across the basin

(Source: MRC, 2020) 


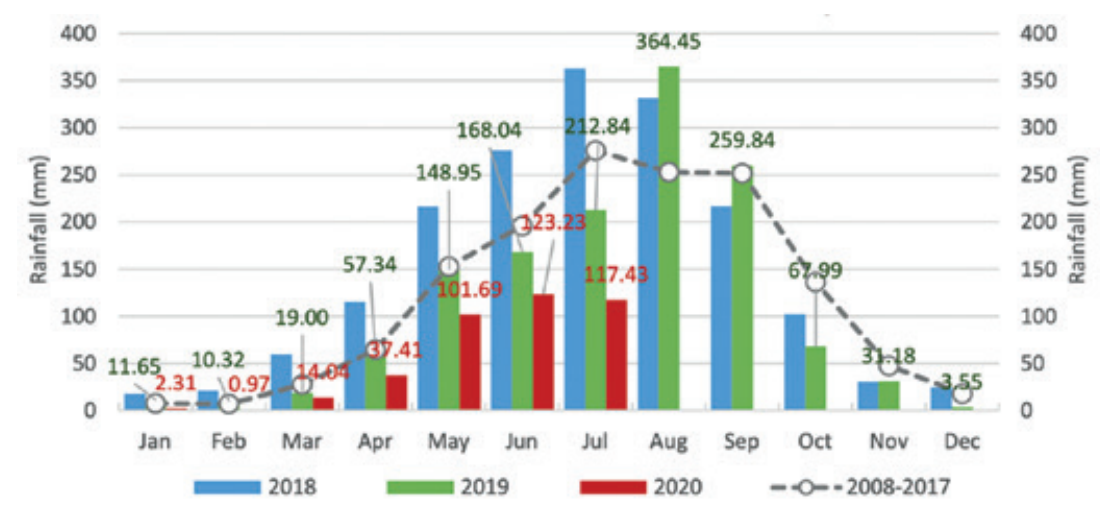

Figure 5.2. Overall monthly rainfall of 2018-2020 over the Lower Mekong Basin compared to the long-term condition of 2008-2017

Source: MRC (2020)

\subsubsection{Tables}

CAPTION: Table captions must be written above the figure and aligned in the centre. No period or full stop should be used, regardless of whether the caption is a complete or incomplete sentence. The table figure and its number are bold, while the description or caption is not.

TABLE NOTE: If there is a note to the table, use either a num bered note, an asterisk, or a non-number noted (choose one and use it consistently throughout if there is more than one note to the table). Place such a note below the table but be fore the source.

HEADING: The heading of the table should be left-aligned at the top of the columns. It should be bold but not italics. If units (for example, USD) apply to all entries in a column or row, place the units (in parentheses) in the column or row heading.

LINE: Insert horizontal lines before and after headings; draw one line at the bottom of the table. Use other horizontal lines and vertical lines only if the table is impossible to read with out them.

PUNCTUATION: Use punctuation for texts inside the table if the sentence is complete. 
SOURCE: Place the source below the table, after the note to the table. Italicize the word 'Source'.

Examples are provided below:

Table 2.5. Summary of sediment transport and geomorphic risks associated with the development and management of hydropower

\begin{tabular}{|c|c|}
\hline Change & Key risks, impacts and vulnerabilities \\
\hline \multicolumn{2}{|l|}{ Annual/inter-annual changes to flow } \\
\hline \multirow[t]{2}{*}{$\begin{array}{l}\text { Changes in seasonality and continuous uniform } \\
\text { release }\end{array}$} & $\begin{array}{l}\text { Water logging and loss of vegetation leading to } \\
\text { increased bank erosion Increased erosion due } \\
\text { to increased scour (bed incision, bank erosion) }\end{array}$ \\
\hline & $\begin{array}{l}\text { Winnowing of smaller sediment leading to bed } \\
\text { armouring and reduction in downstream } \\
\text { sediment supply }\end{array}$ \\
\hline $\begin{array}{l}\text { Modification of flood intervals: Reduction in } \\
\text { occurrence of minor floods and no change in } \\
\text { large events }\end{array}$ & $\begin{array}{l}\text { Channel narrowing through encroachment of } \\
\text { vegetation increased risk in upstream of } \\
\text { flooding and floodplain stripping during large } \\
\text { ( }>1: 10 \text { ARI) flood events }\end{array}$ \\
\hline $\begin{array}{l}\text { Change in relationship of flow and sediment } \\
\text { transport }\end{array}$ & $\begin{array}{l}\text { Decoupling of tributary and mainstream flows } \\
\text { erosion and/or deposition due to tributary } \\
\text { rejuvenation }\end{array}$ \\
\hline \multicolumn{2}{|l|}{ Loss of river connectivity } \\
\hline \multirow[t]{2}{*}{$\begin{array}{l}\text { Disconnect between flow and sediment } \\
\text { delivery }\end{array}$} & $\begin{array}{l}\text { Sediment avallability not timed with periods of } \\
\text { recession leading to decreased deposition }\end{array}$ \\
\hline & Loss of sediment 'pulse' \\
\hline
\end{tabular}

Table 3. Monthly average discharge in March and April 2016 and average increased discharge compared to the average of 1960-2009 and 2010-2015

\begin{tabular}{lcrrrrr}
\hline Station & \multicolumn{2}{c}{ Discharge for 2016 $\left(\mathbf{m}^{\mathbf{3} / \mathrm{s})}\right.$} & \multicolumn{2}{l}{$\begin{array}{l}\text { Increased discharge } \\
\text { compared to 1960-2009 }\end{array}$} & \multicolumn{2}{l}{$\begin{array}{l}\text { Increased discharge } \\
\text { compared to 2010-2015 }\end{array}$} \\
\hline & March & April & March & April & March & April \\
\hline Jinghong & 1,830 & 1,660 & 1,280 & 985 & 704 & 442 \\
Chiang Saen & 1,860 & 1,720 & 1,020 & 806 & 427 & 231 \\
Luang Prabang & 1,930 & 1,900 & 871 & 789 & 394 & 307 \\
Nong Khai & 1,960 & 2,030 & 782 & 789 & 394 & 307 \\
Nakhon Phanom & 2,650 & 3,080 & 1,070 & 1,510 & 234 & 588 \\
Mukdahan & 3,140 & 3,620 & 1,520 & 2,000 & 259 & 610 \\
Pakse & 2,990 & 3,710 & 1,120 & 1,860 & 113 & 632 \\
Stung Treng & 2,960 & 3,710 & 774 & 1,570 & -80 & 344 \\
\hline
\end{tabular}

Note:

${ }^{2}$ Cover only parts of the Basin

Source: MRC (2016)

\subsubsection{Boxes}

Boxes generally contain information that supports points given in the main text. They are inserted like figures or tables and are treated in the same way. For general rules, see the section on Figures, tables, and boxes above. 
The caption, footnotes and source are placed inside the box as follows:

CAPTION: Bold and centred at the top.

FOOTNOTE: A footnote should be placed below the text but before the source.

SOURCE: The source should be placed below the footnotes. Italicize the word 'Source'.

\section{Box 6.3. Dam development and risks associated with fisheries}

Multiple studies have flagged the risks inherent to dam development on the sustainability of fisheries resources, including:

- barrier effects on upstream and downstream fish migrations;

- mortality at hydropower structures;

- impoundment impacts;

- downstream impacts on water and fish resources;

- transboundary impacts (impact on floodplains, on the coastal zone).

Source: MRC (2019)

\subsection{Footnotes and endnotes}

Footnotes and endnotes are numbered consecutively throughout the main text. The numbering restarts at 1 for each appendix and/or annexe. In voluminous publications, this can also be applied to parts or chapters. For footnotes in figures, tables, and boxes, see Figures, tables, and boxes.

Within the body of a text, footnote numbers are inserted in superscript, outside punctuation. Footnotes appear at the foot of a page, regardless of where the text ends on the page. Endnotes appear at the end of a chapter or section or at the very end of a publication.

Footnotes contained within quotations are omitted unless the meaning or purpose of the quotation would be obscured without the footnote. If the footnote must be retained, keep the original footnote number and place the footnote directly below the quotation. The final quotation marks should follow the footnote. 


\section{6 | THE MRC WRITING, PUBLICATION \& STYLE GUIDE}

Abbreviations and acronyms used in footnotes and other references should follow the general rules given in Abbreviations and acronyms.

\subsection{Formatting and layout}

\subsubsection{Bold}

Bold is used for emphasis, NOT italics or underline or CAPITAL letters. The use of bold for this purpose should be confined to single words or phrases, not whole paragraphs.

In manuals, guides, and technical publications, bold is used for chapter headings, first- and second-level headings, and bold and italics are used for third-level headings, as shown under Headings and subheadings.

\subsubsection{Italics}

Use italics for the following:

- Foreign words that do not appear in the latest edition of the

\section{Oxford Advanced Learner's Dictionary}

- Latin names of animal and plant species

- Names of cyclones, hurricanes, tropical storms and typhoons

- Titles of books, publications, databases, periodicals, newspapers, titles of papers and articles, films, plays and radio and television programmes

- Titles of laws and decreases in a foreign language

- Variables in mathematical expressions (but not operable)

\section{Do not use italics for the following:}

- Emphasis

- Non-English names of organizations, institutions, corporations, and programmes

- El Niño and La Niña

\subsubsection{Headings and subheadings}

Headings and subheadings identify the content within sections of a paper.

Headings and subheadings that are well-formatted and worded aid both visual and nonvisual readers of all abilities. 


\section{LEVELS OF HEADINGS}

In manuals, guides and other technical publications, there are five levels of headings. Level 1 is the highest or primary level, level 2 is a subheading of level 1 , level 3 is a subheading of level 2, and so on through to levels 4 and 5 .

The number of headings to use in a manuscript depends on the length and complexity of the work.

If only one level of heading is needed, use level 1. If two levels are needed, use levels 1 and 2 . If three levels are needed, use levels 1,2 , and 3 (and so on).

Use only the number of headings necessary to differentiate distinct sections in your paper; short papers or manuscripts may not require any headings.

Furthermore, avoid these common errors related to headings:

- having only one subsection heading within a section;

- labelling headings with numbers or letters;

- using double-space headings;

- adding blank lines above or below headings, even if a heading falls at the end of a page.

\section{FORMAT OF HEADINGS}

The following table demonstrates how to format headings in five levels.

Level Format

CHAPTER HEADING, CENTRED/FLUSHED LEFT, BOLD, CAPS 20 pt.

1 FLUSH LEFT, BOLD, CAPS, TITLE CASE HEADING

Text begins as a new paragraph

Flush left, bold, lower case, title case heading

Flush left, bold italics, lower case, title case heading

$12 \mathrm{pt}$.

Text begins as a new paragraph

$12 \mathrm{pt}$.

Indented, bold, lower case, title case heading, 12 pt. 
Indented, bold italics, lower case, title case heading, ending with a period. Text begins on the same line and continues as a regular paragraph.

In numbering your headings and subheadings, be sure to avoid mixing Arabic and Roman numerals.

\subsubsection{Third-level heading (right) \\ 1.1.iv Third-level heading (wrong)}

\subsubsection{Paragraphs, subparagraphs and lists}

Paragraph numbers should be avoided unless essential for crossreferencing purposes (for example, in minutes). Do not number paragraphs in brochures, foldouts or the majority of non-technical publications. In manuals, guides and other technical publications, paragraphs and subparagraphs can be identified using numbers and letters as indicated below.

For paragraphs, use the following sequence:

1.

1.1

1.1.1

\subsubsection{1}

Try to avoid paragraph numbers longer than five figures. For example, if there is only one paragraph in a section, do not number that paragraph.

Subparagraphs and lists should be numbered as follows:

$\begin{array}{ll}\text { First degree: } & \text { (a), (b), (c), etc. } \\ \text { Second degree: } & \text { (i), (ii), (iii), etc. } \\ \text { Third degree: } & \text { a., b., c., etc. } \\ \text { Fourth degree: } & \text { i., ii., iii., etc. }\end{array}$

Example:

1. Drinking water can come from different sources depending on where we live in the world. Three common sources are: 
(a) Groundwater:

(i) is one of the primary sources for drinking water, which supplies:
a. $51 \%$ of the US population
b. $99 \%$ of the US rural population

(ii) helps grow our food and important water sources:

a. $64 \%$ is used for irrigation to grow crops

b. $16 \%$ is a source of recharge for:
i. Lakes
ii. Rivers
iii. Wetlands

c. $10 \%$ for soil moisture

d. $10 \%$ for other uses

(b) Surface water

(c) Rainwater

All the bullets should be harmonized.

Within a paragraph, use (i); (ii); and (x) and so on to list the things being described. See an example below.

- The MRC Secretariat has published three reports this month:

(i) the Basin Development Strategy; (ii) Social Impact Monitoring in the Lower Mekong River Basin; and (iii) the Annual Hydrology Report for 2018.

\subsubsection{Spacing}

Insert one space (not two) after all punctuation marks, including at the end of a sentence.

In formulae, insert a space before and after operational symbols such as $+,-, \pm, x,>,<, \geq, \leq$, = and $\approx$, except in sub(super)scripts or when they indicate sign or magnitude.

For example: $+0.47^{\circ} \mathrm{C}$ above; estimated error is $\pm 6 ; \mathrm{x}+\mathrm{y}=\mathrm{z}$; $\mathrm{xa}+\mathrm{yb}=$ $z a+b$.

Signs for binary operations and binary relations are preceded and followed by spaces: $x+y=z$; $(a \times b) \times c=a x(b \times c)$. Nevertheless, signs for binary operations are not followed by a space when they are used to modify a symbol rather than combine two mathematical symbols or expressions: $-1, \times 5$. 


\section{THE MRC WRITING, PUBLICATION \& STYLE GUIDE}

\section{Use a non-breaking space:}

- Between the currency abbreviation or symbol and the amount: f 50,000; € 1,200; USD 2,400,000

- Between a unit of measurement and the preceding number: $3 \mathrm{~kg}, 30 \mathrm{~m}, 80 \mathrm{~Hz}, 220 \mathrm{~V}$

- To separate a number from a unit: 7 times, 22 years, Part III, Chapter 5, section 2, Figure 1, Table 2, Box 3, Equation 4

- In temperature measurements: $60{ }^{\circ} \mathrm{C}, 212^{\circ} \mathrm{F}$

- In dates: 27 July 2018

\section{Do not insert spaces:}

- Between initials in names: T.H. Miller

- In geographical coordinates: $90^{\circ} \mathrm{N}, 45^{\circ} \mathrm{S}, 63^{\circ} \mathrm{E}, 13^{\circ} \mathrm{W}$

- Before and after en dashes in date or number ranges: 3-7 October, 3 June-13 July, 1996-2020, 10-12 years

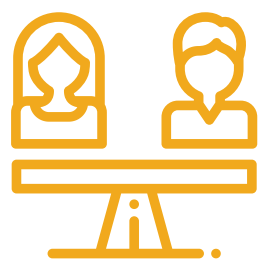

\subsection{Gender-neutral or inclusive language}

You have probably encountered documents that use masculine nouns and pronouns to refer to subject(s) whose gender is unclear or variable or to groups that contain people who are not men.

Most readers no longer interpret the word 'man' as synonymous with 'person', so clear communication requires writers to be more precise. Moreover, using gender-neutral language has become standard practice in both journalistic and academic writing.

In your manuscript, use non-sexist or gender-neutral language, which treats women and men equally.

Beware of sexist assumptions and hidden stereotypes such as:

\section{A chairman presides over the meeting.}

If the name and/or gender is unknown, do not assume that the person is male. Instead, include both male and female in the salutation, or use a gender-neutral term:

\section{Dear Madam or Sir, Dear Director, Dear colleague.}

In statements or speeches, it is now generally advisable not to use 'ladies and gentlemen' for the reasons above. 


\subsubsection{Neutral or gendered nouns}

'Man' and words ending in '-man' are the most commonly used gendered nouns in English. These words are easy to spot and replace with more neutral language, even in contexts where many readers strongly expect the gendered noun.

Ensure that words that are neutral in theory are actually used neutrally:

The Secretariat has revised its policy so that all new staff members receive health insurance for their wives.

\section{could become}

The Secretariat has revised its policy so that all new staff members receive health insurance for their spouses.

Specify gender only if necessary to the sense. A specific reference to gender can imply that women or men are exceptions in certain situations or occupations: a female director, male nurse, male cleaner.

Avoid the unnecessary use of 'man' and its compounds:

\begin{tabular}{|c|c|}
\hline Gendered noun & Replaced by gender-neutral noun \\
\hline man & person, individual, human being \\
\hline mankind & people, human beings, humanity \\
\hline fisherman & fisher \\
\hline freshman & first-year student \\
\hline man-made & machine-made, artificial, human-induced \\
\hline the common man & the average person \\
\hline chairman & chair, chairperson, coordinator, head \\
\hline mailman & mail carrier, letter carrier, postal worker \\
\hline policeman & police officer \\
\hline steward, stewardess & flight attendant \\
\hline actor, actress & actor \\
\hline congressman & legislator, congressional representative \\
\hline Sir (as in Dear Sir) & $\begin{array}{l}\text { Dear Sir or Madam, Dear Editor, } \\
\text { Dear Members of the Joint Committee, } \\
\text { To Whom It May Concern }\end{array}$ \\
\hline
\end{tabular}




\section{2 | THE MRC WRITING, PUBLICATION \& STYLE GUIDE}

\subsubsection{Titles and names}

Another example of gendered language is how the titles 'Mr,' 'Miss,' and 'Mrs' are used.

' $M r$ ' can refer to any man, regardless of whether he is single or married. Nevertheless, 'Miss' and 'Mrs' define women by whether they are married, which, until recently meant defining them by their relationships with men.

Care should be taken to use the form of address preferred by each individual. However, when that preference is not known, precedence is given to Ms over Mrs, as the former is more inclusive and can refer to any woman, regardless of marital status.

There should also be consistency in the way women and men are referred to: if one is addressed by their name, last name, courtesy title, or profession, the other should be as well.

\section{Less inclusive}

"Professor Smith (surname and title for a man) and Madeline (first name for a woman) will attend the luncheon."

\section{More inclusive}

\author{
"Professor* Smith and Professor \\ Jones will attend the luncheon \\ (surname and title for both)."
}

* Professor can be abbreviated to Prof.

\subsubsection{Personal pronouns}

Masculine pronouns cannot be used to refer to both males and females. Use 'he', 'his', 'him' or 'himself' only when referring to a male person. Where 'he' or 'his' appears only once, 'he or she' or 'his or her' can be substituted: Each author is responsible for checking his or her proofs.

However, repeating 'he or she' or 'him or her' several times in a paragraph will make the text clumsy. In some cases, the sentence may be recast in the plural or reworded to eliminate the pronoun:

Authors are responsible for checking their proofs.

Proofs are to be checked by the authors. 
Check the United Nations website (www.un.org/en/gender-inclusivelanguage/guidelines.shtml) for more gender-inclusive language.

\subsection{Numbers}

\subsubsection{Arabic numerals}

Use Arabic numerals for numbering:

- Chapters

- Annexes

- Appendices

- Attachments

- Figures, tables and boxes

- Manuals and guidelines

- Terms of reference

- Memoranda and letters

\subsubsection{Cardinal numbers}

\section{CARDINALS EXPRESSED IN FIGURES}

Numbers 10 and above are usually written in figures, except as noted in Cardinal numbers expressed in words below.

- Whole numbers of more than three digits are split as follows: $5,432,000 ; 8,9168$ (using a non-breaking space).

- Decimals are punctuated as follows: 5.3, USD 60.15, EUR 123.90, with a decimal point (not a comma).

The following are always expressed in figures:

- Percentages: Provinces with less than $25 \%$ of irrigable area were considered insufficient water availability to mitigate drought risk.

- Decimal numbers and fractions: The dam site is only $2 \mathrm{~km}$ from the border.

Note: Insert a zero before the decimal point in decimal fractions expressing a number less than 1 (for example, $0.5 \mathrm{~g}$ ). All decimal numbers in a table or series should have the same number of decimal places. 


\section{4 | THE MRC WRITING, PUBLICATION \& STYLE GUIDE}

Do not use decimal points with whole numbers or when figures are preceded by 'around' or 'approximately'.

- Ratios: The success-failure ratio of e-government in developing countries was 1 to 6 .

- Map scales: A new map on the scale of 1:250,000 was pub lished in 2010.

- Weights, units and measures: A Mekong giant catfish measuring $2.7 \mathrm{~m}$ and weighing $210 \mathrm{~kg}$ was found dead around $10 \mathrm{~km}$ from Pakse.

- Ages: Average life expectancy in Cambodia was 70 years in 2016. (exception: under-five mortality)

- Temperatures: $15^{\circ} \mathrm{C}, 92^{\circ} \mathrm{F}$

- Sums of money: USD 764,000, EUR 123.50

\section{CARDINALS EXPRESSED IN WORDS}

Numbers under 10 are generally expressed in words, except in ranges or when used with units:

five, not 5, but a 3-4-day workshop or $9 \mathrm{~km}$

a two-day workshop

Numbers are always expressed in words:

- At the beginning of a sentence: Fifteen tropical storms have hit the region this year.

- In simple fractions: Almost two thirds of the population was evacuated.

Note: Fractions expressed in words are not hyphenated (for example, one third of the total) unless used as adjectives (onethird share).

\section{COLLECTIVE YEARS}

A single period covering two or more full years is written as follows:

1992-2019 (or from 1992 to 2019)

biennium 2016-2017

the 2001-2010 decade 
A period of fewer than 24 months that overlaps two years is written as follows:

The 2015/2016 drought hit the Mekong countries hard.

\section{BIANNUAL, BIENNIAL AND THE LIKE}

Biannual means occurring twice a year.

Biennial means occurring every other year (every two years). However, these words are ambiguous because they mean either twice a month/week/year or occurring every other month/week/year.

Bimonthly, biweekly and biyearly

It is best to avoid them entirely and write 'twice a month/week/year' and 'every other month/week/year' (or 'every two months/weeks/ years') as appropriate.

\section{DECADES}

Decades are always expressed as follows:

The 1980s (not the eighties, the 80s or the 1980's).

\section{CHEMICAL FORMULAE}

The numbers in chemical formulae should be subscript:

$$
\mathrm{CO}_{2}, \mathrm{CH} 4, \mathrm{H}_{2} \mathrm{O}, \mathrm{O}_{2}, \mathrm{NO}_{x}
$$

\subsubsection{Dates}

The day is followed by the month and year: 27 October 2019. There is no comma between the month and the year: July 2018.

Write out the day in cardinal numbers, not in ordinal numbers: 15 November 2012, not $15^{\text {th }}$ November 2012.

If you include only the day and the month, the month comes before: November 15.

Months are usually written out in full but may be abbreviated (without punctuation) in tables if space is limited. 
Dates are not to be written as 5/08/20 or 5.08.20. However, where space is limited, for example, in tables, the 5.8.20 form can be used.

References to meetings should be written out as follows:

Expert Group Meeting on the Environment, Pakse, Lao PDR, 10-11 April 2019.

\subsubsection{Millions, billions and trillions}

In running text, numbers in the millions, billions and trillions are written as follows:

1 million, 3.4 million, 6 billion, 7.8 trillion

If there is more than one digit to the right of the decimal point, the number should normally be written out in full: 5,523,000 (not 5.523 million, or 5,523,000.00).

The term 'billion' means a thousand million $\left(10^{9}\right)$, while 'trillion' means a million million $\left(10^{12}\right)$.

\subsubsection{Numbers occurring together or in a series}

When two numbers occur together, they should be expressed in different styles, according to the nature of the elements and the context: 22 nine-month-old water monitoring stations.

When two or more numbers to which different rules apply occur in a series, the rule applying to the higher or highest number applies to all:

Representatives from 12 African, four Mekong countries, and two Latin American countries attended the meeting.

The Lower Mekong Basin had above-average typhoon activity in 2020, with a total of 12 storms, seven of which lasted for several days and four of which lasted for a few days.

\subsubsection{Ordinal numbers}

\section{ORDINAL NUMBERS EXPRESSED IN FIGURES}

Ordinal numbers are written in figures to indicate:

- Meeting or event numbers: 54th Meeting of the Joint Committee, and 4th meeting 
- Floors: 4th floor, 38th floor

\section{ORDINAL NUMBERS EXPRESSED IN WORDS}

Ordinal numbers from first to ninety-ninth are expressed in words for most purposes:

The MRC held its twenty-fifth Anniversary in 2020.

The MRC Council held its forty-first Meeting at the MRC Headquarters in 2018.

The word is written out for centuries: tenth century (not 10th century or $\mathrm{X}$ century).

\subsubsection{Ranges of numbers}

When two numbers are used to indicate a range, the two numbers should be homogeneous: Between 4,360,213 and 5,000,000 housing units were built (not between 4,360,213 and 5 million housing units).

To reduce the possibility of confusion, the numbers should be expressed in full, whether in words or figures: Damages from the floods were estimated at between USD 12 million and USD 15 million (not between US\$ 12 and US\$ 15 million).

When linking two numbers in a range, use the following forms:

- An en dash: Water level in Vientiane will increase by about 0.50-1.20 metres.

Note: Do not use 'from' with an en dash (not from 20\%-30\%).

- From... to ...: The Joint Committee will meet from 16 to 20 November 2020, and on 26 and 27 November 2020 in Bangkok.

Note: Do not use 'from/to' for a two-day range (not from 14 to 15 May).

- Between... and...: Sediment flow into the lower reaches of the Mekong River has reduced between $50 \%$ and $77 \%$ over the last 20 years.

Note: Do not use 'between' with 'to' (not between 15 to 20 stations).

If the unit of the range is represented by a symbol, the symbol is always repeated: 


\section{8 | THE MRC WRITING, PUBLICATION \& STYLE GUIDE}

In the warmest months of March and April, the average temperature ranges from $30^{\circ} \mathrm{C}$ to $38^{\circ} \mathrm{C}$.

\section{Prices averaged USD 20-USD 25 per kilogram.}

If the unit is written out or abbreviated, it is given only once, after the second number:

The speed of isolated storms is typically about 20-25 km per hour. A predicted sea-level rise between 25 and $30 \mathrm{~cm}$ by 2050 is expected to accelerate salinity intrusion in the Mekong Delta.

\subsubsection{Telephone and fax numbers}

Telephone and fax numbers should be written without parentheses or hyphens.

\section{Tel.: 021263263 , ext. 123 \\ Fax: 023425363}

When abbreviated, telephone is written as 'Tel.:' or simply 't:' and not 'Tel'.

Where it is appropriate to include both a country and a city code, leave a space between the two codes and between the codes and the telephone or fax number. In the following example, the first block of numbers (856) is the country code for Lao PDR and the second block (20) is the city code for Vientiane: Tel.: +856 (0) 2055551234.

The country code should always come with a plus symbol: + as in +855

Note: In some cases, as in the example above, the number contained within parentheses is considered part of the phone number only when dialling within the country.

\subsubsection{Time of day}

The MRC uses the 24-hour clock and the Gregorian calendar for most purposes. This is written in four figures and a colon ':' between the hour and the minute. Thus, the time of day is expressed as follows: 08:00 (not 8.00 a.m.), 16:05 (not 4.5 p.m.), noon, midnight.

Note: In meteorology, the 24-hour clock is used without punctuation or the colon between the hour and the minute: Tuesday, 19 June 2018, at 1800 UTC. 
In tables, figures, and charts where space is limited, abbreviate days and months as follows:

Sun. Mon. Tue. Wed. Thu. Fri. Sat.

Jan. Feb. Mar. Apr. May June July Aug. Sept. Oct. Nov. Dec.

However, there is an exception for May, June, and July because they are already very short.

\subsubsection{Units of measurement}

Use a non-breaking space between a number and a unit, except for percentages or the degree symbol in geographical coordinates: $10 \%$, $10^{\circ} \mathrm{S}, 10^{\circ} \mathrm{C}, 65^{\circ} \mathrm{F}$.

When used in conjunction with numbers, the abbreviated form of units should always be used after the first mention: $10 \mathrm{~m}$, not 10 metres.

For units of time, the accepted abbreviations are:

$\begin{array}{ll}\text { seconds } & \text { s (not sec., sec or secs) } \\ \text { minutes } & \text { min (not min. or mins) } \\ \text { hours } & h \text { (not hr or hrs) } \\ \text { days } & \text { d }\end{array}$

'years' should be written out in full, except in tables, where ' $y$ ' may be used to save space.

The slash may be used in units: $\mathrm{W} / \mathrm{m}^{2}\left(\right.$ not $\left.\mathrm{W} \mathrm{m}^{-2}\right), \mathrm{W} / \mathrm{m} 2 / \mathrm{s}$ (not $\mathrm{W}$ $\left.\mathrm{m}^{-2} \mathrm{~s}^{-1}\right), \mathrm{m} / \mathrm{s}\left(\right.$ not $\left.\mathrm{m} \mathrm{s}^{-1}\right), \mathrm{mm} / \mathrm{h}\left(\right.$ not $\left.\mathrm{mm} \mathrm{h}^{-1}\right)$.

\subsection{Punctuation}

\subsubsection{Apostrophe (')}

An apostrophe ('s or the plural form s') is the most commonly used method to show possession:

\section{Author's opinion \\ Members' actions}

Apostrophes are also used to indicate contractions, for example, where one or more letters have been omitted in a word or where two words have been joined together. Contractions are common in informal texts but not in formal texts. 


\section{Examples}

Don't = do not; it's = it is (as distinct from the possessive 'its'); who's = who is (as distinct from whose); you're = you are (as distinct from your).

An apostrophe is not used with an abbreviation/acronym or the name of an organization:

\section{MRC Joint Committee \\ MRC Headquarters}

\subsubsection{Colon (:)}

The colon primarily has three grammatical uses and several nongrammatical uses.

\section{INTRODUCING A LIST}

A colon is used to introduce an element or a series of elements, illustrating or amplifying what has preceded the colon:

To ensure accurate forecasting and monitoring, the MRC will need several types of data: historical, storage, operation, rainfall, and water level data.

Instead of a period/full stop, a colon may be used to introduce a series of related sentences:

The flash flood caused a landslide in the middle of the night: What should we do now? Warn the villagers?

The first word following the colon is in lower case, unless it is a proper name, in the following cases:

- When a colon is used within a sentence: You may be required to bring many things: sleeping bags, pans, utensils, and warm clothing.

- When a colon is used in a heading or subheading: The Mekong River: hydrology, climate and people.

Capitalize the first word after a colon in the following cases:

- To separate an independent clause from a quotation:

The CEO would often speak about wider data sharing when 
discussing the effective management of the Mekong River:

"We call on the six Mekong countries to increase data and information sharing on their dam and water infrastructure operations in a transparent and speedy manner with the MRC."

- When a colon introduces two or more sentences:

Three principles underpin these engagements: First, the extent of inter-State engagement through the MRC should be kept at a minimum. Second, there was so much water available in the wet season that transboundary impacts would be unlikely. Third, minimum dry season flows on the mainstream were maintained, and existing downstream use would not be compromised.

- When the introductory phrase is very brief, and the clause following the colon represents the gist of the message:

Remember: Only staff from the Personnel Office can enter the Private Meeting of the Management.

A colon is generally used after expressions such as 'as follows' and 'the following' but do not use more than once in any sentence. There should not be a space before a colon.

In general, do not use a colon after 'namely', 'for example' and similar expressions, or before a series introduced by a verb or preposition:

The Secretariat climatologist stressed the negative effects of sea level rise, namely that overall productivity in the Mekong Delta would decline.

There is, for example, the simple question of whether we can be certain that climate change really has changed how we live.

The revised HR Manual deals with (i) personnel benefits, (ii) education grants, (iii) ...

An application for work with the Secretariat should include a letter of interest, a CV, and an MRC Personal History Form.

\section{TIME}

A colon is used to separate hours from minutes, with no space before or after the colon: 20:15 
62 | THE MRC WRITING, PUBLICATION \& STYLE GUIDE

RATIO

It is also used to express a ratio of two numbers, with no space before or after the colon: 2:6

CORRESPONDENCE

A colon is frequently used in business and personal correspondence.

Dear Dr Green: (for a very formal purpose only. In general, a comma is used.)

From: Director of Planning Division

Attention: Personal Assistant to the CEO

PS: Please be on time.

\subsubsection{Comma (,)}

The comma might be the most troublesome punctuation mark. This is largely due to the many different ways it is used.

Generally, a serial comma should be used to punctuate the last word of a series where a final comma is used before 'and' or 'or' to increase clarity, for example, in an enumeration containing lengthy or complex elements:

Modern observations mostly come from weather stations, weather balloons, radars, ships and buoys, and satellites.

The new funding will support capacity-building programmes, education and literacy programmes, and health and social support programmes.

A comma should also be used after the first digit of a four-digit number. The exceptions include years, page numbers, and street addresses. See the section on Numbers for more detail.

We sold 2,300 books last year; the most expensive sold for USD 5,255 .

If you check his passport, you will see that he was born in October 1972.

However, do not use a comma after e.g. and i.e., before parentheses or preceding/following en dashes. 


\subsubsection{En dash (-)}

An en dash (-) is slightly wider than the hyphen (-) but narrower than the em dash (-). It is used for the following purposes:

- to join coordinating or contrasting pairs:

height-depth ratio

water-energy-food nexus

- to connect numbers, where it refers to up to and including (or through):

the Basin Development Strategy 2021-2030

You are invited to celebrate the Lao National Day on December 2, 16:00-18:00.

However, do not use the en dash if you introduce a span or range with words such as from or between:

Mr Hans Guttman was the last international CEO to have headed the MRC Secretariat from 2011 to 2014 (not from 2011-2014).

Use the en dash to set off an amplifying or defining element similar to commas, parentheses or colons, where space is inserted before and after the en dash:

The need for all the countries along the length of the Mekong China, Myanmar, Lao PDR, Thailand, Cambodia, and Viet Nam - to strike a balance among the benefits of development, social justice, and environmental sustainability is so paramount.

An average annual cost of the repercussions of floods in the Lower Mekong Basin is huge - ranging from USD 60 to USD 70 million.

\subsubsection{Forward slash (/)}

A forward-slash ( / ), also known as an upward slash, has several uses, most of which should be avoided in formal writing.

It can be used for the following purposes:

- To indicate periods that encompass parts of two consecutive calendar years: This audit covers only the 2005/2016 fiscal year.

- To link two alternative words: and/or. 
- Shorthand for per: A top speed of $60 \mathrm{~km} / \mathrm{h}$.

Between the names of two organizations in the titles of joint meetings, programmes, and projects:

\section{MRC/GIZ Report Launch on the Transboundary Joint Project between Cambodia and Thailand}

In the case of official correspondence, to indicate that more information is available on the next page(s) or that readers are directed to the next page(s). In this case, the slash is preceded by an ellipsis and followed by a period, without any space:

.../.

\subsubsection{Hyphen (-)}

For most writers, the hyphen's primary function is the formation of certain compound terms. While there are no strict rules for the use of hyphens, you should observe the following usages:

Use as dictated by the grammatical function that some words have in a sentence, for example, compound adjectives:

in depth (adv.): This subject needs to be studied in depth

in-depth (adj.): An in-depth study of this subject

land use (noun): A report on land use in Thailand

land-use (adj.): A report on land-use policies in Thailand

When two or more compound modifiers have a common base, this base is sometimes omitted except the last modifier, but the hyphens are retained: short-, medium- and long-range climate prediction.

Compound adjectives that should be hyphenated are made up of a noun + an adjective, a noun + a participle, or an adjective $+a$ participle:

\begin{tabular}{|c|c|c|}
\hline noun + adjective & noun + participle & adjective + participle \\
\hline accident-prone & computer-aided & good-looking \\
\hline sugar-free & power-driven & quick-thinking \\
\hline carbon-neutral & user-generated & bad-tempered \\
\hline basin-wide & custom-built & fair-haired \\
\hline camera-ready & muddle-headed & open-mouthed \\
\hline
\end{tabular}


With compound adjectives formed from the adverb well and a participle, or from a phrase, use a hyphen when the compound comes before the noun: well-known tool; an up-to-date account.

\section{Do not hyphenate:}

- compounds formed by an adverb ending in-ly and a participle: environmentally friendly policy to address plastic waste.

\section{Do not:}

- $\quad$ use a hyphen to indicate a negative number. Instead, use a minus sign: $-23^{\circ} \mathrm{C}$;

- use a hyphen in a number range; instead, use an en dash: 326-389;

- use MS Word's automatic hyphenation function.

\section{PREFIXES}

A hyphen is typically used after a prefix in order to prevent a word from being mistaken for another (re-treat/retreat, re-cover/recover); to avoid doubling a vowel or a consonant (re-elect, re-employ, parttime), or to link the prefix to a word beginning with a capital letter (post-Prior Consultation, pre-Columbian).

\subsubsection{Parentheses ( )}

Parentheses (always used in pairs) allow writers to provide additional information:

The Mekong River Commission (a river basin organization) was established in 1995.

However, use parentheses sparingly.

- Never use a comma before parentheses:

As noted in the glossary (see the enclosed file), a user is ...

\section{CAPITALIZATION}

- When a parenthetical sentence stands on its own, use upper case and full punctuation:

The idea that theoretical physics can be taught without reference to complex mathematics is patently absurd. (But don't 
tell that to the publishers of such mathematics-free books-or the people who buy them.)

- When parenthetical content occurs at the end of a more significant sentence, use lower case and punctuate the sentence outside the closing parenthesis.

After three weeks on set, the cast was fed up with his direction (or, rather, lack of direction).

- When a complete sentence occurs in parentheses in the middle of a larger sentence, neither capitalize nor end with a period though a question mark or exclamation point is acceptable.

We verified his degree (none of us thought he was lying about that) but not his billion-dollar verdict against us (how gullible did he think we were?).

\subsubsection{Quotation marks (" ")}

Use double quotation marks around a direct quotation. Use smart (or "curly") quotes. Never use French-style quotation marks $<<>>$. See Quotations for details.

\subsubsection{Semicolon (;)}

A semicolon is generally used at the end of a subparagraph/list item. For example, if there is a continuation of an introductory sentence, the lowercase begins, and the semicolon ends. However, in the case of full sentences, use periods instead of semicolons.

The Governance Officer sits under the Administration Division and is responsible for:

(a) preparing and providing technical support to governance meetings;

(b) serving as the primary focal person with the MRC Member Countries on governance meetings;

(c) ensuring that meeting records are timely shared with the Member Countries.

Consider these must-have qualities of a manager that can supply a roadmap to professional excellence:

(a) They build a work culture of mutual trust;

(b) They focus on employee strengths;

(c) They do not micromanage;

(d) They recognize and reward good work;

(e) They are a role model; 
(f) They handle pressure well.

Do not insert 'and' or 'or' after the semicolon of the penultimate entry.

A semicolon is often used between two independent clauses when coordinating conjunction (for, and, nor, but, or, yet, so) is omitted. Technically, the semicolon could be replaced with a period since each independent clause is a complete sentence. The semicolon, however, emphasizes the connection between the two clauses.

The upperclassmen are permitted off-campus lunch; the underclassmen must remain on campus.

\subsubsection{Square brackets [ ]}

Brackets allow the insertion of editorial material inside quotations.

- Use brackets for clarification if the original material includes a noun or pronoun that is unclear:

In his memoirs, the author reveals, "The year we moved into the house [1985] was a difficult one for us, both emotionally and financially."

- Use brackets to silently change the first letter of quoted material from upper case to lower case or vice versa:

"[T] his study has been widely cited, notwithstanding its dubious methodology."

Under the terms of his employment contract, his

"[p]erformance-based stock options shall not vest until 31 December 2025."

- When using italics to emphasize a portion of the quotation, use brackets to indicate the change:

She said she would consider "a very short extension of the deadline, but only under the most extraordinary circumstances [emphasis added]."

Use square brackets when inserting a word that is not in the original quotation (see Quotations).

Square brackets are used in reference lists to enclose English translations of non-English language references (see References). 


\section{8 | THE MRC WRITING, PUBLICATION \& STYLE GUIDE}

\subsection{Quotations}

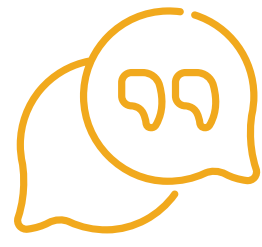

The original quotation should never be changed unless it contains obvious typos. Instead, use double quotation marks (" ") around a direct quotation.

Use single quotation marks (' ') for quotations within quotations:

On his first day at the office, the CEO said, "I am fully committed to applying the MRC motto of 'Meeting the Needs, Keeping the Balance', to social justice, poverty eradication and sustainable development."

Single quotation marks are also used for names of terms or names of projects.

The Secretariat has just launched a new programme called 'Healthy River' to promote a cleaner and greener Mekong River.

To omit material from a quotation, use an ellipsis [...] - a series of three periods/full stops - and put square brackets around it, without any space. Ellipses are preceded and followed by one space:

One study argues that "participatory governance is designed to prevent resource conflicts [...] thus creating a regional public good of equitable resource sharing while maintaining economic development" (Hensengerth, 2009, p. 327).

Quoted material running up to three lines (or 40 words) in a text should be enclosed in quotation marks within the relevant paragraph, just like an example above.

Quotations of more than three lines (or more than 40 words) should be rendered as a block quotation that is set apart from the text, indented both right and left and set in a font size two points smaller than the text, without quotation marks:

A group of researchers who studied the relationship between sand mining and riverbank stability in the Lower Mekong River state that:

There are also uncertainties regarding how much sand is being extracted from the LMR [Lower Mekong River Basin]. One study has suggested that approximately 34 million cubic metres [...] of aggregate is being extracted annually, of which $90 \%$ is sand (with the remaining $10 \%$ being coarser; that is, gravel), with more than $80 \%$ of this sediment being mined from the alluvial reaches of the 
LMR in Cambodia and Vietnam. This estimate was derived from questionnaire data collected at mining sites in four countries in the Mekong River basin [...] during low-flow conditions in 2011 and 2012. However, in the subsequent seven years since this study, demand for sand has increased considerably; hence, the commonly reported value of sediment extraction based on the 2011-2012 data is likely to be lower now than current extraction rates. (Hackney, et al., 2018)

The source of a quotation should always be acknowledged. See for detailed information.

Use square brackets ([ ]) to indicate that a word or part of a word (for example, a verb tense or a change from capital to lower case or vice versa) in a quotation has been changed or added, normally in order to incorporate a quotation into a sentence or to fit the non-quoted surrounding text:

\section{Original quotation:}

"The normal functioning of an ecosystem provides humans with an abundance of services that we depend upon or that can significantly improve our quality of life."

\section{Modified quotation:}

It is widely accepted that "[t]he normal functioning of an ecosystem provides humans with an abundance of services that we depend upon or that can significantly improve our quality of life." 


\section{PART 5: REFERENCES}

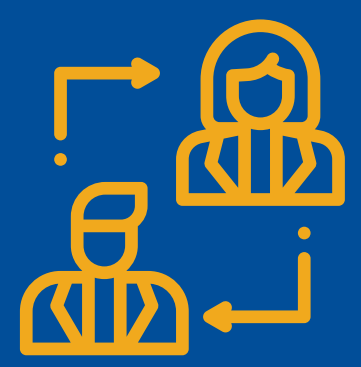

"It is the authors"

responsibility to ensure

that all references and bibliographical items are accurate, complete and correct." 


\section{PART 5: REFERENCES}

The MRC follows the APA Style for citation and referencing. It is the authors' responsibility to ensure that all references and bibliographical items are accurate, complete and correct. Editors ensure that references follow the APA Style but do not check their accuracy.

All references cited in the text must be given in the references section under the heading 'References', which should contain only those mentioned in the text.

If required, a 'Bibliography' may contain references relevant to the subject matter and recommended for further reading but not mentioned in the text.

The references and/or bibliography usually are placed at the end of a publication, after the glossary (if any) and before the annexe section.

Personal communications should not be referred to in either the references or the bibliography chapters.

All entries should follow the style and format given in the References and bibliography section examples below.

\subsection{Citing references within the text}

Include an in-text citation when you refer to, summarize, paraphrase, or quote from another source. For every in-text citation in your manuscript, there must be a corresponding entry in your reference list.

Use the author's last name and the year of publication, for example: (Green, 2005). For direct quotations, include the page number, for example: (Green, 2005, p. 14).

- Example paragraph with an in-text citation:

Knowledge is widely considered a key ingredient for the effective and sustainable governance of natural resources and ecosystems 


\section{2 | THE MRC WRITING, PUBLICATION \& STYLE GUIDE}

(Blackmore, 2007; Cash et al., 2003; van der Molen, 2018). Knowledge, in this context, includes awareness of the current state of the natural resource system and scientific understandings of the geophysical, environmental, and social processes that determine how that natural system functions and responds to stresses (Burton \& Molden, 2005; Timmerman \& Langaas, 2005).

In-text citations should immediately follow the title, word, or phrase to which they are directly relevant, rather than appearing at the end of long clauses or sentences. In addition, in-text citations should always precede punctuation marks. Below are examples of using in-text citations:

- Author's name in parentheses:

One study found that the most important element in comprehending non-native speech is familiarity with the topic (Gass \& Varonis, 1984).

Note: Use an ampersand ( $\&$ ) - not the word 'and' - in parenthetical in-text citations to separate the last and second to last author of a cited work.

- Author's name part of narrative:

Gass and Varonis (1984) found that the most important element in comprehending non-native speech is familiarity with the topic.

- Group as author:

First citation: (Mekong River Commission [MRC], 2015)

Subsequent citation: (MRC, 2015)

- Multiple works: (separate each work with semi-colons)

Research shows that listening to a particular accent improves comprehension of accented speech in general (Gass \& Varonis, 1984; Krech Thomas, 2004).

- Direct quote: (include page number)

One study found that "the listener's familiarity with the topic of discourse greatly facilitates the interpretation of the entire message" (Gass \& Varonis, 1984, p. 85).

Gass and Varonis (1984) found that "the listener's familiarity with the topic of discourse greatly facilitates the interpretation of the entire message" (p. 85). 
- When the author's name is mentioned directly in the text, only the year is given in parentheses:

According to Jones (1998), authors often have difficulty using APA style, especially when it is their first time.

The MRC's role in water diplomacy platform and regional knowledge hub was first evaluated by Lee (2010) and then by Edwards and Rose (2012), Foreman and Thomas (2018), and Baddour et al. (2019).

\subsection{Formatting and layout of references and bibliography entries}

The Reference/Bibliography section is a separate page at the end of your manuscript where all sources you cited in the main text are listed.

The references are sorted alphabetically, single-spaced, and formatted using a hanging indent of 1.27 centimetres or one tab. Use 'References' as the section heading and align it left.

A standard source reference begins with the author's surname, followed by a comma, then the initial(s) of his or her first name.

If there are multiple authors, place a comma between each author's name and an ampersand (' $\boldsymbol{\&}$ ') before the last author's name. If there are more than eight authors, list the first six followed by an ellipsis "..." (without quotation marks or any brackets) followed by the last author.

There should always be a period after the author's/authors' name(s).

But when using multiple authors' names as part of your narrative, rather than in parentheses, always spell out the word and. For multiple authors' names within a parenthetic citation, use $\boldsymbol{\&}$.

For Internet references, authors should verify the URL for each source immediately before submitting their manuscripts for editing.

Editors should test the URL provided for a source to ensure that it is correct. If it is not, editors should ask the author or consulting official for a new URL. 


\section{4 | THE MRC WRITING, PUBLICATION \& STYLE GUIDE}

Each reference must be structured according to the rules for that source type. These rules vary between books, journal articles, internet articles and others.

\subsection{References and bibliography examples}

This section provides authors with examples of how to arrange and cite references, with detailed explanations, where relevant, under each example type.

\subsubsection{Textual works}

\section{PERIODICALS}

Journals

\begin{tabular}{|c|c|}
\hline Type & Examples \\
\hline & $\begin{array}{l}\text { Grady, J. S., Her, M., Moreno, G., Perez, C., \& Yelinek, J. (2019). } \\
\text { Emotions in storybooks: A comparison of storybooks that rep- } \\
\text { resent ethnic and racial groups in the United States. Psychology } \\
\text { of Popular Media Culture, 8(3), 207-217. } \\
\text { https://doi.org/10.1037/ppm0000185 } \\
\text { - Parenthetical citation: (Grady et al., 2019) } \\
\text { - Narrative citation: Grady et al. (2019) }\end{array}$ \\
\hline \multicolumn{2}{|c|}{$\begin{array}{l}\text { Note: } \\
\text { - If a journal article has a DOI, include it in the reference. } \\
\text { - Always include the issue number for a journal article. } \\
\text { - If the journal article does not have a DOI and is from an academic research } \\
\text { database, end the reference after the page range. The reference, in this case, is } \\
\text { the same as for a print journal article. } \\
\text { - If the journal article does not have a DOI but does have a URL that will resolve } \\
\text { for readers (for example, it is from an online journal that is not part of a } \\
\text { database), include the URL of the article at the end of the reference. }\end{array}$} \\
\hline $\begin{array}{l}\text { Journal } \\
\text { article, with } \\
\text { missing } \\
\text { information }\end{array}$ & $\begin{array}{l}\text { Missing volume number } \\
\text { Stegmeir, M. (2016). Climate change: New discipline practices } \\
\text { promote college access. The Journal of College Admission, } \\
\text { (231), 44-47. https://bit.ly/3mN14pT } \\
\text { Missing issue number } \\
\text { Sanchiz, M., Chevalier, A., \& Amadieu, F. (2017). How do older } \\
\text { and young adults start searching for information? Impact } \\
\text { of age, domain knowledge and problem complexity on the } \\
\text { different steps of information searching. Computers in Human } \\
\text { Behavior, 72, 67-78. } \\
\text { https://doi.org/10.1016/j.chb.2017.02.038 }\end{array}$ \\
\hline
\end{tabular}




\begin{tabular}{|c|c|}
\hline $\begin{array}{l}\text { Journal } \\
\text { article, with } \\
\text { missing } \\
\text { information }\end{array}$ & $\begin{array}{l}\text { Missing page or article number } \\
\text { Butler, J. (2017). Where access meets multimodality: The case of } \\
\text { ASL music videos. Kairos: A Journal of Rhetoric, Technology, and } \\
\text { Pedagogy, 21(1). } \\
\text { http://technorhetoric.net/21.1/topoi/butler/index.html } \\
\text { - Parenthetical citations: (Butler, 2017; Sanchiz et al., 2017; } \\
\text { Stegmeir, 2016) } \\
\text { - Narrative citations: Butler (2017), Sanchiz et al. (2017), and } \\
\text { Stegmeir (2016) }\end{array}$ \\
\hline \multicolumn{2}{|l|}{ Note: } \\
\hline \multicolumn{2}{|c|}{$\begin{array}{l}\text { If the journal does not use volume, issue, and/or article or page numbers, omit } \\
\text { the missing element(s) from the reference. } \\
\text { - If the volume, issue, and/or article or page numbers have simply not yet been } \\
\text { assigned, use the format for an advance online publication or an in-press article. }\end{array}$} \\
\hline
\end{tabular}

\section{Newspapers}

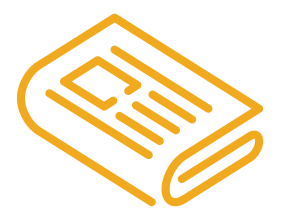

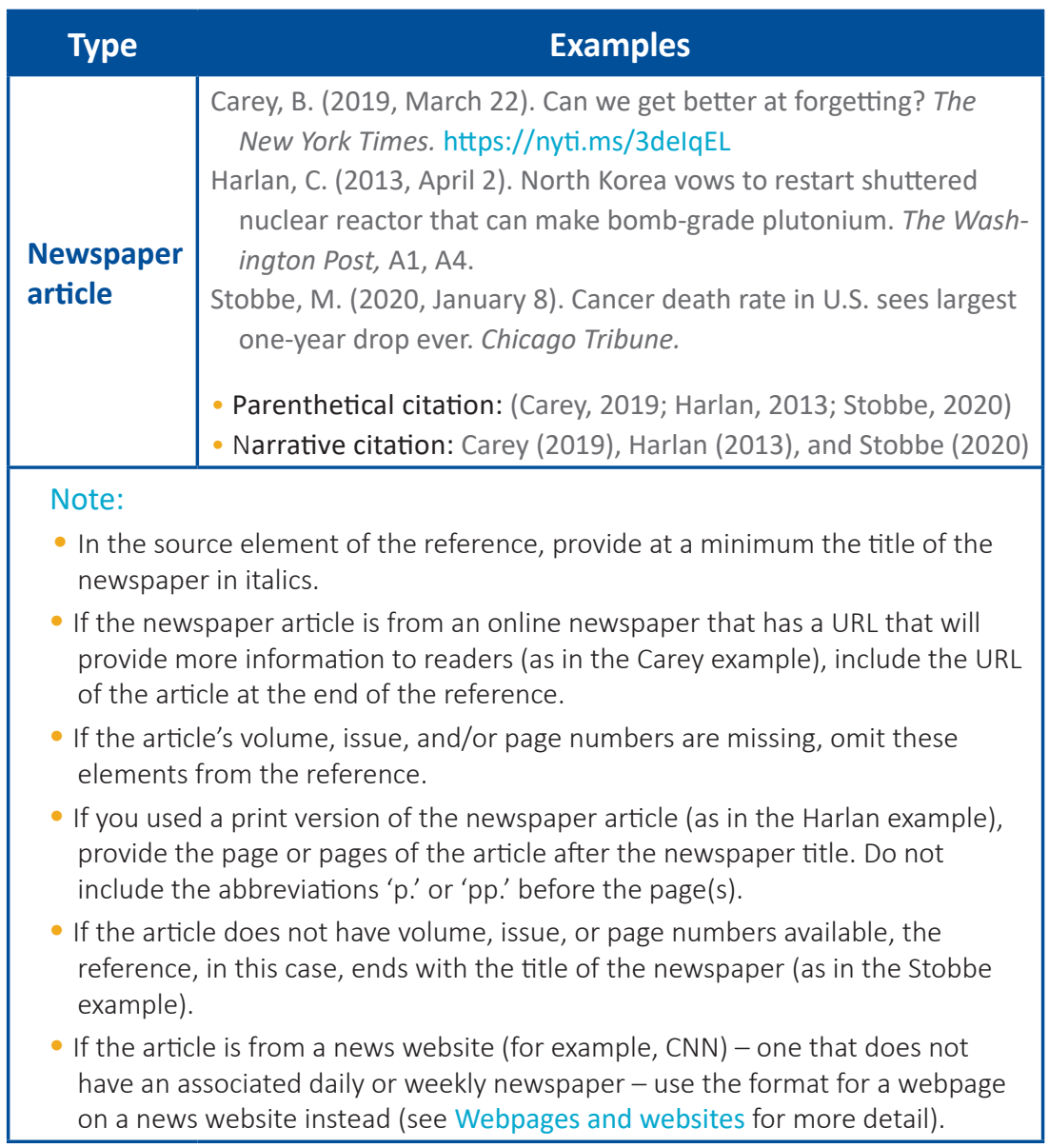




\section{6 | THE MRC WRITING, PUBLICATION \& STYLE GUIDE}

\section{BOOKS AND REFERENCE WORKS}

\section{Book references}

\begin{tabular}{|c|c|}
\hline Type & Examples \\
\hline $\begin{array}{l}\text { Whole } \\
\text { authored } \\
\text { book }\end{array}$ & $\begin{array}{l}\text { Jackson, L. M. (2019). The psychology of prejudice: From } \\
\text { attitudes to social action (2nd ed.). Washington, DC: American } \\
\text { Psychological Association. } \\
\text { https://doi.org/10.1037/0000168-000 } \\
\text { Sapolsky, R. M. (2017). Behave: The biology of humans at our best } \\
\text { and worst. New York, NY: Penguin Books. } \\
\text { - Parenthetical citation: (Jackson, 2019; Sapolsky, 2017) } \\
\text { - Narrative citation: Jackson (2019) and Sapolsky (2017) }\end{array}$ \\
\hline \multicolumn{2}{|c|}{$\begin{array}{l}\text { Note: } \\
\text { - Provide the author, year of publication, title, and publisher of the book. } \\
\text { - Include any edition information in parentheses after the title, without italics. } \\
\text { - If the book includes a DOI, include it in the reference after the publisher's name } \\
\text { - Include the publisher's location if known. } \\
\text { - If the book does not have a DOI and is an eBook from an academic research } \\
\text { database, end the book reference after the publisher's name. } \\
\text { - Do not include database information in the reference. The reference, in this } \\
\text { case, is the same as for a print book. }\end{array}$} \\
\hline & $\begin{array}{l}\text { Kesharwani, P. (Ed.). (2020). Nanotechnology based approaches } \\
\text { for tuberculosis treatment. Academic Press. } \\
\text { Torino, G. C., Rivera, D. P., Capodilupo, C. M., Nadal, K. L., \& Sue, } \\
\text { D. W. (Eds.). (2019). Microaggression theory: Influence and } \\
\text { implications. New York, NY: John Wiley \& Sons. } \\
\text { https://doi.org/10.1002/9781119466642 } \\
\text { - Parenthetical citations: (Kesharwani, 2020; Torino et al., 2019) } \\
\text { - Narrative citations: Kesharwani (2020) and Torino et al. (2019) }\end{array}$ \\
\hline \multicolumn{2}{|c|}{$\begin{array}{l}\text { Note: } \\
\text { - Use the abbreviation '(Ed.)' for one editor and the abbreviation '(Eds.)' for } \\
\text { multiple editors after the editor names, followed by a period. In the case of } \\
\text { multiple editors, include the role once, after all the names. } \\
\text { - Include any edition information in parentheses after the title, without italics. } \\
\text { - If the book includes a DOI, include it in the reference after the publisher's name. } \\
\text { - Include the publisher's location if known. } \\
\text { - If the book does not have a DOI and is an eBook from an academic research } \\
\text { database, end the book reference after the publisher's name. Do not include } \\
\text { database information in the reference. The reference, in this case, is the same } \\
\text { as for a print book. }\end{array}$} \\
\hline
\end{tabular}




Type
\begin{tabular}{|l|l|}
\hline & $\begin{array}{l}\text { Examples } \\
\text { Republished } \\
\text { actions: The case of Little Albert (D. Webb, Ed.). CreateSpace } \\
\text { book, with } \\
\text { editor }\end{array}$ \\
Independent Publishing Platform. \\
http://a.co/O6Se6Na (Original work published in 1920)
\end{tabular}
$\begin{aligned} & \text { Note: } \\
& \text { - Parenthetical citations: (Watson \& Rayner, 1920/2013) }\end{aligned}$
$\begin{aligned} & \text { - The book by Watson and Rayner was originally published in 1920. It was edited } \\
& \text { by Webb and republished in 2013. }\end{aligned}$
- Sometimes, an authored book also credits an editor on the cover. In this case,
including the editor in parentheses without italics after the book title.
- Provide the year of the republication in the main date element of the reference.
In addition, provide the year of original publication at the end of the reference
in parentheses after the words 'Original work published.'
- Both publication years appear in the in-text citation, separated with a slash, with
the earlier year first.

\section{Edited book chapters and entries}

\begin{tabular}{|c|c|}
\hline Type & Exe \\
\hline $\begin{array}{l}\text { Chapter, in } \\
\text { an edited } \\
\text { book }\end{array}$ & $\begin{array}{l}\text { Aron, L., Botella, M., \& Lubart, T. (2019). Culinary arts: Talent and } \\
\text { their development. In R. F. Subotnik, P. Olszewski-Kubilius, \& F. } \\
\text { C. Worrell (Eds.), The psychology of high performance: Develop- } \\
\text { ing human potential into domain-specific talent (pp. 345-359). } \\
\text { Washington, DC: American Psychological Association. https:// } \\
\text { doi.org/10.1037/0000120-016 } \\
\text { Dillard, J. P. (2020). Currents in the study of persuasion. In M. B. } \\
\text { Oliver, A. A. Raney, \& J. Bryant (Eds.), Media effects: Advances } \\
\text { in theory and research (4th ed., pp. 115-129). New York, NY: } \\
\text { Routledge. } \\
\text { - Parenthetical citation: (Aron et al., 2019; Dillard, 2020) } \\
\text { - Narrative citation: Aron et al. (2019) and Dillard (2020) }\end{array}$ \\
\hline \multicolumn{2}{|l|}{ Note } \\
\hline \multicolumn{2}{|c|}{$\begin{array}{l}\text { - If the edited book chapter includes a DOI, include it in the reference after the } \\
\text { publisher's name. } \\
\text { - Include the publisher's location if known. } \\
\text { - If the edited book chapter does not have a DOI and comes from an academic } \\
\text { research database, end the edited book chapter reference after the publisher's } \\
\text { name. Do not include database information in the reference. The reference, in } \\
\text { this case, is the same as for a print edited book chapter. }\end{array}$} \\
\hline \multicolumn{2}{|c|}{$\begin{array}{l}\text { - Include any edition information in the same parentheses as the page range of } \\
\text { the chapter, separated with a comma. }\end{array}$} \\
\hline
\end{tabular}




\section{THE MRC WRITING, PUBLICATION \& STYLE GUIDE}

\section{Dictionaries}

\begin{tabular}{|c|c|}
\hline Type & Examples \\
\hline $\begin{array}{l}\text { Entry in } \\
\text { an online } \\
\text { dictionary }\end{array}$ & $\begin{array}{l}\text { American Psychological Association. (n.d.). Just-world hypothesis. } \\
\text { In APA dictionary of psychology. Retrieved } 18 \text { January } 2020 \\
\text { from https://dictionary.apa.org/just-world-hypothesis } \\
\text { Merriam-Webster. (n.d.). Semantics. In Merriam-Webster.com } \\
\text { dictionary. Retrieved } 4 \text { January } 2020 \text { from https://www.merri- } \\
\text { am-webster.com/dictionary/semantics } \\
\text { - Parenthetical citation: (American Psychological Association, } \\
\text { n.d.; Merriam-Webster, n.d.) } \\
\text { - Narrative citation: American Psychological Association (n.d.) } \\
\text { and Merriam-Webster (n.d.) }\end{array}$ \\
\hline \multicolumn{2}{|c|}{$\begin{array}{l}\text { Because entries in the APA Dictionary of Psychology and Merriam-Webster's } \\
\text { Dictionary are updated over time and are not archived, include a retrieval date } \\
\text { in the reference. } \\
\text { - The author and publisher are the same for the dictionaries in the examples, so } \\
\text { the name appears in the author element only to avoid repetition. }\end{array}$} \\
\hline $\begin{array}{l}\text { Entry in } \\
\text { a printed } \\
\text { dictionary }\end{array}$ & $\begin{array}{l}\text { American Psychological Association. (2015). Mood induction. In } \\
\text { APA dictionary of psychology ( } 2 \text { nd ed., p. 667). } \\
\text { Merriam-Webster. (2003). Litmus test. In Merriam-Webster's } \\
\text { collegiate dictionary (11th ed., p. 727). } \\
\text { - Parenthetical citation: (American Psychological Association, } \\
\text { 2015; Merriam-Webster, 2003) } \\
\text { - Narrative citation: American Psychological Association (2015) } \\
\text { and Merriam-Webster (2003) }\end{array}$ \\
\hline \multicolumn{2}{|l|}{ Note: } \\
\hline $\begin{array}{l}\text { The auth } \\
\text { the name } \\
\text { - Provide a } \\
\text { italics aft } \\
\text { - Provide t } \\
\text { dictionar } \\
\text { the same }\end{array}$ & $\begin{array}{l}\text { nd publisher are the same for the dictionaries in the examples, so } \\
\text { pears in the author element only to avoid repetition. } \\
\text { edition information about the dictionary in parentheses without } \\
\text { he dictionary title. } \\
\text { oage number for the entry in parentheses after the title of the } \\
\text { /hen both an edition and page number are present, place them in } \\
\text { of parentheses, separated by a comma. }\end{array}$ \\
\hline
\end{tabular}

\section{Reports and grey literature}

\begin{tabular}{|c|c|}
\hline Type & Examples \\
\hline $\begin{array}{l}\text { Report by a } \\
\text { Government } \\
\text { Agency } \\
\text { reference }\end{array}$ & $\begin{array}{l}\text { National Cancer Institute. (2019). Taking time: Support for people } \\
\text { with cancer (NIH Publication No. 18-2059). Bethesda, MD: US } \\
\text { Department of Health and Human Services, National Institutes } \\
\text { of Health. https://www.cancer.gov/publications/patient-educa- } \\
\text { tion/takingtime.pdf } \\
\text { - Parenthetical citations: (National Cancer Institute, 2019) } \\
\text { - Narrative citations: National Cancer Institute (2019) }\end{array}$ \\
\hline
\end{tabular}




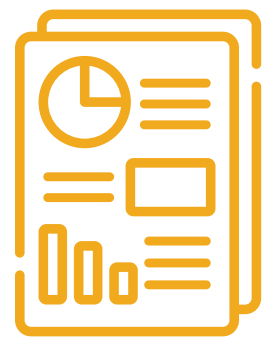

\begin{tabular}{|c|c|}
\hline Type & Examples \\
\hline \multicolumn{2}{|l|}{ Note: } \\
\hline $\begin{array}{l}\text { Report with } \\
\text { individual } \\
\text { authors } \\
\text { references }\end{array}$ & $\begin{array}{l}\text { Baral, P., Larsen, M., \& Archer, M. (2019). Does money grow on } \\
\text { trees? Restoration financing in Southeast Asia. Washington, DC: } \\
\text { Atlantic Council. https://bit.ly/34LWtOj } \\
\text { Stuster, J., Adolf, J., Byrne, V., \& Greene, M. (2018). Human } \\
\text { exploration of Mars: Preliminary lists of crew tasks (Report No. } \\
\text { NASA/CR-2018-220043). Houston, TX: National Aeronautics and } \\
\text { Space Administration. https://go.nasa.gov/3oQi2oX } \\
\text { - Parenthetical citations: (Baral et al., 2019; Stuster et al., 2018) } \\
\text { - Narrative citations: Baral et al. (2019) and Stuster et al. (2018) }\end{array}$ \\
\hline \multicolumn{2}{|c|}{$\begin{array}{l}\text { Note: } \\
\text { - If the report has a report number, include it in parentheses without italics after } \\
\text { the report title. } \\
\text { - Provide the publisher of the report and its URL in the source element of the } \\
\text { reference. } \\
\text { - Include the publisher's location if known. }\end{array}$} \\
\hline $\begin{array}{l}\text { Fact sheet } \\
\text { references }\end{array}$ & $\begin{array}{l}\text { MRC. (2020). Joint Environmental Monitoring Programme Pilot } \\
\text { Project [Fact sheet]. Vientiane. https://bit.ly/2G3ObYs } \\
\text { Agency for Toxic Substances and Disease Registry. (n.d.). Asbestos } \\
\text { in your environment: What you can do to limit exposure [Fact } \\
\text { sheet]. Washington, DC: US Department of Health \& Human } \\
\text { Services. https://bit.ly/3kPOwNV } \\
\text { - Parenthetical citations: (Agency for Toxic Substances and } \\
\text { Disease Registry, n.d.; MRC, 2020) } \\
\text { - Narrative citations: Agency for Toxic Substances and Disease } \\
\text { Registry (n.d.) and MRC (2020) }\end{array}$ \\
\hline \multicolumn{2}{|l|}{ Note: } \\
\hline \multicolumn{2}{|c|}{$\begin{array}{l}\text { - Fact sheets, brochures, pamphlets, or flyers follow the same format as report } \\
\text { references. } \\
\text { - This fact sheet has an organizational author rather than individual authors. } \\
\text { - Include the description '[Fact sheet]' in square brackets after the title of the } \\
\text { brochure. }\end{array}$} \\
\hline \multicolumn{2}{|c|}{$\begin{array}{l}\text { When the multiple layers of government agencies are credited (as in the Agency } \\
\text { for Toxic Substances and Disease Registry example), provide the most specific } \\
\text { agency in the author element of the reference. Provide the parent agency in the } \\
\text { source element of the reference as the publisher. }\end{array}$} \\
\hline \multicolumn{2}{|c|}{$\begin{array}{l}\text { When only one agency is credited as the author (as in the MRC example), } \\
\text { provide that agency as the author. Omit the agency name from the source } \\
\text { element to avoid repetition. }\end{array}$} \\
\hline & \\
\hline
\end{tabular}


THE MRC WRITING, PUBLICATION \& STYLE GUIDE

\begin{tabular}{|c|c|}
\hline Type & Examples \\
\hline $\begin{array}{l}\text { Media } \\
\text { release } \\
\text { references }\end{array}$ & $\begin{array}{l}\text { MRC. (2020, August 7). Mekong countries urged to address } \\
\text { low water flows: Mekong River Commission [Media release]. } \\
\text { Vientiane. https://bit.ly/3gFWxTq } \\
\text { - Parenthetical citations: (MRC, 2020) } \\
\text { - Narrative citations: MRC (2020) }\end{array}$ \\
\hline \multicolumn{2}{|c|}{$\begin{array}{l}\text { Note: } \\
\text { - Provide the name of the group that released the media/press release as the } \\
\text { author. } \\
\text { - Include the description '[Media release]' in square brackets after the title of the } \\
\text { media release. } \\
\text { - When the author and the publisher of the media release are the same, omit the } \\
\text { publisher to avoid repetition, as shown in the example. } \\
\text { - Include the publisher's location if known. }\end{array}$} \\
\hline $\begin{array}{l}\text { White paper, } \\
\text { with a group } \\
\text { author }\end{array}$ & $\begin{array}{l}\text { Department for Business Innovation \& Skills. (2016). Success as } \\
\text { a knowledge economy: Teaching excellent, social mobility and } \\
\text { student choice [White paper]. London: Crown. } \\
\text { https://bit.ly/2Tluyse } \\
\text { - Parenthetical citations: (Department for Business Innovation \& } \\
\text { Skills, 2016) } \\
\text { - Narrative citations: Department for Business Innovation \& Skills } \\
\text { (2016) }\end{array}$ \\
\hline \multicolumn{2}{|c|}{$\begin{array}{l}\text { Note: } \\
\text { - A white paper is a persuasive document that is written by a person or group to } \\
\text { convince readers of their position and philosophy on a topic. } \\
\text { - Include the description '[White paper]' in square brackets after the title of the } \\
\text { white paper. } \\
\text { - Include the publisher's location if known. }\end{array}$} \\
\hline $\begin{array}{l}\text { White } \\
\text { paper, with } \\
\text { individual } \\
\text { authors }\end{array}$ & $\begin{array}{l}\text { Furst, M., \& DeMillo, R. A. (2006). Creating symphonic-thinking } \\
\text { computer science graduates for an increasingly competitive } \\
\text { global environment [White paper]. Atlanta, GA: Georgia Tech } \\
\text { College of Computing. https://bit.ly/3oVEHAz } \\
\text { - Parenthetical citations:(Furst \& DeMillo, 2006) } \\
\text { - Narrative citations: Furst \& DeMillo (2006) }\end{array}$ \\
\hline
\end{tabular}

\section{Conference presentations and proceedings}

\begin{tabular}{|c|c|}
\hline Type & Examples \\
\hline $\begin{array}{l}\text { Conference } \\
\text { presentation }\end{array}$ & $\begin{array}{l}\text { Evans, A. C., Jr., Garbarino, J., Bocanegra, E., Kinscherff, R. T., \& } \\
\text { Márquez-Greene, N. (2019, August 8-11). Gun violence: An } \\
\text { event on the power of community [Conference presentation]. } \\
\text { APA } 2019 \text { Convention, Chicago, IL, United States of America. } \\
\text { https://convention.apa.org/2019-video } \\
\text { - Parenthetical citations: (Evans et al., } 2019 \\
\text { - Narrative citations: Evans et al. (2019) }\end{array}$ \\
\hline
\end{tabular}




\section{Type}

\section{Examples}

Note:

- Provide the names of the presenters in the author element of the reference.

- Provide the full dates of the conference in the date element of the reference.

- Describe the presentation in square brackets after the title. The description is flexible (for example, '[Conference session],' '[Paper presentation],' '[Poster session],' '[Keynote address]').

- Provide the name of the conference or meeting and its location in the source element of the reference.

- If a video of the conference presentation is available, include a link at the end of the reference.

\begin{tabular}{|c|c|}
\hline $\begin{array}{l}\text { Conference } \\
\text { proceedings } \\
\text { published in } \\
\text { a journal }\end{array}$ & $\begin{array}{l}\text { Duckworth, A. L., Quirk, A., Gallop, R., Hoyle, R. H., Kelly, D. R., \& } \\
\text { Matthews, M. D. (2019). Cognitive and noncognitive predictors } \\
\text { of success. Proceedings of the National Academy of Sciences, } \\
\text { USA, 116(47), 23499-23504. } \\
\text { https://doi.org/10.1073/pnas.1910510116 } \\
\text { - Parenthetical citations:(Duckworth et al., 2019) } \\
\text { - Narrative citations: Duckworth et al. (2019) }\end{array}$ \\
\hline \multicolumn{2}{|l|}{ Note: } \\
\hline $\begin{array}{l}\text { Conference } \\
\text { proceedings } \\
\text { published as } \\
\text { a whole book }\end{array}$ & $\begin{array}{l}\text { Kushilevitz, E., \& Malkin, T. (Eds.). (2016). Lecture notes in } \\
\text { computer science: Vol. 9562. Theory of cryptography. Springer. } \\
\text { https://doi.org/10.1007/978-3-662-49096-9 } \\
\text { - Parenthetical citations: (Kushilevitz \& Malkin, 2016) } \\
\text { - Narrative citations: Kushilevitz \& Malkin (2016) }\end{array}$ \\
\hline \multicolumn{2}{|c|}{$\begin{array}{l}\text { - Conference proceedings published as a whole book follow the same reference } \\
\text { format as whole edited books. }\end{array}$} \\
\hline $\begin{array}{l}\text { Conference } \\
\text { proceedings } \\
\text { published } \\
\text { as a book } \\
\text { chapter }\end{array}$ & $\begin{array}{l}\text { Bedenel, A.-L., Jourdan, L., \& Biernacki, C. (2019). Probability } \\
\text { estimation by an adapted genetic algorithm in web insurance. } \\
\text { In R. Battiti, M. Brunato, I. Kotsireas, \& P. Pardalos (Eds.), } \\
\text { Lecture notes in computer science: Vol. 11353. Learning and } \\
\text { intelligent optimization (pp. 225-240). Springer. } \\
\text { https://doi.org/10.1007/978-3-030-05348-2_21 } \\
\text { - Parenthetical citations: (Bedenel, Jourdan \& Biernacki, 2019) } \\
\text { - Narrative citations: Bedenel, Jourdan \& Biernacki (2019) }\end{array}$ \\
\hline & . \\
\hline
\end{tabular}




\section{THE MRC WRITING, PUBLICATION \& STYLE GUIDE}

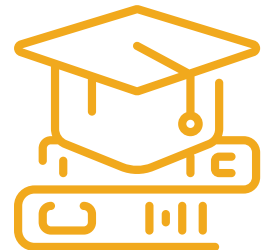

\section{Dissertations and theses}

\begin{tabular}{|c|c|}
\hline Type & es \\
\hline $\begin{array}{l}\text { Published } \\
\text { dissertation } \\
\text { or thesis } \\
\text { references }\end{array}$ & $\begin{array}{l}\text { Kabir, J. M. (2016). Factors influencing customer satisfaction at a } \\
\text { fast food hamburger chain: The relationship between customer } \\
\text { satisfaction and customer loyalty (Publication No. 10169573) } \\
\text { [Doctoral dissertation, Wilmington University]. ProQuest } \\
\text { Dissertations \& Theses Global. } \\
\text { Miranda, C. (2019). Exploring the lived experiences of foster } \\
\text { youth who obtained graduate level degrees: Self-efficacy, } \\
\text { resilience, and the impact on identity development (Publication } \\
\text { No. 27542827) [Doctoral dissertation, Pepperdine University]. } \\
\text { PQDT Open. } \\
\text { https://pqdtopen. proquest.com/doc/2309521814. } \\
\text { html?FMT=Al } \\
\text { Zambrano-Vazquez, L. (2016). The interaction of state and } \\
\text { trait worry on response monitoring in those with worry and } \\
\text { obsessive-compulsive symptoms [Doctoral dissertation, } \\
\text { University of Arizona]. UA Campus Repository. } \\
\text { https://repository.arizona.edu/handle/10150/620615 } \\
\text { - Parenthetical citations: (Kabir, 2016; Miranda, 2019; Zambrano- } \\
\text { Vazquez, 2016) } \\
\text { - Narrative citations: Kabir (2016), Miranda (2019), and } \\
\text { Zambrano-Vazquez (2016) }\end{array}$ \\
\hline \multicolumn{2}{|l|}{ Note: } \\
\hline \multicolumn{2}{|c|}{$\begin{array}{l}\text { - A dissertation or thesis is considered published when it is available from a } \\
\text { database such as ProQuest Dissertations and Theses Global or PDQT Open, an } \\
\text { institutional repository, or an archive. }\end{array}$} \\
\hline \multicolumn{2}{|c|}{$\begin{array}{l}\text { - If the database assigns publication numbers to dissertations and theses include } \\
\text { the publication number in parentheses after the title of the dissertation or } \\
\text { thesis without italics. }\end{array}$} \\
\hline \multicolumn{2}{|c|}{$\begin{array}{l}\text { - Include the description 'Doctoral dissertation' or 'Master's thesis' followed by } \\
\text { a comma and the name of the institution that awarded the degree. Place this } \\
\text { information in square brackets after the dissertation or thesis title and any } \\
\text { publication number. }\end{array}$} \\
\hline \multicolumn{2}{|c|}{$\begin{array}{l}\text { - In the source element of the reference, provide the database, repository, or } \\
\text { archive name. }\end{array}$} \\
\hline \multicolumn{2}{|c|}{$\begin{array}{l}\text { - The same format can be adapted for other published theses, including } \\
\text { undergraduate theses, by changing the wording of the bracketed description as } \\
\text { appropriate (such as 'Undergraduate honours thesis'). }\end{array}$} \\
\hline \multicolumn{2}{|c|}{$\begin{array}{l}\text { - Include a URL for the dissertation or thesis if the URL will resolve for readers (as } \\
\text { shown in the Miranda and Zambrano-Vazquez examples). }\end{array}$} \\
\hline \multicolumn{2}{|c|}{$\begin{array}{l}\text { - If the database or archive requires users to log in before they can view the } \\
\text { dissertation or thesis, meaning the URL will not work for readers, end the } \\
\text { reference with the database name (as in the Kabir example). }\end{array}$} \\
\hline
\end{tabular}




\begin{tabular}{|c|c|}
\hline Type & Examples \\
\hline $\begin{array}{l}\text { Unpublished } \\
\text { dissertation } \\
\text { or thesis } \\
\text { references }\end{array}$ & $\begin{array}{l}\text { Harris, L. (2014). Instructional leadership perceptions and } \\
\text { practices of elementary school leaders [Unpublished doctoral } \\
\text { dissertation]. University of Virginia. } \\
\text { - Parenthetical citations: (Harris, 2014) } \\
\text { - Narrative citations: Harris (2014) }\end{array}$ \\
\hline \multicolumn{2}{|l|}{ Note: } \\
\hline \multicolumn{2}{|c|}{$\begin{array}{l}\text { When a dissertation or thesis is unpublished, include the description } \\
\text { '[Unpublished doctoral dissertation]' or '[Unpublished master's thesis]' in } \\
\text { square brackets after the dissertation or thesis title. }\end{array}$} \\
\hline \multicolumn{2}{|c|}{$\begin{array}{l}\text { - In the source element of the reference, provide the institution's name that } \\
\text { awarded the degree. }\end{array}$} \\
\hline \multicolumn{2}{|c|}{$\begin{array}{l}\text { The same format can be adapted for other unpublished theses, including } \\
\text { undergraduate theses, by changing the wording of the bracketed description as } \\
\text { appropriate. }\end{array}$} \\
\hline \multicolumn{2}{|c|}{$\begin{array}{l}\text { - If you find the dissertation or thesis in a database or a repository or archive, } \\
\text { follow the published dissertation or thesis reference examples. }\end{array}$} \\
\hline
\end{tabular}

\subsubsection{Data sets}

\section{Data set references}

\begin{tabular}{|c|c|}
\hline Type & Examples \\
\hline Data set & $\begin{array}{l}\text { O'Donohue, W. (2017). Content analysis of undergraduate psy- } \\
\text { chology textbooks (ICPSR 21600; Version V1) [Data set]. ICPSR. } \\
\text { https://doi.org/10.3886/ICPSR36966.v1 } \\
\text { - Parenthetical citation: (O’Donohue, 2017) } \\
\text { - Narrative citation: O’Donohue (2017) }\end{array}$ \\
\hline \multicolumn{2}{|c|}{$\begin{array}{l}\text { Provide citations for data sets when you have either conducted secondary } \\
\text { analyses of publicly archived data or archived your data presented for the first } \\
\text { time in the current work. }\end{array}$} \\
\hline \multicolumn{2}{|c|}{$\begin{array}{l}\text { If you cite existing data or statistics, cite the publication in which the data were } \\
\text { published (such as a journal article, report, or webpage) rather than the data set } \\
\text { itself. }\end{array}$} \\
\hline \multicolumn{2}{|c|}{$\begin{array}{l}\text { The date in the reference is the year of publication for the version of the data } \\
\text { used. }\end{array}$} \\
\hline \multicolumn{2}{|c|}{$\begin{array}{l}\text { Provide the title of the data set in italics. Then provide any numerical identifier } \\
\text { and version number for the data in parentheses without italics, separated by a } \\
\text { semicolon. }\end{array}$} \\
\hline \multicolumn{2}{|c|}{$\begin{array}{l}\text { - The bracketed description is flexible (such as '[Data set],' '[Data set and code } \\
\text { book]'). }\end{array}$} \\
\hline \multicolumn{2}{|c|}{$\begin{array}{l}\text { - Provide the publisher of the data set in the source element. ICPSR is one } \\
\text { common example. }\end{array}$} \\
\hline
\end{tabular}




\section{THE MRC WRITING, PUBLICATION \& STYLE GUIDE}

Toolbox references

\begin{tabular}{|c|c|}
\hline Type & Examples \\
\hline Toolbox & $\begin{array}{l}\text { Shi, Y., Ma, X., Ma, Z., Wang, J., Yao, N., Gu, Q., Wang, C., \& Gao, } \\
\text { Z. (2018). Using a Kinect sensor to acquire biological motion: } \\
\text { Toolbox and evaluation. Behavior Research Methods, 50(2), } \\
\text { 518-529. https://doi.org/10.3758/s13428-017-0883-9 } \\
\text { - Parenthetical citation: (Shi et al., 2018) } \\
\text { - Narrative citation: Shi et al. (2018) }\end{array}$ \\
\hline \multicolumn{2}{|c|}{$\begin{array}{l}\text { Note: } \\
\text { - A toolbox is a set of statistical tools that researchers can use to analyse data, for } \\
\text { example, to analyse distributions or to perform statistical modelling. } \\
\text { - To cite a toolbox, cite the work in which the toolbox was published (typically a } \\
\text { journal article or conference presentation). } \\
\text { - Mention the name of the toolbox in the narrative if desired: } \\
\text { - The Kinect-based biological motion capture (KBC) toolbox allows researchers to } \\
\text { capture biological motion information gathered using point-light displays (Shi et } \\
\text { al., 2018). }\end{array}$} \\
\hline
\end{tabular}

\subsubsection{Audio-visual media}

\section{AUDIO-VISUAL MEDIA}

\section{Online course or $\mathrm{MOOC}$ references}

\begin{tabular}{|c|c|}
\hline Type & Examples \\
\hline $\begin{array}{l}\text { Online course } \\
\text { or massive } \\
\text { open online } \\
\text { course } \\
\text { (MOCC) }\end{array}$ & $\begin{array}{l}\text { Jackson, M. O., Leyton-Brown, K., \& Shoham, Y. (n.d.). Game } \\
\text { theory [MOOC]. Coursera. } \\
\text { https://www.coursera.org/learn/game-theory-1 } \\
\text { - Parenthetical citation: (Jackson et al., n.d.) } \\
\text { - Narrative citation: Jackson et al. (n.d.) }\end{array}$ \\
\hline \multicolumn{2}{|c|}{$\begin{array}{l}\text { Note: } \\
\text { Online courses, including MOOCs, can be cited by providing the instructors, year } \\
\text { of course creation (if known), title of the course, site that hosts the course, and } \\
\text { URL. }\end{array}$} \\
\hline $\begin{array}{l}\text { Lecture from } \\
\text { an online } \\
\text { course or } \\
\text { MOCC }\end{array}$ & $\begin{array}{l}\text { Tangen, J. (2016). Episode 2: I heard a tapping somewhat louder } \\
\text { than before [MOOC lecture]. In E. MacKenzie, J. Tangen, \& M. } \\
\text { Thompson, The science of everyday thinking. edX. } \\
\text { https://www.edx.org/course/the-science-of-everyday-thinking } \\
\text { - Parenthetical citation: (Tangen, 2016) } \\
\text { - Narrative citation: Tangen (2016) }\end{array}$ \\
\hline
\end{tabular}


Note:

- A lecture, other content from an online course, or $\mathrm{MOOC}$ is cited similarly to a podcast episode, with the instructor of the lecture listed in the author element of the reference and the names of all course faculty in the editor position within the source element.

- Provide a link that will resolve for readers. For example, because users must enrol in the course and then log in to access the lecture, the link in the reference leads to the main page for the course

\section{YouTube video references}

\begin{tabular}{|c|c|}
\hline Type & \\
\hline & $\begin{array}{l}\text { Asian Boss. (2020, June 5). World's leading vaccine expert fact-checks } \\
\text { COVID-19 vaccine conspiracy: Stay curious \#22 [Video]. YouTube. } \\
\text { https://www.youtube.com/watch?v=WQdLDMLrYIA } \\
\text { Harvard University. (2019, August 28). Soft robotic gripper for jellyfish } \\
\text { [Video]. YouTube. https://www.youtube.com/watch?v=guRoWTY- } \\
\text { fxMs } \\
\text { - Parenthetical citation: Asian Boss, 2020; Harvard University, 2019) } \\
\text { - Narrative citation: Asian Boss (2020) and Harvard University (2019) }\end{array}$ \\
\hline \multicolumn{2}{|c|}{$\begin{array}{l}\text { Note: } \\
\text { - The same format can be used for other sites that host user-generated videos, } \\
\text { such as Vimeo. } \\
\text { - Use the name of the account that uploaded the video as the author. } \\
\text { - If the account did not create the work, explain this in the text if readers } \\
\text { need to know. However, if this would require citing a source that appears } \\
\text { unauthoritative, you might also look for the author's YouTube channel, official } \\
\text { website, or other social media to see whether the same video is available } \\
\text { elsewhere. } \\
\text { - To cite the words of individuals featured in a video, name or describe the } \\
\text { individual(s) in your sentence in the text and then provide a parenthetical } \\
\text { citation for the video. For example, the Asian Boss video is an interview with } \\
\text { the director-general of the International Vaccine Institute; you should provide } \\
\text { details about who spoke and what they said in the text of the sentence and then } \\
\text { cite the video using the parenthetical citation shown. } \\
\text { - Provide the specific date on which the video was uploaded. } \\
\text { - Italicize the title of the video. } \\
\text { - Include the description '[Video]' in square brackets after the title. } \\
\text { - Provide the site name (YouTube) and URL of the video. }\end{array}$} \\
\hline & $\begin{array}{l}\text { A Publishing Training. (n.d.). Home [YouTube channel]. Retrieved } 20 \\
\text { February } 2020 \text { from https://www.youtube.com/user/PsyclNFO/ } \\
\text { alker, A. (n.d.). Playlists [YouTube channel]. YouTube. Retrieved } 8 \\
\text { October } 2019 \text { from https://www.youtube.com/user/DjWalkzz/ } \\
\text { playlists } \\
\text { Parenthetical citation: (APA Publishing Training, n.d.; Walker, n.d.) }\end{array}$ \\
\hline
\end{tabular}




\section{THE MRC WRITING, PUBLICATION \& STYLE GUIDE}

Type Examples
Note:
- YouTube channel pages begin on the 'Home' tab by default. However, if you
want to cite one of the other tabs (such as "Videos," "Playlists"), use the name
of that tab rather than 'Home' in the title element of the reference (as in the
Walker example).
- Italicize the title of the channel.
- Include the description '[YouTube channel]' in square brackets after the title.
Provide a retrieval date because the content is designed to change over time
and is not archived.

\section{TED talk references}

\begin{tabular}{|c|c|}
\hline Type & $E x$ \\
\hline $\begin{array}{l}\text { TED talk } \\
\text { from the TED } \\
\text { website }\end{array}$ & $\begin{array}{l}\text { Cuddy, A. (2012, June). Your body language may shape who you } \\
\text { are [Video]. TED Conferences. https://bit.ly/3egljci } \\
\text { - Parenthetical citations: (Cuddy, 2012) } \\
\text { - Narrative citations: Cuddy (2012) }\end{array}$ \\
\hline \multicolumn{2}{|c|}{$\begin{array}{l}\text { Note: } \\
\text { - When the TED Talk comes from TED's website, use the name of the speaker as } \\
\text { the author. } \\
\text { - Provide as specific a date as possible; only the year and month are available in } \\
\text { the example. } \\
\text { - Include the description "[Video]" in square brackets after the title of the talk. } \\
\text { - Credit TED Conferences as the publisher of the TED Talk and then provide the } \\
\text { URL }\end{array}$} \\
\hline $\begin{array}{l}\text { TED talk from } \\
\text { YouTube }\end{array}$ & $\begin{array}{l}\text { TED. (2019, November 13). The danger of Al is weirder than you } \\
\text { think / Janelle Shane [Video]. YouTube. } \\
\text { https://www.youtube.com/watch?v=OhCzXOiLnOc } \\
\text { - Parenthetical citations: (TED, 2019) } \\
\text { - Narrative citations: TED (2019) }\end{array}$ \\
\hline $\begin{array}{l}\text { Note: } \\
\text { - When the TE } \\
\text { TED) as the } \\
\text { - Provide as sI } \\
\text { - Include the } \\
\text { - Credit YouTu } \\
\text { When the sp } \\
\text { narrative if c } \\
\text { Shane e } \\
\text { asked it }\end{array}$ & $\begin{array}{l}\text { D Talk is on YouTube, list the owner of the YouTube account (here, } \\
\text { author to aid in retrieval. } \\
\text { Decific a date as possible. } \\
\text { description '[Video]' in square brackets after the title of the talk. } \\
\text { be as the publisher of the TED Talk and then provide the URL. } \\
\text { eaker is not listed as the author, integrate their name into the } \\
\text { esired: } \\
\text { xplained that the artificial intelligence technically "did what they } \\
\text { to do - they just accidentally asked it to do the wrong thing" (TED, } \\
51 \text { ). }\end{array}$ \\
\hline
\end{tabular}




\subsubsection{Online media}

SOCIAL MEDIA

Facebook

\begin{tabular}{|c|c|}
\hline Type & Examples \\
\hline $\begin{array}{l}\text { Facebook } \\
\text { post }\end{array}$ & $\begin{array}{l}\text { Mekong River Commission. (2020, October 22). Congratulations } \\
\text { MRC! Today, the MRC and China have signed an agreement, } \\
\text { which will see China begin sharing year-round hydrological } \\
\text { data. [Status update]. Facebook. https://bit.ly/2TKhcMd } \\
\text { - Parenthetical citations: (Mekong River Commission, 2020) } \\
\text { - Narrative citations: Mekong River Commission (2020) }\end{array}$ \\
\hline \multicolumn{2}{|l|}{ Note: } \\
\hline \multicolumn{2}{|c|}{ - Use the name associated with the account as the name in the reference. } \\
\hline \multicolumn{2}{|c|}{ - Provide the specific date of the post. } \\
\hline \multicolumn{2}{|c|}{$\begin{array}{l}\text { Provide the first } 20 \text { words of the post as the title. Count a URL or other link, a } \\
\text { hashtag, or an emoji as one word each, and include them in the reference if } \\
\text { they fall within the first } 20 \text { words. Do not italicize emojis. }\end{array}$} \\
\hline \multicolumn{2}{|c|}{$\begin{array}{l}\text { - If a post includes images, videos, thumbnail links to outside sources, or content } \\
\text { from another post (such as when sharing a link), indicate this in square brackets. }\end{array}$} \\
\hline \multicolumn{2}{|c|}{$\begin{array}{l}\text { Describe the post type (e.g., '[Status update],' '[Video]') in square brackets after } \\
\text { any description of attached content. }\end{array}$} \\
\hline \multicolumn{2}{|c|}{$\begin{array}{l}\text { Credit Facebook as the site name in the source element and then provide the } \\
\text { URL of the post. }\end{array}$} \\
\hline
\end{tabular}

\section{Webpages and websites}

\begin{tabular}{|c|c|}
\hline Type & Examples \\
\hline $\begin{array}{l}\text { Webpage on a } \\
\text { news website }\end{array}$ & $\begin{array}{l}\text { Bologna, C. (2019, October 31). Why some people with anxiety } \\
\text { love watching horror movies. HuffPost. https://bit.ly/3zZf7js } \\
\text { Roberts, N. (2020, June 10). Trayvon Martin's mother, Sybrina } \\
\text { Fulton, qualifies to run for elected office. BET News. } \\
\text { https://bet.us/3qrsLHC } \\
\text { Toner, K. (2020, September 24). When Covid-19 hit, he turned } \\
\text { his newspaper route into a lifeline for senior citizens. CNN. } \\
\text { https://cnn.it/3jjMilC } \\
\text { Parenthetical citations: (Bologna, 2019; Roberts, 2020; Toner, } \\
\text { 2020) } \\
\text { - Narrative citations: Bologna (2019), Roberts (2020), and } \\
\text { Toner (2020) }\end{array}$ \\
\hline
\end{tabular}




\section{Type}

\section{Examples}

Note:

- Use this format for articles from news websites. Common examples are BBC News, BET News, Bloomberg, CNN, HuffPost, MSNBC, Reuters, Salon, and Vox. These sites do not have associated daily or weekly newspapers.

- Use the newspaper article category for articles from newspaper websites such as The New York Times or The Washington Post.

- Provide the writer as the author.

- Provide the specific date the story was published.

- Provide the title of the news story in italics.

- List the name of the news website in the source element of the reference.

- End the reference with the URL.

\begin{tabular}{|l|l|l}
\hline $\begin{array}{l}\text { Webpage on a } \\
\text { website with } \\
\text { a government } \\
\text { agency group } \\
\text { author }\end{array}$ & $\begin{array}{l}\text { National Institute of Mental Health. (2018, July). Anxiety } \\
\text { disorders. U.S. Department of Health and Human Services, } \\
\text { National Institutes of Health. https://bit.ly/3x1bJCS }\end{array}$ \\
$\begin{array}{l}\text { - Parenthetical citations: (National Institute of Mental Health, } \\
\text { - Narrative citations: National Institute of Mental Health } \\
\text { (2018) }\end{array}$
\end{tabular}

Note:

- For a page on a government website without individual authors, use the author's specific agency responsible for the web page.

- The names of parent agencies not present in the author element appear in the source element (in the example, US Department of Health and Human Services, National Institutes of Health). This creates concise in-text citations and complete reference list entries.

- Provide as specific a date as possible for the webpage.

- Some online works note when the work was last updated. If this date is attributable to the specific content you are citing rather than the overall website, use the updated date in the reference.

- Do not include a date of the last review in a reference because content that has been reviewed has not necessarily been changed. If a date of the last review is noted on a work, ignore it for reference.

- Italicize the title of the webpage.

- End the reference with the URL. 


\begin{tabular}{|c|c|}
\hline Type & Examples \\
\hline $\begin{array}{l}\text { Webpage on } \\
\text { a website } \\
\text { with an } \\
\text { organizational } \\
\text { group author }\end{array}$ & $\begin{array}{l}\text { Mekong River Commission. (n.d.). History. } \\
\text { https://bit.ly/3w0f8Ag } \\
\text { - Parenthetical citations: ((Mekong River Commission, n.d.) } \\
\text { - Narrative citations: Mekong River Commission (n.d.) }\end{array}$ \\
\hline \multicolumn{2}{|l|}{ Note: } \\
\hline \multicolumn{2}{|c|}{$\begin{array}{l}\text { - For a page from an organization's website without individual authors, use the } \\
\text { name of the organization as the author. }\end{array}$} \\
\hline \multicolumn{2}{|c|}{$\begin{array}{l}\text { - Provide as specific a date as possible for the webpage. In the MRC case here, } \\
\text { the date is missing. }\end{array}$} \\
\hline \multicolumn{2}{|c|}{$\begin{array}{l}\text { - Some online works note when the work was last updated. If this date is } \\
\text { attributable to the specific content you are citing rather than the overall } \\
\text { website, use the updated date in the reference. }\end{array}$} \\
\hline \multicolumn{2}{|c|}{$\begin{array}{l}\text { Do not include a date of the last review in a reference because content that has } \\
\text { been reviewed has not necessarily been changed. If a date of the last review is } \\
\text { noted on a work, ignore it reference purposes. }\end{array}$} \\
\hline \multicolumn{2}{|c|}{ - Italicize the title of the webpage. } \\
\hline \multicolumn{2}{|c|}{$\begin{array}{l}\text { - Because the author of the webpage and the site name is the same, omit the site } \\
\text { name from the source element to avoid repetition. }\end{array}$} \\
\hline \multicolumn{2}{|c|}{ - End the reference with the URL. } \\
\hline $\begin{array}{l}\text { Webpage on a } \\
\text { website with a } \\
\text { retrieval date }\end{array}$ & $\begin{array}{l}\text { US Census Bureau. (n.d.). US and world population clock. US } \\
\text { Department of Commerce. Retrieved } 9 \text { January } 2020 \text { from } \\
\text { https://www.census.gov/popclock/ } \\
\text { - Parenthetical citations: (US Census Bureau, n.d.) } \\
\text { - Narrative citations: US Census Bureau (n.d.) }\end{array}$ \\
\hline \multicolumn{2}{|l|}{ Note: } \\
\hline \multicolumn{2}{|c|}{$\begin{array}{l}\text { - When page contents are designed to change over time but are not archived } \\
\text { include a retrieval date in the reference }\end{array}$} \\
\hline
\end{tabular}

Further information about APA Style Guide is available online here: https://apastyle.apa.org 


\section{BIBLIOGRAPHY}

American Psychological Association. (2020a). APA Style: Write with clarity, precision, and inclusion. Retrieved 18 May 2020, from https://apastyle.apa.org

American Psychological Association. (2020b). Publication manual of the American Psychological Association: The official guide to APA style (7th ed.). Washington, DC.

Associated Press. (2020). The Associated Press Stylebook 2020-2022 (P. Froke, A. J. Bratton, J. McMillan, P. Sarkar, J. Schwartz, \& R. Vadarevu, Eds.). New York, NY: The Associated Press.

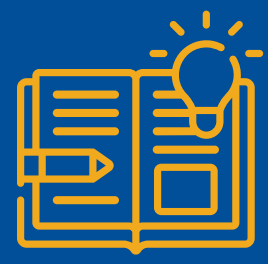

Baines, P., Egan, J., \& Jefkins, F. (2004). Public relations: contemporary issues and techniques. Boston, MA: Elsevier Butterworth-Heinemann.

European Parliament. (2018). Gender-neutral language in the European Parliament. Available at https://bit.ly/3z6HbRn

Fairfax Media. (2010). Fairfax media stylebook. Pyrmont, NSW: Fairfax Media Publications Pty Ltd.

Foster, J. (2005). Effective writing skills for public relations (3rd ed.). London: Kogan Page Limited.

MRC. (2007). A style guide for MRC publication (T. Burnhill, Ed.). Vientiane: MRC Secretariat.

Newsom, D., \& Haynes, J. (2008). Public relations writing: Form and style (8th ed.). Boston, MA: Thomson Wadsworth.

Oxford International English. (2020). The differences in British and American spelling. Retrieved on 10 June 2021 from https://bit.ly/2ZyoAAN

Penn, J. (2020). The punctuation guide: Top ten tips. Retrieved 16 April 2020 from https://www.thepunctuationguide.com/index.html

Silver, S. (2003). A media relations handbook for non-governmental organizations. New York, NY: Independent Journalism Foundation \& Media Diversity Institute.

Singh, A., \& Singh, S. (2006, Jan). What is a good editorial? Mens Sana Monographs, 4(1), 14-17. https://doi.org/10.4103/0973-1229.27600

Smith, R. D. (2003). Becoming a public relations writer: A writing process workbook for the profession (2nd ed.). New Jersey, NJ: Lawrence Erlbaum Associates, Inc.

United Nations. (2020). Guidelines for gender-inclusive language in English. Retrieved 20 May 2020, from

https://www.un.org/en/gender-inclusive-language/guidelines.shtm

University of Chicago. (2017). The Chicago Manual of Style: The essential guide for writers, editors, and publishers (The University of Chicago Press Editorial Staff, Ed.). Chicago, IL: University of Chicago Press. 


\section{ANNEXE 1: STRUCTURAL ELEMENTS OF A REPORT}

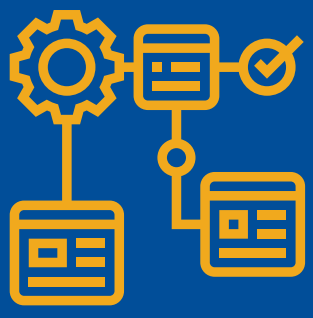


92 THE MRC WRITING, PUBLICATION \& STYLE GUIDE

Cover page

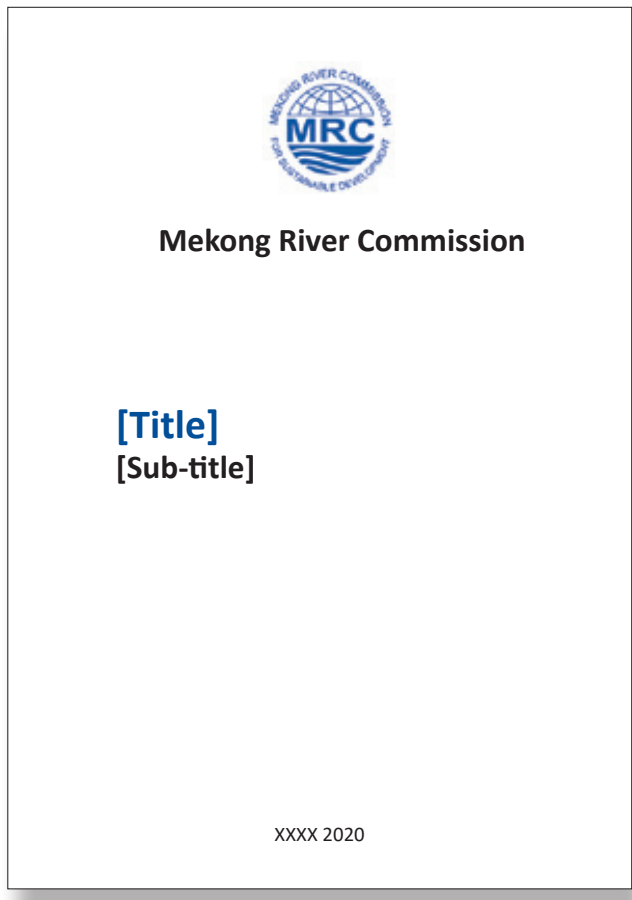

Copyright page

STANDARD COPYRIGHT

(left blank)
Contribution page

The MRC is funded by contributions from its Member Countries and Development Partners, including Australia, the European Union, Finland, Flanders/Belgium, France, Germany, Japan, Luxembourg, the Netherlands, New Zealand Sweden, Switzerland, the United States of America, and the World Bank.

\section{Citation and credits page}

Citation

Mekong River Commission. (Year).

Title of the report.

Authors

Project management (if any):

Technical experts (if any):

MRC Secretariat's technical experts (if any)

National technical experts (if any)

International technical experts (if any) 


\section{Foreword page}

FOREWORD (OR PREFACE)

Start your text here

\section{Figures page}

FIGURES (OR LIST OF FIGURES)

Use automatic list of figures to generate the list of figures here.

\section{Table of contents page}

Use automatic list of contents to

generate the table of contents here.

Start your text here

\section{Tables page}

TABLES (OR LIST OF TABLES)

Use automatic list of tables to generate the list of tables here. 
94 | THE MRC WRITING, PUBLICATION \& STYLE GUIDE

Boxes page

BOXES (OR LIST OF BOXES)

Use automatic list of boxes to generate the list of boxes here.
Abbreviations page

ABBREVIATIONS AND ACRONYMS

Start your text here.

\section{Summary page}

EXCUTIVE SUMMARY (OR SUMMARY)

Start your text here.

\section{Introduction page}

INTRODUCTION (OR SECTION 1)

This is the main body of the report. Start your text from here. 


\section{Glossary page}

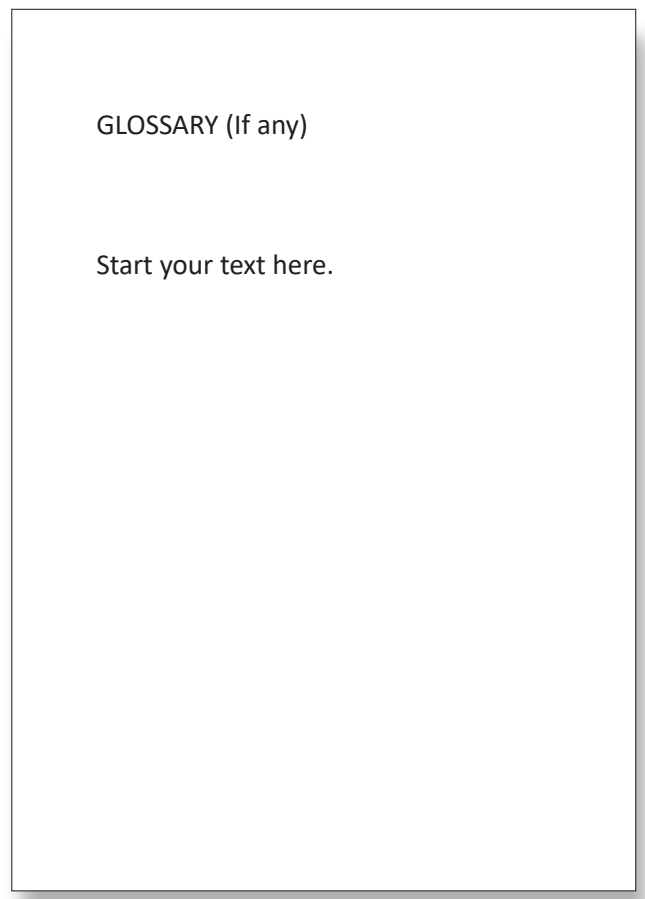

\section{References page}

\section{REFERENCES (OR BIBLIOGRAPHY)}

List all your references here by following the APA Style Guide for citation and referencing (https://apastyle.apa.org). If there are no citations in the main text but you consulted different pieces of work, list them in a bibliography here.

\section{Annexe page}

ANNEXE

List all your annexes here. The annexe should follow the same formatting, pagination, margin, and illustration requirements as the body of the document. 
ANNEXE 2:

OTHER COUNTRIES

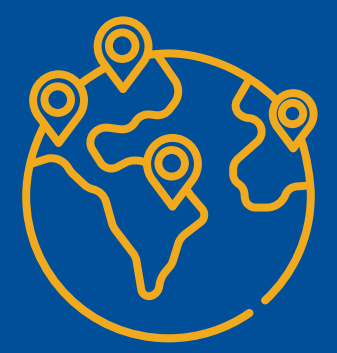


This section provides a list of other countries in alphabetical order, including their short and official names.

\begin{tabular}{|c|c|}
\hline Short name & Official name \\
\hline Afghanistan & the Islamic Republic of Afghanistan \\
\hline Albania & the Republic of Albania \\
\hline Algeria & the People's Democratic Republic of Algeria \\
\hline Andorra & the Principality of Andorra \\
\hline Angola & the Republic of Angola \\
\hline Antigua and Barbuda & Antigua and Barbuda \\
\hline Argentina & the Argentine Republic \\
\hline Armenia & the Republic of Armenia \\
\hline Australia & Australia \\
\hline Austria & the Republic of Austria \\
\hline Azerbaijan & the Republic of Azerbaijan \\
\hline Bahamas & the Commonwealth of the Bahamas \\
\hline Bahrain & the Kingdom of Bahrain \\
\hline Bangladesh & the People's Republic of Bangladesh \\
\hline Barbados & Barbados \\
\hline Belarus & the Republic of Belarus \\
\hline Belgium & the Kingdom of Belgium \\
\hline Belize & Belize \\
\hline Benin & the Republic of Benin \\
\hline Bhutan & the Kingdom of Bhutan \\
\hline $\begin{array}{l}\text { Bolivia (Plurinational State } \\
\text { of) }\end{array}$ & the Plurinational State of Bolivia \\
\hline Bosnia and Herzegovina & Bosnia and Herzegovina \\
\hline Botswana & the Republic of Botswana \\
\hline Brazil & the Federative Republic of Brazil \\
\hline Brunei Darussalam & Brunei Darussalam \\
\hline Bulgaria & the Republic of Bulgaria \\
\hline Burkina Faso & Burkina Faso \\
\hline Burundi & the Republic of Burundi \\
\hline Cabo Verde & the Republic of Cabo Verde \\
\hline Cameroon & the Republic of Cameroon \\
\hline Canada & Canada \\
\hline Central African Republic & the Central African Republic \\
\hline Chad & the Republic of Chad \\
\hline Chile & the Republic of Chile \\
\hline
\end{tabular}




\begin{tabular}{|c|c|}
\hline Short name & Official name \\
\hline China & the People's Republic of China \\
\hline Colombia & the Republic of Colombia \\
\hline Comoros & the Union of the Comoros \\
\hline Congo & the Republic of the Congo \\
\hline Cook Islands & the Cook Islands \\
\hline Costa Rica & the Republic of Costa Rica \\
\hline Croatia & the Republic of Croatia \\
\hline Cuba & the Republic of Cuba \\
\hline Cyprus & the Republic of Cyprus \\
\hline Czechia & the Czech Republic \\
\hline Côte d'Ivoire & the Republic of Côte d'Ivoire \\
\hline $\begin{array}{l}\text { Democratic People's } \\
\text { Republic of Korea }\end{array}$ & the Democratic People's Republic of Korea \\
\hline $\begin{array}{l}\text { Democratic Republic } \\
\text { of the Congo }\end{array}$ & the Democratic Republic of the Congo \\
\hline Denmark & the Kingdom of Denmark \\
\hline Djibouti & the Republic of Djibouti \\
\hline Dominica & the Commonwealth of Dominica \\
\hline Dominican Republic & the Dominican Republic \\
\hline Ecuador & the Republic of Ecuador \\
\hline Egypt & the Arab Republic of Egypt \\
\hline El Salvador & the Republic of El Salvador \\
\hline Equatorial Guinea & the Republic of Equatorial Guinea \\
\hline Eritrea & the State of Eritrea \\
\hline Estonia & the Republic of Estonia \\
\hline Eswatini & the Kingdom of Eswatini \\
\hline Ethiopia & the Federal Democratic Republic of Ethiopia \\
\hline Faroe Islands & the Faroe Islands \\
\hline Fiji & the Republic of Fiji \\
\hline Finland & the Republic of Finland \\
\hline France & the French Republic \\
\hline Gabon & the Gabonese Republic \\
\hline Gambia & the Republic of the Gambia \\
\hline Georgia & Georgia \\
\hline Germany & the Federal Republic of Germany \\
\hline Ghana & the Republic of Ghana \\
\hline Greece & the Hellenic Republic \\
\hline
\end{tabular}




\begin{tabular}{|c|c|}
\hline Short name & Official name \\
\hline Grenada & Grenada \\
\hline Guatemala & the Republic of Guatemala \\
\hline Guinea & the Republic of Guinea \\
\hline Guinea-Bissau & the Republic of Guinea-Bissau \\
\hline Guyana & the Co-operative Republic of Guyana \\
\hline Haiti & the Republic of Haiti \\
\hline Honduras & the Republic of Honduras \\
\hline Hong Kong & $\begin{array}{l}\text { the Hong Kong Special Administrative Region } \\
\text { of the People's Republic of China }\end{array}$ \\
\hline Hungary & Hungary \\
\hline Iceland & the Republic of Iceland \\
\hline India & the Republic of India \\
\hline Indonesia & the Republic of Indonesia \\
\hline Iran (Islamic Republic of) & the Islamic Republic of Iran \\
\hline Iraq & the Republic of Iraq \\
\hline Ireland & Ireland \\
\hline Israel & the State of Israel \\
\hline Italy & the Republic of Italy \\
\hline Jamaica & Jamaica \\
\hline Japan & Japan \\
\hline Jordan & the Hashemite Kingdom of Jordan \\
\hline Kazakhstan & the Republic of Kazakhstan \\
\hline Kenya & the Republic of Kenya \\
\hline Kiribati & the Republic of Kiribati \\
\hline Kuwait & the State of Kuwait \\
\hline Kyrgyzstan & the Kyrgyz Republic \\
\hline Latvia & the Republic of Latvia \\
\hline Lebanon & the Lebanese Republic \\
\hline Lesotho & the Kingdom of Lesotho \\
\hline Liberia & the Republic of Liberia \\
\hline Libya & the State of Libya \\
\hline Lithuania & the Republic of Lithuania \\
\hline Luxembourg & the Grand Duchy of Luxembourg \\
\hline Madagascar & the Republic of Madagascar \\
\hline Malawi & the Republic of Malawi \\
\hline Malaysia & Malaysia \\
\hline
\end{tabular}




\begin{tabular}{|c|c|}
\hline Short name & Official name \\
\hline Maldives & the Republic of Maldives \\
\hline Mali & the Republic of Mali \\
\hline Malta & the Republic of Malta \\
\hline Marshall Islands & the Republic of the Marshall Islands \\
\hline Mauritania & the Islamic Republic of Mauritania \\
\hline Mauritius & the Republic of Mauritius \\
\hline Mexico & the United Mexican States \\
\hline $\begin{array}{l}\text { Micronesia (Federated } \\
\text { States of) }\end{array}$ & the Federated States of Micronesia \\
\hline Monaco & the Principality of Monaco \\
\hline Mongolia & Mongolia \\
\hline Montenegro & Montenegro \\
\hline Morocco & the Kingdom of Morocco \\
\hline Mozambique & the Republic of Mozambique \\
\hline Myanmar & the Republic of the Union of Myanmar \\
\hline Namibia & the Republic of Namibia \\
\hline Nauru & the Republic of Nauru \\
\hline Nepal & the Federal Democratic Republic of Nepal \\
\hline Netherlands & the Kingdom of the Netherlands \\
\hline New Zealand & New Zealand \\
\hline Nicaragua & the Republic of Nicaragua \\
\hline Niger & the Republic of the Niger \\
\hline Nigeria & the Federal Republic of Nigeria \\
\hline Niue & Niue \\
\hline North Macedonia & the Republic of North Macedonia \\
\hline Norway & the Kingdom of Norway \\
\hline Oman & the Sultanate of Oman \\
\hline Pakistan & the Islamic Republic of Pakistan \\
\hline Palau & the Republic of Palau \\
\hline Panama & the Republic of Panama \\
\hline Papua New Guinea & Independent State of Papua New Guinea \\
\hline Paraguay & the Republic of Paraguay \\
\hline Peru & the Republic of Peru \\
\hline Philippines & the Republic of the Philippines \\
\hline Poland & the Republic of Poland \\
\hline Portugal & the Portuguese Republic \\
\hline
\end{tabular}




\begin{tabular}{|c|c|}
\hline Short name & Official name \\
\hline Qatar & the State of Qatar \\
\hline Republic of Korea & the Republic of Korea \\
\hline Republic of Moldova & the Republic of Moldova \\
\hline Romania & Romania \\
\hline Russian Federation & the Russian Federation \\
\hline Rwanda & the Republic of Rwanda \\
\hline Saint Kitts and Nevis & Saint Kitts and Nevis \\
\hline Saint Lucia & Saint Lucia \\
\hline $\begin{array}{l}\text { Saint Vincent and the } \\
\text { Grenadines }\end{array}$ & Saint Vincent and the Grenadines \\
\hline Samoa & the Independent State of Samoa \\
\hline San Marino & the Republic of San Marino \\
\hline Sao Tome and Principe & $\begin{array}{l}\text { the Democratic Republic of Sao Tome and } \\
\text { Principe }\end{array}$ \\
\hline Saudi Arabia & the Kingdom of Saudi Arabia \\
\hline Senegal & the Republic of Senegal \\
\hline Serbia & the Republic of Serbia \\
\hline Seychelles & the Republic of Seychelles \\
\hline Sierra Leone & the Republic of Sierra Leone \\
\hline Singapore & the Republic of Singapore \\
\hline Slovakia & the Slovak Republic \\
\hline Slovenia & the Republic of Slovenia \\
\hline Solomon Islands & Solomon Islands \\
\hline Somalia & the Federal Republic of Somalia \\
\hline South Africa & the Republic of South Africa \\
\hline South Sudan & the Republic of South Sudan \\
\hline Spain & the Kingdom of Spain \\
\hline Sri Lanka & the Democratic Socialist Republic of Sri Lanka \\
\hline Sudan & the Republic of the Sudan \\
\hline Suriname & the Republic of Suriname \\
\hline Sweden & the Kingdom of Sweden \\
\hline Switzerland & the Swiss Confederation \\
\hline Syrian Arab Republic & the Syrian Arab Republic \\
\hline Tajikistan & the Republic of Tajikistan \\
\hline Timor-Leste & the Democratic Republic of Timor-Leste \\
\hline Taiwan & $\begin{array}{l}\text { the People's Republic of China or Chinese } \\
\text { Taipei }\end{array}$ \\
\hline
\end{tabular}


102 | THE MRC WRITING, PUBLICATION \& STYLE GUIDE

\begin{tabular}{|l|l|} 
Short name & Official name \\
\hline Togo & Tokelau \\
\hline Tokelau & the Kingdom of Tonga \\
\hline Tonga & the Republic of Trinidad and Tobago \\
\hline Trinidad and Tobago & the Republic of Tunisia \\
\hline Tunisia & the Republic of Turkey \\
\hline Turkey & Turkmenistan \\
\hline Turkmenistan & Tuvalu \\
\hline Tuvalu & the Republic of Uganda \\
\hline Uganda & Ukraine \\
\hline Ukraine & the United Arab Emirates \\
\hline United Arab Emirates & the United Kingdom of Great Britain and \\
\hline United Kingdom of Great \\
Britain and Northern & Northern Ireland \\
\hline Ireland & the United Republic of Tanzania \\
\hline United Republic of Tanzania & the United States of America \\
\hline United States of America & the Eastern Republic of Uruguay \\
\hline Uruguay & the Republic of Uzbekistan \\
\hline Uzbekistan & the Republic of Vanuatu \\
\hline Vanuatu & the Bolivarian Republic of Venezuela \\
\hline Venezuela (Bolivarian \\
Republic of) & the Republic of Yemen \\
\hline Yemen & the Republic of Zambia \\
\hline Zambia & the Republic of Zimbabwe \\
\hline Zimbabwe & \\
\hline & the \\
\hline
\end{tabular}




\section{ANNEXE 3: NAMES OF PLACES AND GEOGRAPHIC FEATURES}




\section{Cambodia}

\begin{tabular}{|c|c|c|}
\hline $\begin{array}{l}\text { Province and/ } \\
\text { or city }\end{array}$ & District and/or municipality & \\
\hline $\begin{array}{l}\text { Banteay } \\
\text { Meanchey }\end{array}$ & $\begin{array}{l}\text { Mongkol Borei } \\
\text { Phnom Srok } \\
\text { Preah Net Preah } \\
\text { Ou Chrov } \\
\text { Serei Saophoan Municipality }\end{array}$ & $\begin{array}{l}\text { Thma Puok } \\
\text { Svay Chek } \\
\text { Malai } \\
\text { Poipet Municipality }\end{array}$ \\
\hline Battambang & $\begin{array}{l}\text { Banan } \\
\text { Thma Koul } \\
\text { Battambang Municipality } \\
\text { Bavel } \\
\text { Aek Phnum } \\
\text { Moung Ruessei } \\
\text { Rotanak Mondol }\end{array}$ & $\begin{array}{l}\text { Sangkae } \\
\text { Samlout } \\
\text { Sampov Loun } \\
\text { Phnum Proek } \\
\text { Kamrieng } \\
\text { Koas Krala } \\
\text { Rukhak Kiri } \\
\end{array}$ \\
\hline Kampot & $\begin{array}{l}\text { Angkor Chey } \\
\text { Banteay Meas } \\
\text { Chhouk } \\
\text { Chum Kiri } \\
\text { Dang Tong } \\
\end{array}$ & $\begin{array}{l}\text { Kampong Trach } \\
\text { Tuek Chhou } \\
\text { Kampot Municipality } \\
\text { Bouk Kou Municipality }\end{array}$ \\
\hline Kandal & $\begin{array}{l}\text { Kandal Stueng } \\
\text { Kien Svay } \\
\text { Khsach Kandal } \\
\text { Koh Thum } \\
\text { Leuk Daek } \\
\text { Lvea Aem }\end{array}$ & $\begin{array}{l}\text { Mukh Kampul } \\
\text { Angk Snuol } \\
\text { Ponhea Lueu } \\
\text { S'ang } \\
\text { Ta Khmau Municipality }\end{array}$ \\
\hline Kep & Damnak Chang'aeur & Kep Municipality \\
\hline Koh Kong & $\begin{array}{l}\text { Botum Sakor } \\
\text { Kiri Sakor } \\
\text { Khemarak Phoumin } \\
\text { Municipality } \\
\text { Smach Mean Chey }\end{array}$ & $\begin{array}{l}\text { Mondol Seima } \\
\text { Srae Ambel } \\
\text { Thma Bang }\end{array}$ \\
\hline Kompong Cham & $\begin{array}{l}\text { Batheay } \\
\text { Chamkar Leu } \\
\text { Cheung Prey } \\
\text { Kampong Cham Municipality } \\
\text { Kampong Siem }\end{array}$ & $\begin{array}{l}\text { Kang Meas } \\
\text { Koh Sotin } \\
\text { Prey Chhor } \\
\text { Srey Santhor } \\
\text { Stueng Trang }\end{array}$ \\
\hline $\begin{array}{l}\text { Kompong } \\
\text { Chhnang }\end{array}$ & $\begin{array}{l}\text { Baribour } \\
\text { Chol Kiri } \\
\text { Kampong Chhnang } \\
\text { Municipality } \\
\text { Kampong Leaeng }\end{array}$ & $\begin{array}{l}\text { Kampong Tralach } \\
\text { Rolea Ph'ear } \\
\text { Samaki Mean Chey } \\
\text { Tuek Phos }\end{array}$ \\
\hline
\end{tabular}




\begin{tabular}{|c|c|c|}
\hline $\begin{array}{l}\text { Province and/ } \\
\text { or city }\end{array}$ & District and/or municipality & \\
\hline Kompong Speu & $\begin{array}{l}\text { Basedth } \\
\text { Chbar Mon Municipality } \\
\text { Kong Pisei } \\
\text { Aoral }\end{array}$ & $\begin{array}{l}\text { Odong } \\
\text { Phnom Sruoch } \\
\text { Samraong Tong } \\
\text { Thpong }\end{array}$ \\
\hline Kompong Thom & $\begin{array}{l}\text { Baray } \\
\text { Kampong Svay } \\
\text { Stueng Sen Municipality } \\
\text { Prasat Balangk } \\
\text { Prasat Sambour }\end{array}$ & $\begin{array}{l}\text { Sandaan } \\
\text { Santuk } \\
\text { Stoung } \\
\text { Taing Kouk }\end{array}$ \\
\hline Kratie & $\begin{array}{l}\text { Chhloung } \\
\text { Kratie Municipality } \\
\text { Prek Prasab }\end{array}$ & $\begin{array}{l}\text { Sambour } \\
\text { Snuol } \\
\text { Chet Borei }\end{array}$ \\
\hline Mondolkiri & $\begin{array}{l}\text { Keo Seima } \\
\text { Kaoh Nheaek } \\
\text { Ou Reang } \\
\end{array}$ & $\begin{array}{l}\text { Pech Chenda } \\
\text { Sen Monorom } \\
\text { Municipality }\end{array}$ \\
\hline $\begin{array}{l}\text { Oddar } \\
\text { Meanchey }\end{array}$ & $\begin{array}{l}\text { Anlong Veng } \\
\text { Banteay Ampil } \\
\text { Chong Kal }\end{array}$ & $\begin{array}{l}\text { Samraong Municipality } \\
\text { Trapeang Prasat }\end{array}$ \\
\hline Pailin & Pailin Municipality & Sala Krauv \\
\hline Phnom Penh & $\begin{array}{l}\text { Chamkar Mon } \\
\text { Doun Penh } \\
\text { Prampir Makara } \\
\text { Tuol Kork } \\
\text { Dangkor } \\
\text { Mean Chey } \\
\text { Russey Keo }\end{array}$ & $\begin{array}{l}\text { Sen Sok } \\
\text { Pou Senchey } \\
\text { Chroy Changvar } \\
\text { Prek Pnov } \\
\text { Chbar Ampov } \\
\text { Boeng Keng Kang } \\
\text { Kamboul }\end{array}$ \\
\hline Preah Sihanouk & $\begin{array}{l}\text { Preah Sihanouk Municipality } \\
\text { Prey Nob } \\
\text { Stueng Hav }\end{array}$ & $\begin{array}{l}\text { Kampong Seila } \\
\text { Koh Rong }\end{array}$ \\
\hline Preah Vihear & $\begin{array}{l}\text { Chey Sen } \\
\text { Chhaeb } \\
\text { Choam Khsant } \\
\text { Kuleaen }\end{array}$ & $\begin{array}{l}\text { Rovieng } \\
\text { Sangkum Thmei } \\
\text { Tbaeng Mean Chey } \\
\text { Preah Vihear } \\
\text { Municipality }\end{array}$ \\
\hline Prey Veng & $\begin{array}{l}\text { Ba Phnum } \\
\text { Kamchay Mear } \\
\text { Kampong Trabaek } \\
\text { Kanhchriech } \\
\text { Me Sang } \\
\text { Peam Chor } \\
\text { Peam Ro }\end{array}$ & $\begin{array}{l}\text { Pea Reang } \\
\text { Preah Sdach } \\
\text { Prey Veng Municipality } \\
\text { Pea Rieng } \\
\text { Sithor Kandal } \\
\text { Svay Antor }\end{array}$ \\
\hline
\end{tabular}




\begin{tabular}{|c|c|c|}
\hline $\begin{array}{l}\text { Province and/ } \\
\text { or city }\end{array}$ & District and/or municipality & \\
\hline Pursat & $\begin{array}{l}\text { Bakan } \\
\text { Kandieng } \\
\text { Krakor } \\
\text { Phnum Kravanh }\end{array}$ & $\begin{array}{l}\text { Pursat Municipality } \\
\text { Veal Veaeng } \\
\text { Talou Sen Chey }\end{array}$ \\
\hline Ratanakiri & $\begin{array}{l}\text { Andoung Meas } \\
\text { Banlung Municipality } \\
\text { Bar Keav } \\
\text { Koun Mom } \\
\text { Lumphat }\end{array}$ & $\begin{array}{l}\text { Ou Chum } \\
\text { Ou Ya Dav } \\
\text { Ta Veaeng } \\
\text { Veun Sai }\end{array}$ \\
\hline Siem Reap & $\begin{array}{l}\text { Angkor Chum } \\
\text { Angkor Thom } \\
\text { Banteay Srei } \\
\text { Chi Kraeng } \\
\text { Kralanh } \\
\text { Puok }\end{array}$ & $\begin{array}{l}\text { Prasat Bakong } \\
\text { Siem Reap Municipality } \\
\text { Sout Nikom } \\
\text { Srei Snam } \\
\text { Svay Leu } \\
\text { Varin }\end{array}$ \\
\hline Steung Treng & $\begin{array}{l}\text { Sesan } \\
\text { Siem Bouk } \\
\text { Siem Pang }\end{array}$ & $\begin{array}{l}\text { Stung Treng Municipality } \\
\text { Thala Barivat } \\
\text { Borei O-Svay Sen Chey }\end{array}$ \\
\hline Svay Rieng & $\begin{array}{l}\text { Chantrea } \\
\text { Kampong Rou } \\
\text { Rumduol } \\
\text { Romeas Haek }\end{array}$ & $\begin{array}{l}\text { Svay Chrum } \\
\text { Svay Rieng Municipality } \\
\text { Svay Teab } \\
\text { Bavet Municipality }\end{array}$ \\
\hline Takeo & $\begin{array}{l}\text { Angkor Borei } \\
\text { Bati } \\
\text { Borei Cholsar } \\
\text { Kiri Vong } \\
\text { Koh Andaet }\end{array}$ & $\begin{array}{l}\text { Prey Kabbas } \\
\text { Samraong } \\
\text { Doun Keo Municipality } \\
\text { Tram Kak } \\
\text { Treang }\end{array}$ \\
\hline Tboung Khmum & $\begin{array}{l}\text { Dambae } \\
\text { Krouch Chhmar } \\
\text { Memot } \\
\text { Ou Reang Ov }\end{array}$ & $\begin{array}{l}\text { Ponhea Kraek } \\
\text { Suong Municipality } \\
\text { Tboung Khmum }\end{array}$ \\
\hline
\end{tabular}

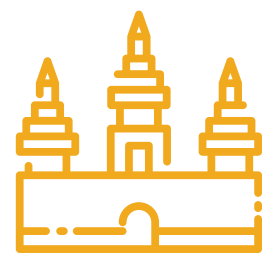




\section{Lao PDR}

\begin{tabular}{|l|l|}
\hline Province & City \\
\hline Attapeu & Saysettha \\
\hline Bokeo & Huay Xay \\
\hline Bolikhamxay & Paksan \\
\hline Champassak & Pakse \\
\hline Huaphanh & Samneua \\
\hline Khammuane & Thakhek \\
\hline Luang Namtha & Namtha \\
\hline Luang Prabang & Luang Prabang \\
\hline Oudomxay & Muang Xay \\
\hline Phongsaly & Boun Neua \\
\hline Salavan & Salavan \\
\hline Savannakhet & Kaysone \\
\hline Sekong & Lamam \\
\hline Vientiane (Prefecture) & Vientiane Capital \\
\hline Vientiane (Province) & Viengkham \\
\hline Xayaburi & Xayaburi \\
\hline Xaysomboun & Anouvong \\
\hline Xiengkhuang & Phonsavan \\
\hline
\end{tabular}

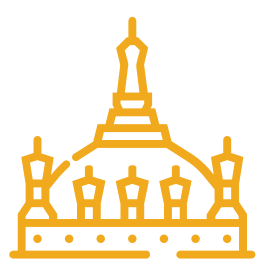




\section{Thailand}

\begin{tabular}{|c|c|c|}
\hline $\begin{array}{l}\text { Province/special } \\
\text { administrative area }\end{array}$ & \multicolumn{2}{|l|}{ Districts } \\
\hline \multicolumn{3}{|c|}{ Bangkok Metropolitan Region } \\
\hline Bangkok & $\begin{array}{l}\text { Phra Nakhon } \\
\text { Dusit } \\
\text { Nong Chok } \\
\text { Bang Rak } \\
\text { Bang Khen } \\
\text { Bang Kapi } \\
\text { Pathum Wan } \\
\text { Pom Prap Sattru Phai } \\
\text { Phra Khanong } \\
\text { Min Buri } \\
\text { Lat Krabang } \\
\text { Yan Nawa } \\
\text { Samphanthawong } \\
\text { Phaya Thai } \\
\text { Thon Buri } \\
\text { Bangkok Yai } \\
\text { Huai Khwang } \\
\text { Khlong San } \\
\text { Taling Chan } \\
\text { Bangkok Noi } \\
\text { Bang Khun Thian } \\
\text { Phasi Charoen } \\
\text { Nong Khaem } \\
\text { Rat Burana } \\
\text { Bang Phlat }\end{array}$ & $\begin{array}{l}\text { Din Daeng } \\
\text { Bueng Kum } \\
\text { Sathon } \\
\text { Bang Sue } \\
\text { Chatuchak } \\
\text { Bang Kho Laem } \\
\text { Prawet } \\
\text { Khlong Toei } \\
\text { Suang Luang } \\
\text { Chom Thong } \\
\text { Don Mueang } \\
\text { Ratchathewi } \\
\text { Lat Phrao } \\
\text { Watthana } \\
\text { Bang Khae } \\
\text { Lak Si } \\
\text { Sai Mai } \\
\text { Khan Na Yao } \\
\text { Saphan Sung } \\
\text { Wang Thonglang } \\
\text { Khlong Sam Wa } \\
\text { Bang Na } \\
\text { Thawi Watthana } \\
\text { Thung Khru } \\
\text { Bang Bon }\end{array}$ \\
\hline Nakhon Pathom & $\begin{array}{l}\text { Mueang Nakhon Pathom } \\
\text { Khamphaeng Saen } \\
\text { Nakhon Chai Si } \\
\text { Don Tum }\end{array}$ & $\begin{array}{l}\text { Bang Len } \\
\text { Sam Phran } \\
\text { Phutthamonthon }\end{array}$ \\
\hline Nonthaburi & $\begin{array}{l}\text { Mueang Nonthaburi } \\
\text { Bang Kruai } \\
\text { Bang Yai }\end{array}$ & $\begin{array}{l}\text { Bang Bua Thong } \\
\text { Sai Noi } \\
\text { Pak Kret }\end{array}$ \\
\hline Pathum Thani & $\begin{array}{l}\text { Mueang Pathum Thani } \\
\text { Khlong Luang } \\
\text { Thanyaburi } \\
\text { Nong Suea }\end{array}$ & $\begin{array}{l}\text { Lat Lum Kaeo } \\
\text { Lam Luk Ka } \\
\text { Sam Khok }\end{array}$ \\
\hline Samut Prakan & $\begin{array}{l}\text { Mueang Samut Prakan } \\
\text { Bang Bo } \\
\text { Bang Phli }\end{array}$ & $\begin{array}{l}\text { Phra Pradaeng } \\
\text { Phra Samut Chedi } \\
\text { Bang Sao Thong }\end{array}$ \\
\hline
\end{tabular}




\begin{tabular}{|c|c|c|}
\hline $\begin{array}{l}\text { Province/special } \\
\text { administrative area }\end{array}$ & \multicolumn{2}{|l|}{ Districts } \\
\hline Samut Sakhon & $\begin{array}{l}\text { Mueang Samut Sakhon } \\
\text { Krathum Baen }\end{array}$ & Ban Phaeo \\
\hline \multicolumn{3}{|l|}{ Central } \\
\hline Ang Thong & $\begin{array}{l}\text { Mueang Ang Thong } \\
\text { Chaiyo } \\
\text { Pa Mok } \\
\text { Pho Thong }\end{array}$ & $\begin{array}{l}\text { Sawaeng Ha } \\
\text { Wiset Chai Chan } \\
\text { Samko }\end{array}$ \\
\hline Chai Nat & $\begin{array}{l}\text { Mueang Chai Nat } \\
\text { Manorom } \\
\text { Wat Sing } \\
\text { Sapphaya }\end{array}$ & $\begin{array}{l}\text { Sankhaburi } \\
\text { Hankha } \\
\text { Nong Mamong } \\
\text { Noen Kham }\end{array}$ \\
\hline Lopburi & $\begin{array}{l}\text { Mueang Lopburi } \\
\text { Phatthana Nikhom } \\
\text { Khok Samrong } \\
\text { Chai Badan } \\
\text { Tha Wung } \\
\text { Ban Mi }\end{array}$ & $\begin{array}{l}\text { Tha Luang } \\
\text { Sa Bot } \\
\text { Khok Charoen } \\
\text { Lam Sonthi } \\
\text { Nong Muang }\end{array}$ \\
\hline $\begin{array}{l}\text { Phra Nakhon Si } \\
\text { Ayutthaya }\end{array}$ & $\begin{array}{l}\text { Phra Nakhon Si } \\
\text { Ayutthaya } \\
\text { Tha Ruea } \\
\text { Nakhon Luang } \\
\text { Bang Sai } \\
\text { Bang Ban } \\
\text { Bang Pa-in } \\
\text { Bang Pahan } \\
\text { Phak Hai }\end{array}$ & $\begin{array}{l}\text { Phachi } \\
\text { Lat Bua Luang } \\
\text { Wang Noi } \\
\text { Sena } \\
\text { Bang Sai } \\
\text { Uthai } \\
\text { Maha Rat } \\
\text { Ban Phraek }\end{array}$ \\
\hline Saraburi & $\begin{array}{l}\text { Mueang Saraburi } \\
\text { Kaeng Koi } \\
\text { Nong Khae } \\
\text { Wihan Daeng } \\
\text { Nong Saeng } \\
\text { Ban Mo } \\
\text { Don Phut }\end{array}$ & $\begin{array}{l}\text { Nong Don } \\
\text { Phra Phutthabat } \\
\text { Sao Hai } \\
\text { Muak Lek } \\
\text { Wang Muang } \\
\text { Chaloem Phra Kiat }\end{array}$ \\
\hline Sing Buri & $\begin{array}{l}\text { Mueang Sing Buri } \\
\text { Bang Rachan } \\
\text { Khai Bang Rachan }\end{array}$ & $\begin{array}{l}\text { Phrom Buri } \\
\text { Tha Chang } \\
\text { In Buri }\end{array}$ \\
\hline
\end{tabular}




\begin{tabular}{|c|c|c|}
\hline $\begin{array}{l}\text { Province/special } \\
\text { administrative area }\end{array}$ & \multicolumn{2}{|l|}{ Districts } \\
\hline \multicolumn{3}{|l|}{ Eastern } \\
\hline Chachoengsao & $\begin{array}{l}\text { Mueang Chachoengsao } \\
\text { Bang Khla } \\
\text { Bang Nam Priao } \\
\text { Bang Pakong } \\
\text { Ban Pho } \\
\text { Phanom Sarakham }\end{array}$ & $\begin{array}{l}\text { Ratchasan } \\
\text { Sanam Chai Khet } \\
\text { Plaeng Yao } \\
\text { Tha Takiap } \\
\text { Khlong Khuean }\end{array}$ \\
\hline Chanthaburi & $\begin{array}{l}\text { Mueang Chanthaburi } \\
\text { Khlung } \\
\text { Tha Mai } \\
\text { Pong Nam Ron } \\
\text { Makham }\end{array}$ & $\begin{array}{l}\text { Laem Sing } \\
\text { Soi Dao } \\
\text { Kaeng Hang Maeo } \\
\text { Na Yai Am } \\
\text { Khao Khitchakut }\end{array}$ \\
\hline Chonburi & $\begin{array}{l}\text { Mueang Chonburi } \\
\text { Ban Beung } \\
\text { Nong Yai } \\
\text { Bang Lamung } \\
\text { Phan Thong } \\
\text { Phanat Nikhom }\end{array}$ & $\begin{array}{l}\text { Si Racha } \\
\text { Ko Sichang } \\
\text { Sattahip } \\
\text { Bo Thong } \\
\text { Ko Chan }\end{array}$ \\
\hline Nakhon Nayok & $\begin{array}{l}\text { Mueang Nakhon Nayok } \\
\text { Pak Phli }\end{array}$ & $\begin{array}{l}\text { Ban Na } \\
\text { Ongkharak }\end{array}$ \\
\hline Prachinburi & $\begin{array}{l}\text { Mueang Prachinburi } \\
\text { Kabin Buri } \\
\text { Na Di } \\
\text { Ban Sang }\end{array}$ & $\begin{array}{l}\text { Prachantakham } \\
\text { Si Maha Phot } \\
\text { Si Mahosot }\end{array}$ \\
\hline Rayong & $\begin{array}{l}\text { Mueang Rayong } \\
\text { Ban Chang } \\
\text { Klaeng } \\
\text { Wang Chan }\end{array}$ & $\begin{array}{l}\text { Ban Khai } \\
\text { Pluak Daeng } \\
\text { Khao Chamao } \\
\text { Nikhom Phatthana }\end{array}$ \\
\hline Sa Kaeo & $\begin{array}{l}\text { Mueang Sa Kaeo } \\
\text { Khlong Hat } \\
\text { Ta Phraya } \\
\text { Wang Nam Yen } \\
\text { Watthana Nakhon }\end{array}$ & $\begin{array}{l}\text { Aranyaprathet } \\
\text { Khao Chakan } \\
\text { Khok Sung } \\
\text { Wang Sombun }\end{array}$ \\
\hline Trat & $\begin{array}{l}\text { Mueang Trat } \\
\text { Khlong Yai } \\
\text { Khao Saming } \\
\text { Bo Rai }\end{array}$ & $\begin{array}{l}\text { Laem Ngop } \\
\text { Ko Kut } \\
\text { Ko Chang }\end{array}$ \\
\hline \multicolumn{3}{|l|}{ Northeastern } \\
\hline Amnat Charoen & $\begin{array}{l}\text { Mueang Amnat Charoen } \\
\text { Chanuman } \\
\text { Pathum Ratchawongsa } \\
\text { Phana }\end{array}$ & $\begin{array}{l}\text { Senangkhanikhom } \\
\text { Hua Taphan } \\
\text { Lue Amnat }\end{array}$ \\
\hline
\end{tabular}




\begin{tabular}{|c|c|c|}
\hline $\begin{array}{l}\text { Province/special } \\
\text { administrative area }\end{array}$ & Districts & \\
\hline Bueng Kan & $\begin{array}{l}\text { Mueang Bueng Kan } \\
\text { Phon Charoen } \\
\text { So Phisai } \\
\text { Seka }\end{array}$ & $\begin{array}{l}\text { Pak Khat } \\
\text { Bueng Khong Long } \\
\text { Si Wilai } \\
\text { Bung Khla }\end{array}$ \\
\hline Buriram & $\begin{array}{l}\text { Mueang Buriram } \\
\text { Khu Mueang } \\
\text { Krasang } \\
\text { Nang Rong } \\
\text { Nong Ki } \\
\text { Lahan Sai } \\
\text { Prakhon Chai } \\
\text { Ban Kruat } \\
\text { Phutthaisong } \\
\text { Lam Plai Mat } \\
\text { Satuek } \\
\text { Pakham }\end{array}$ & $\begin{array}{l}\text { Na Pho } \\
\text { Nong Hong } \\
\text { Phlapphla Chai } \\
\text { Huai Rat } \\
\text { Non Suwan } \\
\text { Chamni } \\
\text { Ban Mai Chaiyaphot } \\
\text { Non Din Daeng } \\
\text { Ban Dan } \\
\text { Khaen Dong } \\
\text { Chaloem Phra Kiat }\end{array}$ \\
\hline Chaiyaphum & $\begin{array}{l}\text { Mueang Chaiyaphum } \\
\text { Ban Khwao } \\
\text { Khon Sawan } \\
\text { Kaset Sombun } \\
\text { Nong Bua Daeng } \\
\text { Chatturat } \\
\text { Bamnet Narong } \\
\text { Nong Bua Rawe }\end{array}$ & $\begin{array}{l}\text { Thep Sathit } \\
\text { Phu Khiao } \\
\text { Ban Thaen } \\
\text { Kaeng Khro } \\
\text { Khon San } \\
\text { Phakdi Chumphon } \\
\text { Noen Sa-nga } \\
\text { Sap Yai }\end{array}$ \\
\hline Kalasin & $\begin{array}{l}\text { Mueang Kalasin } \\
\text { Na Mon } \\
\text { Kamalasai } \\
\text { Rong Kham } \\
\text { Kuchinarai } \\
\text { Khao Wong } \\
\text { Yang Talat } \\
\text { Huai Mek } \\
\text { Sahatsakhan }\end{array}$ & $\begin{array}{l}\text { Kham Muang } \\
\text { Tha Khantho } \\
\text { Nong Kung Si } \\
\text { Somdet } \\
\text { Huai Phueng } \\
\text { Sam Chai } \\
\text { Na Khu } \\
\text { Don Chan } \\
\text { Khong Chai }\end{array}$ \\
\hline
\end{tabular}




\begin{tabular}{|c|c|c|}
\hline $\begin{array}{l}\text { Province/special } \\
\text { administrative area }\end{array}$ & \multicolumn{2}{|l|}{ Districts } \\
\hline Khon Kaen & $\begin{array}{l}\text { Mueang Khon Kaen } \\
\text { Ban Fang } \\
\text { Phra Yuen } \\
\text { Nong Ruea } \\
\text { Chum Phae } \\
\text { Si Chomphu } \\
\text { Nam Phong } \\
\text { Ubolratana } \\
\text { Kranuan } \\
\text { Ban Phai } \\
\text { Pueai Noi } \\
\text { Phon } \\
\text { Waeng Yai }\end{array}$ & $\begin{array}{l}\text { Waeng Noi } \\
\text { Nong Song Hong } \\
\text { Phu Wiang } \\
\text { Mancha Khiri } \\
\text { Chonnabot } \\
\text { Khao Suan Kwang } \\
\text { Phu Pha Man } \\
\text { Sam Sung } \\
\text { Khok Pho Chai } \\
\text { Nong Na Kham } \\
\text { Ban Haet } \\
\text { Non Sila } \\
\text { Wiang Kao }\end{array}$ \\
\hline Loei & $\begin{array}{l}\text { Mueang Loei } \\
\text { Na Duang } \\
\text { Chiang Khan } \\
\text { Pak Chom } \\
\text { Dan Sai } \\
\text { Na Haeo } \\
\text { Phu Ruea }\end{array}$ & $\begin{array}{l}\text { Tha Li } \\
\text { Wang Saphung } \\
\text { Phu Kradueng } \\
\text { Phu Luang } \\
\text { Pha Khao } \\
\text { Erawan } \\
\text { Nong Hin }\end{array}$ \\
\hline Maha Sarakham & $\begin{array}{l}\text { Mueang Maha Sarakham } \\
\text { Kae Dam } \\
\text { Kosum Phisai } \\
\text { Kantharawichai } \\
\text { Chiang Yuen } \\
\text { Borabue } \\
\text { Na Chueak }\end{array}$ & $\begin{array}{l}\text { Phayakkhaphum Phisai } \\
\text { Wapi Pathum } \\
\text { Na Dun } \\
\text { Yang Sisurat } \\
\text { Kut Rang } \\
\text { Chuen Chom }\end{array}$ \\
\hline Mukdahan & $\begin{array}{l}\text { Mueang Mukdahan } \\
\text { Nikhom Kham Soi } \\
\text { Don Tan } \\
\text { Dong Luang }\end{array}$ & $\begin{array}{l}\text { Khamcha-i } \\
\text { Wan Yai } \\
\text { Nong Sung }\end{array}$ \\
\hline Nakhon Phanom & $\begin{array}{l}\text { Mueang Nakhon Phanom } \\
\text { Pla Pak } \\
\text { Tha Uthen } \\
\text { Ban Phaeng } \\
\text { That Phanom } \\
\text { Renu Nakhon }\end{array}$ & $\begin{array}{l}\text { Na Kae } \\
\text { Si Songkhram } \\
\text { Na Wa } \\
\text { Phon Sawan } \\
\text { Na Thom } \\
\text { Wang Yang }\end{array}$ \\
\hline
\end{tabular}




\begin{tabular}{|c|c|c|}
\hline $\begin{array}{l}\text { Province/special } \\
\text { administrative area }\end{array}$ & Districts & \\
\hline Nakhon Ratchasima & $\begin{array}{l}\text { Mueang Nakhon } \\
\text { Ratchasima } \\
\text { Khon Buri } \\
\text { Soeng Sang } \\
\text { Khong } \\
\text { Ban Lueam } \\
\text { Chakkarat } \\
\text { Chok Chai } \\
\text { Dan Khun Thot } \\
\text { Non Thai } \\
\text { Non Sung } \\
\text { Kham Sakaesaeng } \\
\text { Bua Yai } \\
\text { Prathai } \\
\text { Pak Thong Chai } \\
\text { Phimai } \\
\text { Huai Thalaeng }\end{array}$ & $\begin{array}{l}\text { Chum Phuang } \\
\text { Sung Noen } \\
\text { Kham Thale So } \\
\text { Sikhio } \\
\text { Pak Chong } \\
\text { Nong Bun Mak } \\
\text { Kaeng Sanam Nang } \\
\text { Non Daeng } \\
\text { Wang Nam Khiao } \\
\text { Thepharak } \\
\text { Mueang Yang } \\
\text { Phra Thong Kham } \\
\text { Lam Thamenchai } \\
\text { Bua Lai } \\
\text { Sida } \\
\text { Chaloem Phra Kiat }\end{array}$ \\
\hline Nong Bua Lamphu & $\begin{array}{l}\text { Mueang Nong Bua Lam } \\
\text { Phu } \\
\text { Na Klang } \\
\text { Non Sang }\end{array}$ & $\begin{array}{l}\text { Si Bun Rueang } \\
\text { Suwannakhuha } \\
\text { Na Wang }\end{array}$ \\
\hline Nong Khai & $\begin{array}{l}\text { Mueang Nong Khai } \\
\text { Tha Bo } \\
\text { Phon Phisai } \\
\text { Si Chiang Mai } \\
\text { Sangkhom }\end{array}$ & $\begin{array}{l}\text { Sakhrai } \\
\text { Fao Rai } \\
\text { Rattanawapi } \\
\text { Pho Tak }\end{array}$ \\
\hline Roi Et & $\begin{array}{l}\text { Mueang Roi Et } \\
\text { Kaset Wisai } \\
\text { Pathum Rat } \\
\text { Chaturaphak Phiman } \\
\text { Thawat Buri } \\
\text { Phanom Phrai } \\
\text { Phon Thong } \\
\text { Pho Chai } \\
\text { Nong Phok } \\
\text { Selaphum }\end{array}$ & $\begin{array}{l}\text { Suwannaphum } \\
\text { Mueang Suang } \\
\text { Phon Sai } \\
\text { At Samat } \\
\text { Moei Wadi } \\
\text { Si Somdet } \\
\text { Changhan } \\
\text { Chiang Khwan } \\
\text { Nong Hi } \\
\text { Thung Khao Luang }\end{array}$ \\
\hline
\end{tabular}




\begin{tabular}{|c|c|c|}
\hline $\begin{array}{l}\text { Province/special } \\
\text { administrative area }\end{array}$ & \multicolumn{2}{|l|}{ Districts } \\
\hline Sakon Nakhon & $\begin{array}{l}\text { Mueang Sakon Nakhon } \\
\text { Kusuman } \\
\text { Kut Bak } \\
\text { Phanna Nikhom } \\
\text { Phang Khon } \\
\text { Waritchaphum } \\
\text { Nikhom Nam Un } \\
\text { Wanon Niwat } \\
\text { Kham Ta Kla }\end{array}$ & $\begin{array}{l}\text { Ban Muang } \\
\text { Akat Amnuai } \\
\text { Sawang Daen Din } \\
\text { Song Dao } \\
\text { Tao Ngoi } \\
\text { Khok Si Suphan } \\
\text { Charoen Sin } \\
\text { Phon Na Kaeo } \\
\text { Phu Phan }\end{array}$ \\
\hline Sisaket & $\begin{array}{l}\text { Mueang Sisaket } \\
\text { Yang Chum Noi } \\
\text { Kanthararom } \\
\text { Kantharalak } \\
\text { Khukhan } \\
\text { Phrai Bueng } \\
\text { Prang Ku } \\
\text { Khun Han } \\
\text { Rasi Salai } \\
\text { Uthumphon Phisai } \\
\text { Bueng Bun }\end{array}$ & $\begin{array}{l}\text { Huai Thap Than } \\
\text { Non Khun } \\
\text { Si Rattana } \\
\text { Nam Kliang } \\
\text { Wang Hin } \\
\text { Phu Sing } \\
\text { Mueang Chan } \\
\text { Benchalak } \\
\text { Phayu } \\
\text { Pho Si Suwan } \\
\text { Sila Lat }\end{array}$ \\
\hline Surin & $\begin{array}{l}\text { Mueang Surin } \\
\text { Chumphon Buri } \\
\text { Tha Tum } \\
\text { Chom Phra } \\
\text { Prasat } \\
\text { Kap Choeng } \\
\text { Rattanaburi } \\
\text { Sanom } \\
\text { Sikhoraphum }\end{array}$ & $\begin{array}{l}\text { Sangkha } \\
\text { Lamduan } \\
\text { Samrong Thap } \\
\text { Buachet } \\
\text { Phanom Dong Rak } \\
\text { Si Narong } \\
\text { Khwao Sinarin } \\
\text { Non Narai }\end{array}$ \\
\hline Ubon Ratchathani & $\begin{array}{l}\text { Mueang Ubon } \\
\text { Ratchathani } \\
\text { Si Mueang Mai } \\
\text { Khong Chiam } \\
\text { Khueang Nai } \\
\text { Khemarat } \\
\text { Det Udom } \\
\text { Na Chaluai } \\
\text { Nam Yuen } \\
\text { Buntharik } \\
\text { Trakan Phuet Phon } \\
\text { Kut Khaopun } \\
\text { Muang Sam Sip } \\
\text { Warin Chamrap }\end{array}$ & $\begin{array}{l}\text { Phibun Mangsahan } \\
\text { Tan Sum } \\
\text { Pho Sai } \\
\text { Samrong } \\
\text { Don Mot Daeng } \\
\text { Sirindhorn } \\
\text { Thung Si Udom } \\
\text { Na Yia } \\
\text { Na Tan } \\
\text { Lao Suea Kok } \\
\text { Sawang Wirawong } \\
\text { Nam Khun }\end{array}$ \\
\hline
\end{tabular}




\begin{tabular}{|c|c|c|}
\hline $\begin{array}{l}\text { Province/special } \\
\text { administrative area }\end{array}$ & Districts & \\
\hline Udon Thani & $\begin{array}{l}\text { Mueang Udon Thani } \\
\text { Kut Chap } \\
\text { Nong Wua So } \\
\text { Kumphawapi } \\
\text { Non Sa-at } \\
\text { Nong Han } \\
\text { Thung Fon } \\
\text { Chai Wan } \\
\text { Si That } \\
\text { Wang Sam Mo }\end{array}$ & $\begin{array}{l}\text { Ban Dung } \\
\text { Ban Phue } \\
\text { Nam Som } \\
\text { Phen } \\
\text { Sang Khom } \\
\text { Nong Saeng } \\
\text { Na Yung } \\
\text { Phibun Rak } \\
\text { Ku Kaeo } \\
\text { Prachaksinlapakhom }\end{array}$ \\
\hline Yasothon & $\begin{array}{l}\text { Mueang Yasothon } \\
\text { Sai Mun } \\
\text { Kut Chum } \\
\text { Kham Khuean Kaeo } \\
\text { Pa Tio }\end{array}$ & $\begin{array}{l}\text { Maha Chana Chai } \\
\text { Kho Wang } \\
\text { Loeng Nok Tha } \\
\text { Thai Charoen }\end{array}$ \\
\hline \multicolumn{3}{|l|}{ Northern } \\
\hline Chiang Mai & $\begin{array}{l}\text { Mueang Chiang Mai } \\
\text { Chom Thong } \\
\text { Mae Chaem } \\
\text { Chiang Dao } \\
\text { Doi Saket } \\
\text { Mae Taeng } \\
\text { Mae Rim } \\
\text { Samoeng } \\
\text { Fang } \\
\text { Mae Ai } \\
\text { Phrao } \\
\text { San Pa Tong } \\
\text { San Kamphaeng }\end{array}$ & $\begin{array}{l}\text { San Sai } \\
\text { Hang Dong } \\
\text { Hot } \\
\text { Doi Tao } \\
\text { Omkoi } \\
\text { Saraphi } \\
\text { Wiang Haeng } \\
\text { Chai Prakan } \\
\text { Mae Wang } \\
\text { Mae On } \\
\text { Doi Lo } \\
\text { Galyani Vadhana }\end{array}$ \\
\hline Chiang Rai & $\begin{array}{l}\text { Mueang Chiang Rai } \\
\text { Wiang Chai } \\
\text { Chiang Khong } \\
\text { Thoeng } \\
\text { Phan } \\
\text { Pa Daet } \\
\text { Mae Chan } \\
\text { Chiang Saen } \\
\text { Mae Sai }\end{array}$ & $\begin{array}{l}\text { Mae Suai } \\
\text { Wiang Pa Pao } \\
\text { Phaya Mengrai } \\
\text { Wiang Kaen } \\
\text { Khun Tan } \\
\text { Mae Fa Luang } \\
\text { Mae Lao } \\
\text { Wiang Chiang Rung } \\
\text { Doi Luang }\end{array}$ \\
\hline
\end{tabular}




\begin{tabular}{|c|c|c|}
\hline $\begin{array}{l}\text { Province/special } \\
\text { administrative area }\end{array}$ & Districts & \\
\hline Kamphaeng Phet & $\begin{array}{l}\text { Mueang Kamphaeng } \\
\text { Phet } \\
\text { Sai Ngam } \\
\text { Khlong Lan } \\
\text { Khanu Woralaksaburi } \\
\text { Khlong Khlung } \\
\text { Phran Kratai }\end{array}$ & $\begin{array}{l}\text { Lan Krabue } \\
\text { Sai Thong Watthana } \\
\text { Pang Sila Thong } \\
\text { Bueng Samakkhi } \\
\text { Kosamphi Nakhon }\end{array}$ \\
\hline Lampang & $\begin{array}{l}\text { Mueang Lampang } \\
\text { Mae Mo } \\
\text { Ko Kha } \\
\text { Soem Ngam } \\
\text { Ngao } \\
\text { Chae Hom } \\
\text { Wang Nuea }\end{array}$ & $\begin{array}{l}\text { Thoen } \\
\text { Mae Phrik } \\
\text { Mae Tha } \\
\text { Sop Prap } \\
\text { Hang Chat } \\
\text { Mueang Pan }\end{array}$ \\
\hline Lamphun & $\begin{array}{l}\text { Mueang Lamphun } \\
\text { Mae Tha } \\
\text { Ban Hong } \\
\text { Li } \\
\end{array}$ & $\begin{array}{l}\text { Thung Hua Chang } \\
\text { Pa Sang } \\
\text { Ban Thi } \\
\text { Wiang Nong Long }\end{array}$ \\
\hline Mae Hong Son & $\begin{array}{l}\text { Mae Hong Son } \\
\text { Khun Yuam } \\
\text { Pai } \\
\text { Mae Sariang }\end{array}$ & $\begin{array}{l}\text { Mae La Noi } \\
\text { Sop Moei } \\
\text { Pang Mapha }\end{array}$ \\
\hline Nakhon Sawan & $\begin{array}{l}\text { Mueang Nakhon Sawan } \\
\text { Krok Phra } \\
\text { Chum Saeng } \\
\text { Nong Bua } \\
\text { Banphot Phisai } \\
\text { Kao Liao } \\
\text { Takhli } \\
\text { Tha Tako }\end{array}$ & $\begin{array}{l}\text { Phaisali } \\
\text { Phayuha Khiri } \\
\text { Lat Yao } \\
\text { Tak Fa } \\
\text { Mae Wong } \\
\text { Mae Poen } \\
\text { Chum Ta Bong }\end{array}$ \\
\hline Nan & $\begin{array}{l}\text { Mueang Nan } \\
\text { Mae Charim } \\
\text { Ban Luang } \\
\text { Na Noi } \\
\text { Pua } \\
\text { Tha Wang Pha } \\
\text { Wiang Sa } \\
\text { Thung Chang } \\
\end{array}$ & $\begin{array}{l}\text { Chiang Klang } \\
\text { Na Muen } \\
\text { Santi Suk } \\
\text { Bo Kluea } \\
\text { Song Khwae } \\
\text { Phu Phiang } \\
\text { Chaloem Phra Kiat }\end{array}$ \\
\hline Phayao & $\begin{array}{l}\text { Mueang Phayao } \\
\text { Chun } \\
\text { Chiang Kham } \\
\text { Chiang Muan } \\
\text { Dok Khamtai }\end{array}$ & $\begin{array}{l}\text { Pong } \\
\text { Mae Chai } \\
\text { Phu Sang } \\
\text { Phu Kamyao }\end{array}$ \\
\hline
\end{tabular}




\begin{tabular}{|c|c|c|}
\hline $\begin{array}{l}\text { Province/special } \\
\text { administrative area }\end{array}$ & Districts & \\
\hline Phetchabun & $\begin{array}{l}\text { Mueang Phetchabun } \\
\text { Chon Daen } \\
\text { Lom Sak } \\
\text { Lom Kao } \\
\text { Wichian Buri } \\
\text { Si Thep }\end{array}$ & $\begin{array}{l}\text { Nong Phai } \\
\text { Bueng Sam Phan } \\
\text { Nam Nao } \\
\text { Wang Pong } \\
\text { Khao Kho }\end{array}$ \\
\hline Phichit & $\begin{array}{l}\text { Mueang Phichit } \\
\text { Wang Sai Phun } \\
\text { Pho Prathap Chang } \\
\text { Taphan Hin } \\
\text { Bang Mun Nak } \\
\text { Pho Thale }\end{array}$ & $\begin{array}{l}\text { Sam Ngam } \\
\text { Tap Khlo } \\
\text { Sak Lek } \\
\text { Bueng Na Rang } \\
\text { Dong Charoen } \\
\text { Wachirabarami }\end{array}$ \\
\hline Phitsanulok & $\begin{array}{l}\text { Mueang Phitsanulok } \\
\text { Nakhon Thai } \\
\text { Chat Trakan } \\
\text { Bang Rakam } \\
\text { Bang Krathum }\end{array}$ & $\begin{array}{l}\text { Phrom Phiram } \\
\text { Wat Bot } \\
\text { Wang Thong } \\
\text { Noen Maprang }\end{array}$ \\
\hline Phrae & $\begin{array}{l}\text { Mueang Phrae } \\
\text { Rong Kwang } \\
\text { Long } \\
\text { Sung Men }\end{array}$ & $\begin{array}{l}\text { Den Chai } \\
\text { Song } \\
\text { Wang Chin } \\
\text { Nong Muang Khai }\end{array}$ \\
\hline Sukhothai & $\begin{array}{l}\text { Mueang Sukhothai } \\
\text { Ban Dan Lan Hoi } \\
\text { Khiri Mat } \\
\text { Kong Krailat } \\
\text { Si Satchanalai }\end{array}$ & $\begin{array}{l}\text { Si Samrong } \\
\text { Sawankhalok } \\
\text { Si Nakhon } \\
\text { Thung Saliam }\end{array}$ \\
\hline Tak & \begin{tabular}{|l} 
Mueang Tak \\
Ban Tak \\
Sam Ngao \\
Mae Ramat \\
Tha Song Yang \\
\end{tabular} & $\begin{array}{l}\text { Mae Sot } \\
\text { Phop Phra } \\
\text { Umphang } \\
\text { Wang Chao }\end{array}$ \\
\hline Uthai Thani & $\begin{array}{l}\text { Mueang Uthai Thani } \\
\text { Thap Than } \\
\text { Sawang Arom } \\
\text { Nong Chang }\end{array}$ & $\begin{array}{l}\text { Nong Khayang } \\
\text { Ban Rai } \\
\text { Lan Sak } \\
\text { Huai Khot }\end{array}$ \\
\hline Uttaradit & $\begin{array}{l}\text { Mueang Uttaradit } \\
\text { Tron } \\
\text { Tha Pla } \\
\text { Nam Pat } \\
\text { Fak Tha }\end{array}$ & $\begin{array}{l}\text { Ban Khok } \\
\text { Phichai } \\
\text { Laplae } \\
\text { Thong Saen Khan }\end{array}$ \\
\hline
\end{tabular}




\begin{tabular}{|c|c|c|}
\hline $\begin{array}{l}\text { Province/special } \\
\text { administrative area }\end{array}$ & \multicolumn{2}{|l|}{ Districts } \\
\hline \multicolumn{3}{|l|}{ Southern } \\
\hline Chumphon & $\begin{array}{l}\text { Mueang Chumphon } \\
\text { Tha Sae } \\
\text { Pathio } \\
\text { Lang Suan }\end{array}$ & $\begin{array}{l}\text { Lamae } \\
\text { Phato } \\
\text { Sawi } \\
\text { Thung Tako }\end{array}$ \\
\hline Krabi & $\begin{array}{l}\text { Mueang Krabi } \\
\text { Khao Phanom } \\
\text { Ko Lanta } \\
\text { Khlong Thom }\end{array}$ & $\begin{array}{l}\text { Ao Luek } \\
\text { Plai Phraya } \\
\text { Lam Thap } \\
\text { Nuea Khlong }\end{array}$ \\
\hline $\begin{array}{l}\text { Nakhon Si } \\
\text { Thammarat }\end{array}$ & $\begin{array}{l}\text { Mueang Nakhon Si } \\
\text { Thammarat } \\
\text { Phrom Khiri } \\
\text { Lan Saka } \\
\text { Chawang } \\
\text { Phipun } \\
\text { Chian Yai } \\
\text { Cha-uat } \\
\text { Tha Sala } \\
\text { Thung Song } \\
\text { Na Bon } \\
\text { Thung Yai } \\
\text { Pak Phanang }\end{array}$ & $\begin{array}{l}\text { Ron Phibun } \\
\text { Sichon } \\
\text { Khanom } \\
\text { Hua Sai } \\
\text { Bang Khan } \\
\text { Tham Phannara } \\
\text { Chulabhorn } \\
\text { Phra Phrom } \\
\text { Nopphitam } \\
\text { Chang Klang } \\
\text { Chaloem Phra Kiat }\end{array}$ \\
\hline Narathiwat & $\begin{array}{l}\text { Mueang Narathiwat } \\
\text { Tak Bai } \\
\text { Bacho } \\
\text { Yi-ngo } \\
\text { Ra-ngae } \\
\text { Rueso } \\
\text { Si Sakhon }\end{array}$ & $\begin{array}{l}\text { Waeng } \\
\text { Sukhirin } \\
\text { Su-ngai Kolok } \\
\text { Su-ngai Padi } \\
\text { Chanae } \\
\text { Cho-airong }\end{array}$ \\
\hline Pattani & $\begin{array}{l}\text { Mueang Pattani } \\
\text { Khok Pho } \\
\text { Nong Chik } \\
\text { Panare } \\
\text { Mayo } \\
\text { Thung Yang Daeng }\end{array}$ & $\begin{array}{l}\text { Sai Buri } \\
\text { Mai Kaen } \\
\text { Yaring } \\
\text { Yarang } \\
\text { Kapho } \\
\text { Mae Lan }\end{array}$ \\
\hline Phang Nga & $\begin{array}{l}\text { Mueang Phang Nga } \\
\text { Ko Yao } \\
\text { Kapong } \\
\text { Takua Thung }\end{array}$ & $\begin{array}{l}\text { Takua Pa } \\
\text { Khura Buri } \\
\text { Thap Put } \\
\text { Thai Mueang }\end{array}$ \\
\hline
\end{tabular}




\begin{tabular}{|c|c|c|}
\hline $\begin{array}{l}\text { Province/special } \\
\text { administrative area }\end{array}$ & Districts & \\
\hline Phattalung & $\begin{array}{l}\text { Mueang Phatthalung } \\
\text { Kong Ra } \\
\text { Khao Chaison } \\
\text { Tamot } \\
\text { Khuan Khanun } \\
\text { Pak Phayun }\end{array}$ & $\begin{array}{l}\text { Si Banphot } \\
\text { Pa Bon } \\
\text { Bang Kaeo } \\
\text { Pa Phayom } \\
\text { Srinagarindra }\end{array}$ \\
\hline Phuket & $\begin{array}{l}\text { Mueang Phuket } \\
\text { Kathu }\end{array}$ & Thalang \\
\hline Ranong & $\begin{array}{l}\text { Mueang Ranong } \\
\text { La-un } \\
\text { Kapoe }\end{array}$ & $\begin{array}{l}\text { Kra Buri } \\
\text { Suk Samran }\end{array}$ \\
\hline Satun & $\begin{array}{l}\text { Mueang Satun } \\
\text { Khuan Don } \\
\text { Khuan Kalong } \\
\text { Tha Phae }\end{array}$ & $\begin{array}{l}\text { La-ngu } \\
\text { Thung Wa } \\
\text { Manang }\end{array}$ \\
\hline Songkhla & $\begin{array}{l}\text { Mueang Songkhla } \\
\text { Sathing Phra } \\
\text { Chana } \\
\text { Na Thawi } \\
\text { Thepha } \\
\text { Saba Yoi } \\
\text { Ranot } \\
\text { Krasae Sin } \\
\end{array}$ & $\begin{array}{l}\text { Rattaphum } \\
\text { Sadao } \\
\text { Hat Yai } \\
\text { Na Mom } \\
\text { Khuan Niang } \\
\text { Bang Klam } \\
\text { Singhanakhon } \\
\text { Khlong Hoi Khong }\end{array}$ \\
\hline Surat Thani & $\begin{array}{l}\text { Mueang Surat Thani } \\
\text { Kanchanadit } \\
\text { Don Sak } \\
\text { Ko Samui } \\
\text { Ko Pha-ngan } \\
\text { Chaiya } \\
\text { Tha Chana } \\
\text { Khiri Rat Nikhom } \\
\text { Ban Ta Khun } \\
\text { Phanom }\end{array}$ & $\begin{array}{l}\text { Tha Chang } \\
\text { Ban Na San } \\
\text { Ban Na Doem } \\
\text { Khian Sa } \\
\text { Wiang Sa } \\
\text { Phrasaeng } \\
\text { Phunphin } \\
\text { Chai Buri } \\
\text { Vibhavadi }\end{array}$ \\
\hline Trang & $\begin{array}{l}\text { Mueang Trang } \\
\text { Kantang } \\
\text { Yan Ta Khao } \\
\text { Palian } \\
\text { Sikao } \\
\end{array}$ & $\begin{array}{l}\text { Huai Yot } \\
\text { Wang Wiset } \\
\text { Na Yong } \\
\text { Ratsada } \\
\text { Hat Samran }\end{array}$ \\
\hline Yala & $\begin{array}{l}\text { Mueang Yala } \\
\text { Betong } \\
\text { Bannang Sata } \\
\text { Than To }\end{array}$ & $\begin{array}{l}\text { Yaha } \\
\text { Raman } \\
\text { Kabang } \\
\text { Krong Pinang }\end{array}$ \\
\hline
\end{tabular}


120 | THE MRC WRITING, PUBLICATION \& STYLE GUIDE

\begin{tabular}{|c|c|c|}
\hline $\begin{array}{l}\text { Province/special } \\
\text { administrative area }\end{array}$ & \multicolumn{2}{|l|}{ Districts } \\
\hline \multicolumn{3}{|l|}{ Western } \\
\hline Kanchanaburi & $\begin{array}{l}\text { Mueang Kanchanaburi } \\
\text { Sai Yok } \\
\text { Bo Phloi } \\
\text { Si Sawat } \\
\text { Tha Maka } \\
\text { Tha Muang } \\
\text { Thong Pha Phum }\end{array}$ & $\begin{array}{l}\text { Sangkhla Buri } \\
\text { Phanom Thuan } \\
\text { Lao Khwan } \\
\text { Dan Makham Tia } \\
\text { Nong Prue } \\
\text { Huai Krachao }\end{array}$ \\
\hline Phetchaburi & $\begin{array}{l}\text { Mueang Phetchaburi } \\
\text { Khao Yoi } \\
\text { Nong Ya Plong } \\
\text { Cha-am }\end{array}$ & $\begin{array}{l}\text { Tha Yang } \\
\text { Ban Lat } \\
\text { Ban Laem } \\
\text { Kaeng Krachan }\end{array}$ \\
\hline Prachuap Khiri Khan & $\begin{array}{l}\text { Mueang Prachuap Khiri } \\
\text { Khan } \\
\text { Kui Buri } \\
\text { Thap Sakae } \\
\text { Bang Saphan }\end{array}$ & $\begin{array}{l}\text { Bang Saphan Noi } \\
\text { Pran Buri } \\
\text { Hua Hin } \\
\text { Sam Roi Yot }\end{array}$ \\
\hline Ratchaburi & $\begin{array}{l}\text { Mueang Ratchaburi } \\
\text { Chom Bueng } \\
\text { Suan Phueng } \\
\text { Damnoen Saduak } \\
\text { Ban Pong }\end{array}$ & $\begin{array}{l}\text { Bang Phae } \\
\text { Photharam } \\
\text { Pak Tho } \\
\text { Wat Phleng } \\
\text { Ban Kha }\end{array}$ \\
\hline Samut Songkhram & $\begin{array}{l}\text { Mueang Samut } \\
\text { Songkhram } \\
\text { Bang Khonthi }\end{array}$ & Amphawa \\
\hline Suphan Buri & $\begin{array}{l}\text { Mueang Suphan Buri } \\
\text { Doem Bang Nang Buat } \\
\text { Dan Chang } \\
\text { Bang Pla Ma } \\
\text { Si Prachan }\end{array}$ & $\begin{array}{l}\text { Don Chedi } \\
\text { Song Phi Nong } \\
\text { Sam Chuk } \\
\text { U Thong } \\
\text { Nong Ya Sai }\end{array}$ \\
\hline
\end{tabular}




\section{Viet Nam}

\begin{tabular}{|c|c|}
\hline Province/city & Administrative centre \\
\hline \multicolumn{2}{|l|}{ Northeast } \\
\hline Bac Giang & Bac Giang City \\
\hline Bac Kan & Bac Kan City \\
\hline Cao Bang & Cao Bang City \\
\hline Ha Giang & Ha Giang City \\
\hline Lang Son & Lang Son City \\
\hline Phu Tho & Viet Tri \\
\hline Quang Ninh & Ha Long \\
\hline Thai Nguyen & Thai Nguyen City \\
\hline Tuyen Quang & Tuyen Quang City \\
\hline \multicolumn{2}{|l|}{ Northwest } \\
\hline Dien Bien & Dien Bien Phu \\
\hline Hoa Binh & Hoa Binh City \\
\hline Lai Chau & Lai Chau City \\
\hline Lao Cai & Lao Cai City \\
\hline Son La & Son La City \\
\hline Yen Bai & Yen Bai City \\
\hline \multicolumn{2}{|l|}{ Red River Delta } \\
\hline Bac Ninh & Bac Ninh City \\
\hline Ha Nam & Phu Ly \\
\hline Ha Noi & Hoan Kiem District \\
\hline Hai Duong & Hai Duong City \\
\hline Hai Phong & Hong Bang District \\
\hline Hung Yen & Hung Yen City \\
\hline Nam Dinh & Nam Dinh City \\
\hline Ninh Binh & Ninh Binh City \\
\hline Thai Binh & Thai Binh City \\
\hline Vinh Phuc & Vinh Yen \\
\hline \multicolumn{2}{|c|}{ North Central Coast } \\
\hline Ha Tinh & Ha Tinh City \\
\hline Nghe An & Vinh \\
\hline Quang Binh & Dong Hoi \\
\hline Quang Tri & Dong $\mathrm{Ha}$ \\
\hline Thanh Hoa & Thanh Hoa City \\
\hline Thua ThienHue & Hue \\
\hline
\end{tabular}


122 | THE MRC WRITING, PUBLICATION \& STYLE GUIDE

\begin{tabular}{|c|c|}
\hline Province/city & Administrative centre \\
\hline \multicolumn{2}{|l|}{ Central Highland } \\
\hline Dak Lak & Buon Ma Thuot \\
\hline Dak Nong & Gia Nghia \\
\hline Gia Lai & Pleiku \\
\hline Kon Tum & Kon Tum City \\
\hline Lam Dong & Da Lat \\
\hline \multicolumn{2}{|c|}{ South Central Coast } \\
\hline Binh Dinh & Quy Nhon \\
\hline Binh Thuan & Phan Thiet \\
\hline Da Nang & Hai Chau District \\
\hline Khanh Hoa & Nha Trang \\
\hline Ninh Thuan & Phan Rang - Thap Cham \\
\hline Phu Yen & Tuy Hoa \\
\hline Quang Nam & Tam Ky \\
\hline Quang Ngai & Quang Ngai City \\
\hline \multicolumn{2}{|l|}{ Southeast } \\
\hline Ba Ria - Vung Tau & Ba Ria \\
\hline Binh Duong & Thu Dau Mot \\
\hline Binh Phuoc & Dong Xoai \\
\hline Dong Nai & Bien Hoa \\
\hline Ho Chi Minh & District 1 \\
\hline Tay Ninh & Tay Ninh City \\
\hline \multicolumn{2}{|l|}{ Mekong Delta } \\
\hline An Giang & Long Xuyen \\
\hline Bac Lieu & Bac Lieu City \\
\hline Ben Tre & Ben Tre City \\
\hline Ca Mau & Ca Mau City \\
\hline Can Tho & Ninh Kieu District \\
\hline Dong Thap & Cao Lanh \\
\hline Hau Giang & Vi Thanh \\
\hline Kien Giang & Rach Gia \\
\hline Long An & Tan An \\
\hline Soc Trang & Soc Trang City \\
\hline Tien Giang & My Tho \\
\hline Tra Vinh & Tra Vinh City \\
\hline Vinh Long & Vinh Long City \\
\hline
\end{tabular}




\section{Rivers and catchments}

These are the catchment areas of tributary rivers draining into the Mekong River. A total of 104 catchments have been delineated as part of the Watershed Classification Project which was completed by the MRC in 2001. The name of these catchments usually reflects the name of the largest of the rivers where they are located.

\begin{tabular}{|l|l|l|}
\hline Name of river and catchment & Nam Khan & Nam Thong \\
\hline Ban Khai San & Nam Khop & Nam Ton \\
\hline Belta & Nam Loei & O Talas \\
\hline Doi Luang Pae Muang & Nam Ma & Phu Luong Yot Huai Dua \\
\hline Huai Khok & Nam Mae Ing & Phu Pa Huak \\
\hline Huai Bang Bot & Nam Mae Kham & Prek Chhlong \\
\hline Huai Bang Koi & Nam Mae Kok & Prek Kamp \\
\hline Huai Ma Hiao & Nam Mae Ngao & Prek Krieng \\
\hline Huai Nam Huai & Nam Mang & Prek Mun \\
\hline Huai Sophay & Nam Mang Ngai & Prek Preah \\
\hline Hoaag Hua & Nam Mi & Prek Te \\
\hline Huai Bang Haak & Nam Mun & Prek Thnot \\
\hline Huai Bang I & Nam Nago & Se Bang Fai \\
\hline Huai Bang Lieng & Nam Ngam & Se Bang Hieng \\
\hline Huai Bang Sai & Nam Ngaou & Se Bang Nouan \\
\hline Huai Ho & Nam Ngeun & Se Don \\
\hline Huai Khamouan & Nam Ngum & Se Kong \\
\hline Huai Luang & Nam Nhah & Se San \\
\hline Huai Mong & Nam Nhiam & Siem Bok \\
\hline Huai Muk & Nam Nhiep & Sre Pok \\
\hline Huai Nam Som & Nam Nuao & Steung Baribo \\
\hline Huai Som Pak & Nam Ou & Steung Battambang \\
\hline Huai Thuai & Nam Pho & Steung Chikreng \\
\hline Huai Tomo & Nam Phone & Steung Chinit \\
\hline Muang Liep & Nam Phoul & Steung Dauntri \\
\hline Nam Beng & Steung Mongkol Borey \\
\hline Nam Cadinh & Steung Pursat \\
\hline Nam Chi & Steung Sangker \\
\hline
\end{tabular}


124 | THE MRC WRITING, PUBLICATION \& STYLE GUIDE

\begin{tabular}{|l|l|l|}
\hline Nam Heung & Nam Sing & Steung Sen \\
\hline Nam Hinboun & Nam Songkhram & Steung Siem Reap \\
\hline Nam Houng & Nam Suai & Steung Sreng \\
\hline Nam Kadun & Nam Suong & Steung Staung \\
\hline Nam Kai & Nam Tam & Tonle Repon \\
\hline Nam Kam & Nam Tha & Tonle Sap \\
\hline Nam Keung & Nam Thon & \\
\hline
\end{tabular}




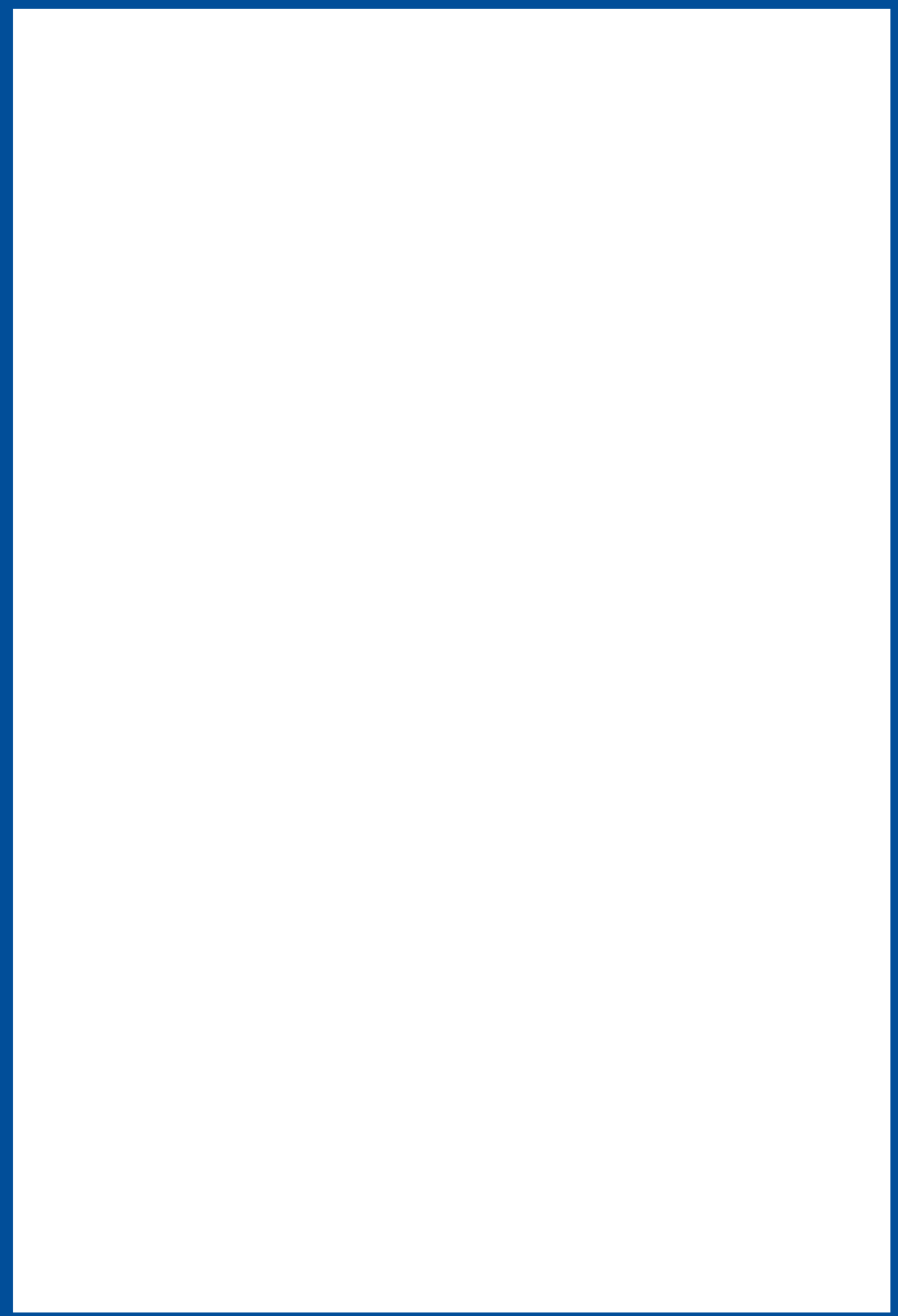



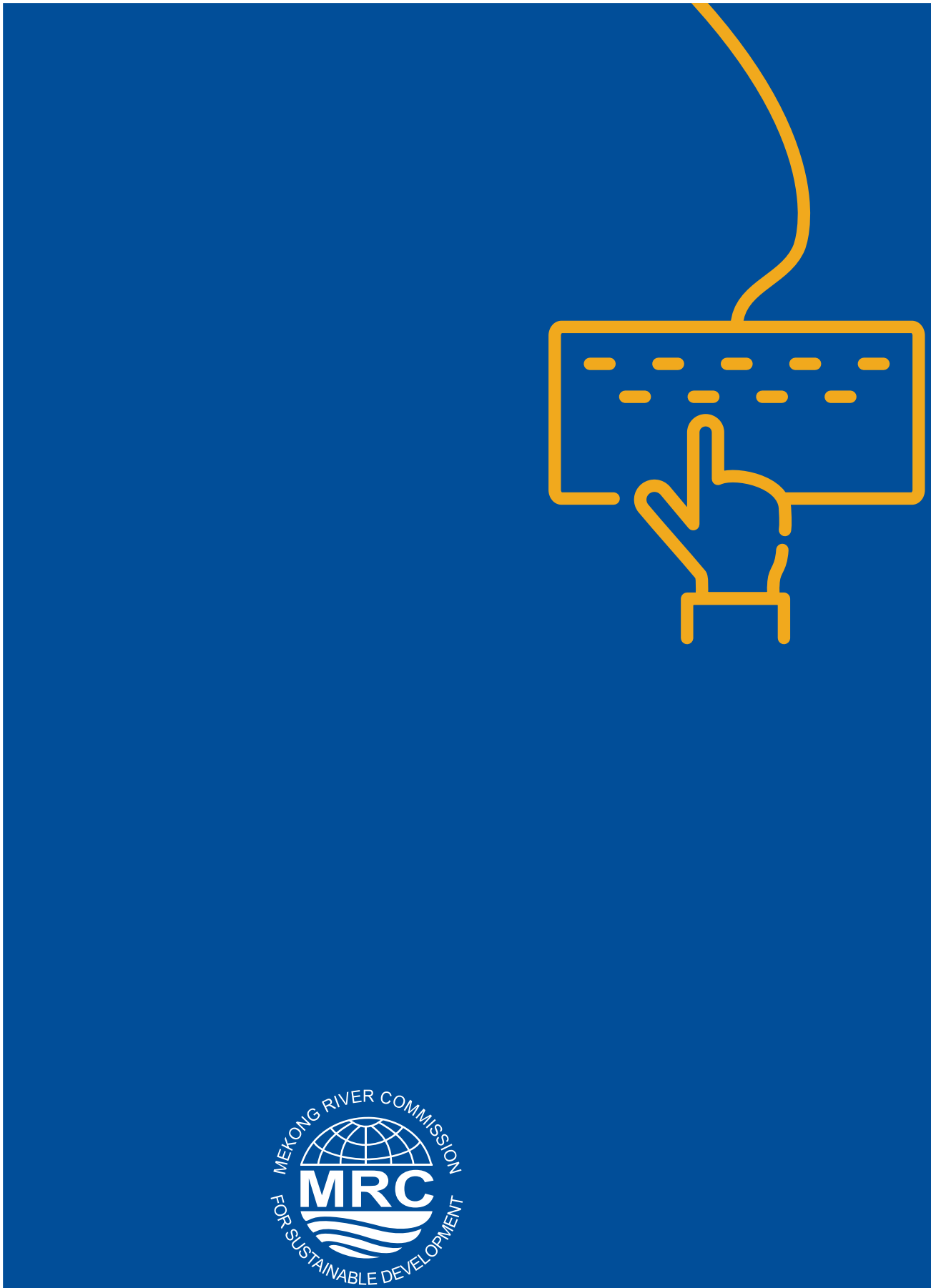

Mekong River Commission

November 2021 